UNIVERSIDADE DE SÃO PAULO

Instituto de Química

\title{
Desenvolvimento de metodologia analítica para a determinação de indicador biológico de exposição ao benzeno
}

MAURICIO XAVIER COUTRIM

Tese de doutorado

Profa. Dra. LILIAN R. F. DE CARVALHO

Orientadora

São Paulo 
"Desenvolvimento de Metodologia Analítica para a

Determinação de Indicador Biológico de Exposição ao Benzeno"

\section{MAURICIO XAVIER COUTRIM}

Tese de Doutorado submetida ao Instituto de Química da Universidade de São Paulo como parte dos requisitos necessários à obtenção do grau de Doutor em Ciências - Área: Química Analítica

Aprovado por:

Profa. Dra. LILIAN ROTHSCHILD FRANCO DE CARVALHO

IQ - USP

(Orientadora e Presidente)

\begin{tabular}{|c|}
\hline $\begin{array}{l}\text { Profa. Dra. NINA COICHEV } \\
\text { IQ - USP }\end{array}$ \\
\hline $\begin{array}{l}\text { Prof. Dr. SÉRGIO MASSARO } \\
\text { IQ - USP }\end{array}$ \\
\hline $\begin{array}{l}\text { Profa. Dra. ISABEL CRISTINA SALES FONTES JARDIM } \\
\text { IQ - UNICAMP }\end{array}$ \\
\hline $\begin{array}{l}\text { Profa. Dra. ARLINE SYDNÉIA ABEL ARCURI } \\
\text { FUNDACENTRO }\end{array}$ \\
\hline $\begin{array}{c}\text { SÃO PAULO } \\
\text { 08 DE OUTUBRO DE } 1998\end{array}$ \\
\hline
\end{tabular}


À quem colocoume no mundo dando-me a base para a integridade: Joana e Xavier

\author{
À Esperança que \\ transborda na infância \\ de Mayara e Renato
}

“...Non siamo angeli in volo venuti dal cielo, ma gente comune che ama davvero, gente che vuole un mondo più vero..." (1) À Flor que assim comigo vive:

Rosa 


\section{AGRADECIMENTOS}

- À Deus pela vida e, em particular, pela proteção durante os $120000 \mathrm{Km}$ percorridos na via Dutra para chegar até aqui.

- À Profa. Dra. Lilian R. F. de Carvalho pela orientação, a qual foi além dos campos da ciência, e pela paciência demonstrada principalmente na fase final da redação. Sua amizade foi importante na caminhada.

- À Dra. Arline S. A. Arcuri pelo envolvimento na elaboração do projeto, pelo estímulo e amizade.

- Ao pessoal do LEMA, dos recém chegados aos que por lá já passaram, incluindo os adotivos, pelo companheirismo, alegria, convivência pacífica e pelos momentos de descontração ao redor dos bolos da mãe da Denise. Tudo isto certamente deixará saudades. Para não ser injusto mencionarei os nomes por ordem alfabética: Alessandra Shimizo, Andrea, Bruno, Célia, Denise, Gisele, Heliara, Jorge, Larisse, Liliam, Pérola, Renato, Sílvia, Simone, Sonia e Wilson.

- À Profa. Dra. Marina F. M. Tavares pela iniciação na técnica de eletroforese capilar e pelas discussões sempre proveitosas.

- À Alessandra Jager pela valiosa ajuda durante a realização de boa parte do trabalho experimental.

- À minha grande família: irmãos, sogros, cunhados e sobrinhos que estiveram sempre tão perto dando a maior força nos bastidores.

- À todos os professores, principalmente da química analítica, funcionários da Biblioteca, xerox, portaria, secretarias da analítica e da pós-graduação, colegas pós-graduandos, enfim todos que de alguma forma colaboraram para a realização deste trabalho.

- À FUNDACENTRO pelo suporte técnico e fornecimento de materiais. À Luiza e Luzia por ajudarem em diversos momentos.

- Ao CNPq pelo auxílio financeiro recebido e à FAPESP pelo equipamento de eletroforese capilar.

- Um agradecimento especial aos anônimos que colaboraram com a doação de urina, fundamental para o desenrolar da pesquisa. 


\section{SUMÁRIO}

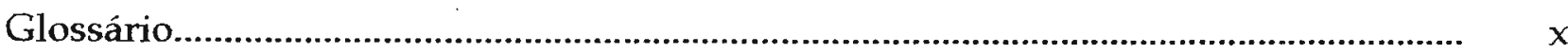

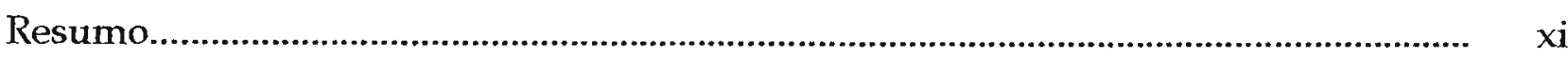

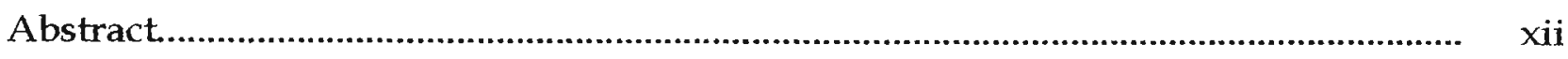

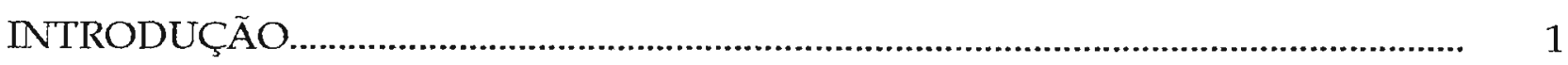

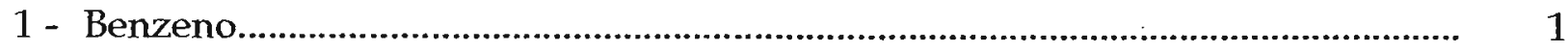

1.1 - Histórico da exposição ocupacional ao benzeno..................................... 2

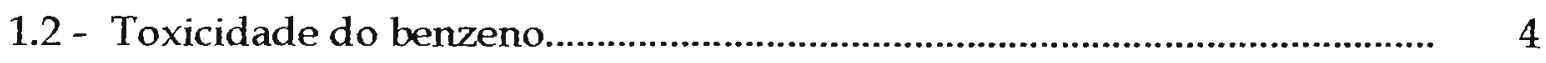

1.3 - Benzeno no Brasil................................................................................ 5

1.3.1 - As legislações relacionadas ao benzeno............................................ 6

1.4 - Benzeno como poluente em ambiente não ocupacional............................ 8

2 - Indicadores biológicos de exposição................................................................ 10

2.1 - Metabolismo do benzeno................................................................... 12

2.2 - Indicadores biológicos de exposição ao benzeno........................................ 14

2.2.1 - Ácido trans, trans-mucônico urinário............................................. 17

2.2.2 - Ácido S-fenilmercaptúrico urinário............................................. 21

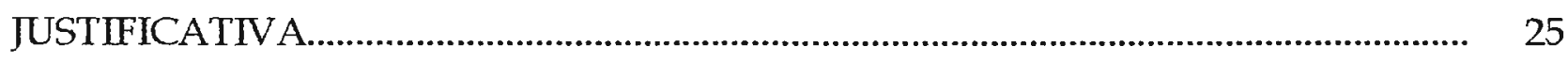

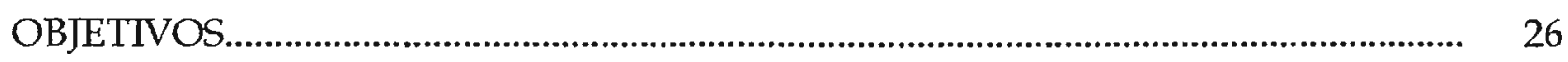

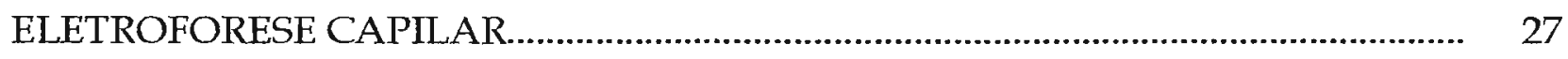

1 - Princípios básicos da técnica.......................................................................... 27

2 - Determinação de ânions de baixa massa molar em matriz biológica por eletroforese capilar............................................................................................ 34

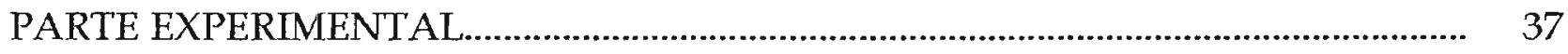

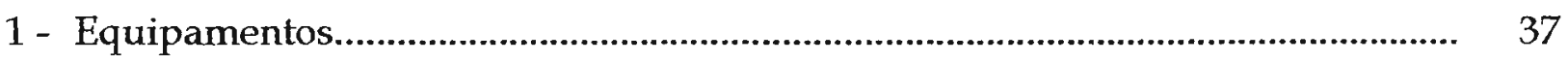

1.1 - Equipamento de cromatografia líquida de alta eficiência com detector de UV-visível (HPLC-UV). 
1.2 - Equipamento de eletroforese capilar com detector de UV-visível (CE-UV).

1.3 - Equipamento de extração.

1.4 - Equipamento de cromatografia a gás com detector de ionização em chama (GC-FID).

1.5 - Equipamento de ultra-som.

1.6 - Equipamento de espectrofotometria.

1.7 - Medidor de $\mathrm{pH}$

1.8 - Balança analítica

2 - Reagentes.

3 - Soluções utilizadas.

3.1 - Preparação das soluções.

3.1.1 - Ácido trans, trans-mucônico (AM) $10 \mathrm{mg} / \mathrm{L}$ (solução padrão).

3.1 .2 - Ácido S-fenilmercaptúrico (AFM) $100 \mathrm{mg} / \mathrm{L}$ (solução padrão).

3.1.3 - Brometo de cetiltrimetilamônio (CTAB) $4 \mathrm{mmol} / \mathrm{L}$ (solução estoque).

3.1.4 - Fosfato de sódio $300 \mathrm{mmol} / \mathrm{L}$, tampão pH 7,0 (solução estoque).

4 - Avaliação da determinação de benzeno por HPLC-UV e por GC-FID.

5 - Coleta e armazenamento de urina.

6 - Determinação qualitativa e quantitativa.

6.1 - Método da calibração externa.

6.2 - Método da adição de padrão.

6.3 - Limite de detecção (LD).

7 - Determinaçāo de AM em amostras de urina humana por HPLC-UV 
7.2 - Extração de AM com éter dietílico.

7.3 - Extração de AM através de cartuchos contendo SAX................................ 50

7.4 - Avaliação das colunas analíticas.............................................................. 50

7.5 - Determinações de AM em amostras de urina com a coluna Ultrasphere ODS.

7.6 - Determinações de AM em amostras de urina com a coluna Hibar® RT 250-4.

8 - Desenvolvimentos de metodologia para a determinação de AM em urina humana por $\mathrm{CE}$, sem a utilização de modificador orgânico.

8.1 - Comprimento de onda de máxima absorção.

8.2 - Composição do eletrólito

8.3 - Capilar.

8.4 - Sistema de injeção.

8.5 - Temperatura e voltagem aplicadas.

8.6 - Repetibilidade e recuperação do método

8.7 - Determinação de AM em amostras de urina.

9 - Desenvolvimentos de metodologia para a determinação de AM em urina humana por CE com a utilização de modificador orgânico.

9.1 - Escolha do modificador orgânico.

9.2 - Repetibilidade das injeções de amostra.

9.3 - Recuperação do método.

9.4 - Determinação de AM em amostras de urina.

10 - Determinação de ácido S-fenilmercaptúrico (AFM) em amostras de urina humana por $\mathrm{CE}$

10.1 - Separação de AFM da urina sem extração prévia.

10.2 - Separação de AFM extraído da urina com Sep-Pak C18.

10.3 - Separação de AFM extraído da urina com resina SAX. 
1 - Avaliação da determinação de benzeno por HPLC-UV e por GC-FID............... 61

1.1 - Avaliação da sensibilidade da detecção do benzeno por HPLC-UV........ 61

1.2 - Avaliação da sensibilidade da detecção do benzeno por GC-FID............. 61

2 - Coleta de urina de indivíduos fumantes e não fumantes.................................. 62

3 - Determinação de AM em amostras de urina humana por HPLC-UV................ 63

3.1 - Extração do AM de amostras de urina..................................................... 66

3.2 - Determinação da concentração de creatinina nas amostras de urina........ 70

3.3 - Determinação de AM urinário com eluição isocrática.............................. 72

3.4 - Determinação de AM urinário com eluição isocrática em amostras com teores de creatinina conhecidos....................................................... 74

3.5 - Determinação de AM urinário com eluição por gradiente em amostras com teores de creatinina conhecidos........................................... $\quad 76$

3.6 - Comparação de resultados de concentrações de AM urinário por HPLC.

4 - Desenvolvimento de metodologia para a determinação de AM em amostras de urina humana por $\mathrm{CE}$.

4.1 - Determinação de AM urinário sem utilização de modificador orgânico.. 81

4.1.1 - Avaliação das condições analíticas................................................ 81

4.1.1.1 - Capilar....................................................................... 82

4.1.1.2 - Tampão................................................................. 82

4.1 .1 .3 - Voltagem................................................................... 83

4.1.1.4 - Temperatura.................................................................... 83

4.1.1.5 - Introdução da amostra................................................... 84

4.1.2 - Determinação qualitativa............................................................ 89

4.1 .3 - Repetibilidade............................................................................... 90

4.1 .4 - Recuperação................................................................................ 91

4.1 .5 - Determinação quantitativa................................................................ 92 
4.2 - Determinação de AM urinário com adição de modificador orgânico ao eletrólito.

4.2.1 - Avaliação da adição do modificador orgânico ao eletrólito

4.2.2 - Determinação qualitativa............................................................... 96

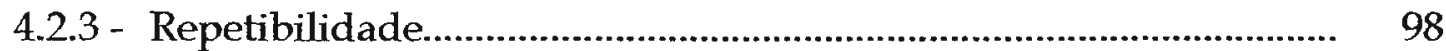

4.2 .4 - Recuperação.............................................................................. 100

4.2 .5 - Determinação quantitativa............................................................ 101

4.2.6 - Avaliação das medidas de AM urinário........................................ 108

4.3 - Comparação entre as concentrações de AM urinário determinados com e sem uso de metanol....................................................................... 108

5 - Grupos de fumantes e não fumantes diferenciados pelo AM urinário.............. 110

5.1 - Diferenciação entre não fumantes, fumantes passivos e fumantes pelo número de cigarros através do AM urinário..................... 113

6 - Comparação entre HPLC e CE na determinação de AM urinário........................ 113

7 - Avaliação das condições analíticas para a determinação de AFM em amostras de urina humana por $\mathrm{CE}$.

7.1 - Avaliação da separação de AFM urinário por CE-UV

CONCLUSĀO.

SUGESTÕES PARA TRABALHOS FUTUROS.

REFERÊNCIAS BIBLIOGRÁFICAS..................................................................... 122

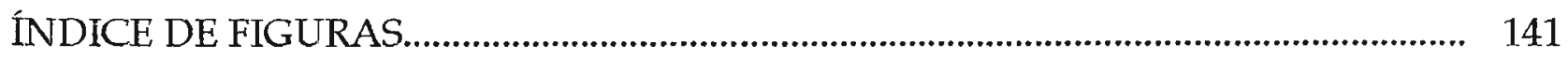

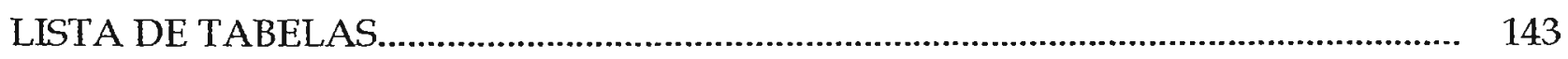

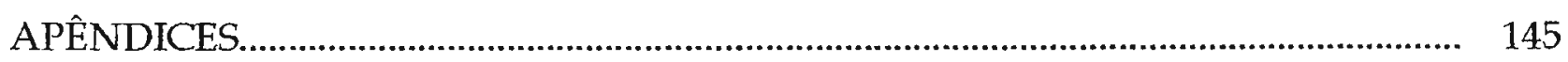

I - Determinação do teor de creatinina em amostras de urina...................... 145

II - Questionário e ficha de controle das amostras de urina.......................... 147

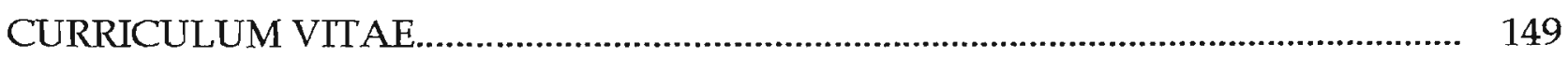




\section{GLOSSÁRIO}

ACGIH

AFM

AM

BEI

$\mathrm{CE}$

CTAB

DMF

FID

FUNDACENTRO

GC

HPLC

IBE

LD

LTA

MS

pol de $\mathrm{Hg}$

SAX

TLV-TWA

UV

VRT

$\lambda_{\max }$
- American Conference of Governmental Industrial Hygienists

- Ácido S-Fenilmercaptúrico (S-Fenil-N-Acetil-1-Cisteína)

- Ácido trans, trans-Mucônico

— Índice Biológico de Exposição

- Eletroforese Capilar

- Brometo de Cetiltrimetilamônio

- N,N-Dimetilformamida

- Detector de Ionização em Chama

- Fundação Jorge Duprat Figueiredo de Segurança e Medicina do Trabalho

- Cromatografia Gasosa

- Cromatografia Líquida de Alta Eficiência

— Indicador Biológico de Exposição

_Limite de Detecção

— Limite de Tolerância Ambiental

_ Espectrometria de Massas

_- Polegadas de Mercúrio

- Resina Fortemente Trocadora de Ânions

— Threshold Limit Value - Time Weight Average

- Ultravioleta e visível

_ Valor de Referência Tecnológico

- Comprimento de Onda de Máxima Absorção 


\section{RESUMO}

Os limites de exposição ocupacional ao benzeno, um agente carcinogênico, vêm diminuindo drasticamente nos últimos anos. Por outro lado, a concentração de benzeno em ambientes não ocupacionais tem aumentado devido à emissão biogênica e antropogênica, como exaustão de motores a gasolina e fumaça de cigarro. Indicadores Biológicos de Exposição (TBE) são utilizados como ferramentas importantes na avaliação da exposição humana ao benzeno. Com a diminuição dos limites de exposição, se faz necessário o desenvolvimento de metodologias analíticas com sensibilidade adequada para a determinação de IBE em fluidos biológicos que se correlacionem com baixas concentraçōes de benzeno absorvido pelo organismo.

A utilização do fenol urinário como IBE ao benzeno, embora reconhecida mundialmente, tem a desvantagem de não apresentar boa correlação com a concentração de benzeno ambiental quando esta é menor do que 10 ppm (32 $\left.\mathrm{mg} / \mathrm{m}^{3}\right)$. Os ácidos trans, trans-mucônico e S-fenilmercaptúrico, metabólitos do benzeno encontrados na urina, estão entre os compostos mais estudados como IBE ao benzeno.

Neste trabalho, o ácido trans,trans-mucônico foi determinado na urina de indivíduos expostos ao benzeno utilizando as técnicas de Eletroforese Capilar (CE) e HPLC, ambas com detecção no UV. Na determinação por HPLC foi adaptada uma metodologia da literatura utilizando coluna analítica com fase reversa. Na determinação por CE foi proposta uma metodologia empregando duas condições analíticas alternativas: uma que utiliza um capilar especial com cela ótica de alta sensibilidade e a outra que utiliza um capilar comum, mas com adição de um modificador orgânico ao eletrólito. As duas condições apresentaram grandes vantagens, como análise rápida (15 minutos) e baixo limite de detecção ( $25 \mu \mathrm{g} / \mathrm{L}$ ).

Foram analisadas amostras de urina de indivíduos fumantes e não fumantes onde a sensibilidade da metodologia proposta foi suficiente para diferenciar estatisticamente os dois grupos avaliados. 
The occupational exposure limits for benzene, a well-known carcinogenic agent, showed a drastic and continuous decrease in the last few years. In the other hand, benzene concentrations in non-occupational environments are increasing due to biogenic and anthropogenic emissions, like motor fuelled exhaustion and cigarette smoke. Biological markers of exposure are used like a powerful aid to evaluate human exposure for benzene. With the decrease of the exposure limits, the development of analytical methodologies is needed to accomplish adequate sensitivity for the exposure markers determination founded in biological fluids, in order to establish a correlation between the marker and the benzene concentration absorbed by organism.

One of the biological marker of exposure for benzene recognized worldwide is urinary phenol, but the exposure for benzene at concentrations smaller than 10 ppm (32 $\left.\mathrm{mg} / \mathrm{m}^{3}\right)$ usually is not correlated with urinary phenol concentration. The benzene metabolites trans,trans-Muconic and S-phenylmercapturic acids found in urine have been largely evaluated as biological markers of exposure.

At the present work, trans,trans-muconic acid in urine from exposed individuals was determined by Capillary Electrophoresis (CE) and HPLC using UV detection. For HPLC, a pre-established method from literature using reversed phase column was utilized. A new analytical method was proposed using $\mathrm{CE}$ in two different conditions: one utilized a special capillary with high sensitivity optical cell and the other utilized a common capillary and an organic modifier added to the electrolyte. Both conditions showed interesting advantages, such as short-time analysis (15 min) and lower limit of detection (L.O.D $=25 \mu \mathrm{g} / \mathrm{L}$ ).

Urine samples from smokers and non-smokers individuals were analyzed and the proposed method allowed statistical differentiation between these groups. 


\section{INTRODUÇÃO}

A tecnologia tem facilitado muito a vida do ser humano. Este é um fato contra o qual não há argumentos. $O$ mundo tem sofrido uma grande transformação nestes dois últimos séculos. Dia a dia as descobertas científicas mudam completamente as perspectivas de vida humana. No entanto, a mesma tecnologia que vem dar maior esperança de vida ao ser humano, também produz "resíduos" que lhe prejudicam a vida.

O equilíbrio deve sempre nortear qualquer ação de intervenção no ecossistema. Se, de um lado não se pode ir contra os avanços tecnológicos, por outro lado têm que ser criadas condições de vigilância sobre os prejuízos à saúde decorrentes destas mudanças.

Desta forma é importante o papel da vigilância sanitária detectando o maior número possível de agentes nocivos à saúde. É indispensável que as ferramentas usadas nesta vigilância sejam eficientes, ou seja, realmente detectem o que se propõem detectar quali e quantitativamente dentro das necessidades requisitadas.

A química analítica tem um papel de suma importância neste processo. É um trabalho analítico adequado que irá determinar o que é possível se avaliar (determinação qualitativa) e a que nível de concentração (determinação quantitativa).

\section{1 - BENZENO}

O benzeno é uma das substâncias químicas que causou grande impacto, principalmente na indústria química, desde a sua descoberta, em 1825 por Faraday, que o isolou de gás de iluminação. A importância do benzeno se deve às suas ótimas propriedades como solvente, altamente solúvel em solventes orgânicos graxos e escassamente solúvel em água. E um líquido incolor, altamente inflamável, com odor aromático característico, extremamente volátil à temperatura ambiente (Tabela I). 
TABELA I - Propriedades físicas do benzeno (a)

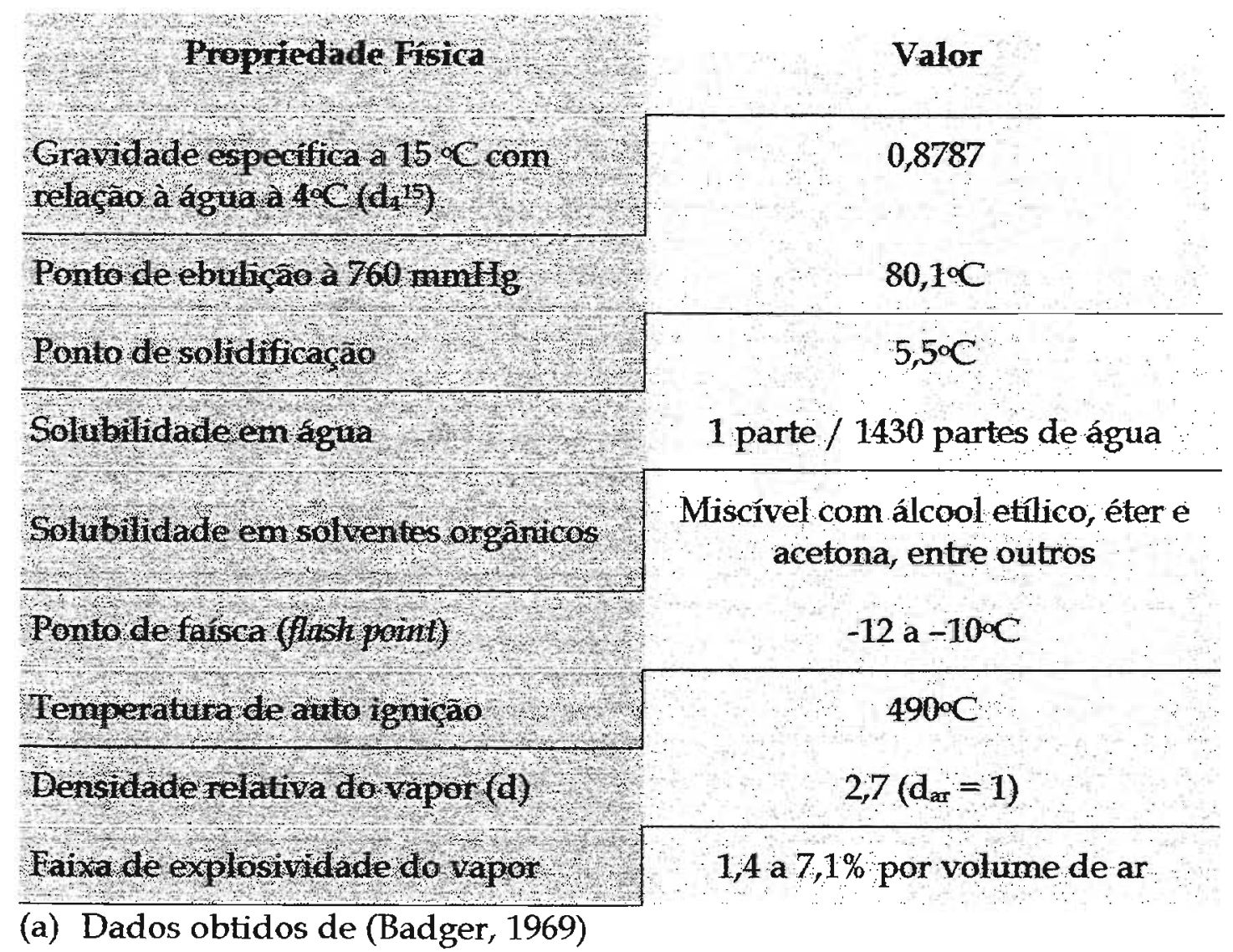

\section{1 - Histórico da exposição ocupacional ao benzeno}

O benzeno foi sintetizado pela primeira vez, em 1834 por Mitscherlich a partir do ácido benzóico; em 1845 foi isolado de carvão mineral (processo descoberto por Mansfield) e na segunda metade do século XIX começou a ser produzido em escala industrial e utilizado como matéria prima na produção de tecidos impermeabilizantes e de diversos produtos de borracha (Badger, 1969; Locatelli et al., 1995; Bartolucci et al., 1995). Com a utilização crescente do benzeno em escala industrial elevou-se a sua concentração ambiental e começaram as notícias dos primeiros casos de intoxicação em indivíduos expostos profissionalmente ao benzeno. Em 1897 houveram 4 casos fatais de benzolismo crônico descritos na literatura e, em 1916, ocorreram numerosos casos de pancitopenia e anemia aplástica em mulheres jovens que trabalhavam em uma indústria de pneus de bicicleta, na Suíça (Bartolucci et al., 1995). A elevada volatilidade fez do benzeno um excelente solvente para a borracha e a concentração ambiental alta levou à uma exposição 
ocupacional excessiva. Os trabalhadores ficavam expostos ao benzeno durante a dissolução da borracha, a borrifação sobre os tecidos ou o derramamento nas estampas e durante a secagem do produto.

A história da exposição ocupacional ao benzeno tem o seu período mais crítico entre os anos 20 e 30, quando este era largamente utilizado em vários processos industriais e a sua concentração atmosférica nos ambientes de trabalho não era controlada. Nos anos 30 se tornou o melhor solvente nas indústrias topográficas para a estampa à cores a alta velocidade. Um estudo chegou a apontar 32 trabalhadores expostos a uma concentração de benzeno no ambiente entre 150 ppm $\left(488 \mathrm{mg} / \mathrm{m}^{3}\right)$ e $650 \mathrm{ppm}\left(2113 \mathrm{mg} / \mathrm{m}^{3}\right)$ num período de 4 meses a 15 anos na Turquia (Bartolucci et al., 1995).

Nos anos 40 iniciaram os esforços para controlar a exposição ao benzeno no ambiente de trabalho. Nesta época verificou-se a necessidade de estabelecer limites para as concentrações nos ambientes de trabalho de substâncias que ofereciam perigo à saúde dos trabalhadores (xenobióticos). Desta forma estabeleceu-se o TLVTWA (Threshold Limit Value - Time Weight Average), que representa o valor máximo para a concentração média ponderada no tempo de um determinado xenobiótico sob a qual a maioria dos trabalhadores pode estar exposta sem prejuízo à sua saúde. $O$ TLV-TWA para o benzeno foi introduzido em 1941 com o valor de 100 ppm (325 $\mathrm{mg} / \mathrm{m}^{3}$ ). A OSHA (The Occupational Safety and Health Administration) e ACGIH (American Conference of Gozernmental Industrial Hygienists) estabeleceram o valor de 50 ppm (163 mg/m³) em 1947, 35 ppm (114 mg/m³) em 1948, 25 ppm (82 mg/m³) em 1957 e 10 ppm (33 mg/m³) em 1977 (Mastrangelo, 1996; Bartolucci et al., 1995).

Além do TLV-TWA, cujos valores são estabelecidos por órgãos oficiais de vários países, outros limites são estabelecidos para o controle da exposição ocupacional. Entre estes limites estão o TLV-STEL (TLV - Short Time Exposition Value) que é a concentração ambiental média de um determinado xenobiotico que um trabalhador pode estar exposto por um períod de 15 minutos, o TLV-Ceiling que é o pico de concentração de um determinado xenobiótico que um trabalhador pode estar exposto e o limite técnico (TRK - Technische Richtkonzentrationen), estabelecido na Alemanha para substâncias cancerígenas, o qual representa o valor mínimo de 
concentraçāo da substância cancerígena no ar controlável por uma determinada tecnologia, mas cuja observância não reduz o risco à saúde do trabalhador.

No mundo todo as políticas de saúde pública buscam baixar o limite de exposição ao benzeno a níveis de background, porém, para evitar a contração do câncer com segurança total uma pessoa deve estar exposta a nenhuma concentração do agente causador (Johnson $\mathcal{E}$ Lucier, 1992). Atualmente os limites de exposição propostos para o benzeno estāo entre $0,1 \mathrm{ppm}\left(0,33 \mathrm{mg} / \mathrm{m}^{3}\right)$ e $5,0 \mathrm{ppm}\left(16 \mathrm{mg} / \mathrm{m}^{3}\right)$. O menor limite é estabelecido pela NIOSH (National Institute for Occupational Safety and Health) e é igual a $0,1 \mathrm{ppm}\left(0,33 \mathrm{mg} / \mathrm{m}^{3}\right)$, enquanto que a OSHA estabelece 1,0 ppm $\left(3,3 \mathrm{mg} / \mathrm{m}^{3}\right)$, a ex-URSS $1,5 \mathrm{ppm}\left(4,9 \mathrm{mg} / \mathrm{m}^{3}=\mathrm{TLV}\right.$-Ceiling $)$, a Inglaterra, Dinamarca e França (Health and Safety Executive) $5,0 \mathrm{ppm}\left(16 \mathrm{mg} / \mathrm{m}^{3}\right)$ e a Alemanha estabelece valores de $1,0 \mathrm{ppm}\left(3,3 \mathrm{mg} / \mathrm{m}^{3}\right)$ e $2,5 \mathrm{ppm}\left(8,1 \mathrm{mg} / \mathrm{m}^{3}\right)$ para o TRK (Pezzagno, 1995).

Desde 1990 a ACGMH propunha um abaixamento no TLV-TWA do benzeno para 0,3 ppm (1 mg/m³) (Yardley-Jones et al., 1991), porém, uma redução somente ocorreu em 1997 quando o valor passou para 0,5 ppm $\left(1,7 \mathrm{mg} / \mathrm{m}^{3}\right)$, enquanto que o valor para o STEL e o Ceiling ficou em $2,5 \mathrm{ppm}\left(8,0 \mathrm{mg} / \mathrm{m}^{3}\right)(\mathrm{ACGIH}, 1998)$.

\section{2 - Toxicidade do benzeno}

O benzeno é uma substância química reconhecidamente carcinogênica (ACGIH, 1998). As considerações a respeito da sua carcinogenicidade são baseadas em observações a longo prazo. Os testes para mutagenicidade com o benzeno e seus metabólitos dão resultados negativos, embora seja conhecido a quase uma década que metabólitos do benzeno provocam modificações no DNA (ácidos deoxirribonucleicos), um pré-requisito para a carcinogenicidade (Pellack-Walker $\mathcal{E}$ Blumer, 1986; Goldstein, 1989).

A toxicidade do benzeno tem sido caracterizada em trabalhadores expostos e manifestada através de hematoxicidade ou, com exposições prolongadas à altas doses, através de danos irreversíveis à medula óssea (Snyder $\mathcal{E}$ Hedli, 1996). Os efeitos hematotóxicos incluem anemia, leucopenia e trombocitopenia; quando há uma diminuição em todos os tipos de células sanguíneas, chamado de pancitopenia, geralmente se associa uma aplasia (desenvolvimento incompleto ou imperfeito do 
órgão) irreversível na medula óssea, a qual em muitos casos é fatal. Os indivíduos que sobrevivem à aplasia apresentam uma medula displástica, cujo sintoma está associado à síndrome mielodisplástica (preleucemia), um estágio anterior da leucemia mielóide aguda (Snyder $\mathcal{E} \mathrm{Hedli}$, 1996). No entanto, não é objetivo deste trabalho detalhar todos os efeitos à saúde observados em pessoas expostas ao benzeno. Candura et al. (1995), de Carvalho et al. (1993), e Barale (1995), entre outros, discorrem sobre os efeitos do benzeno à saúde humana abordando aspectos médicos e históricos.

A toxicidade relacionada ao benzeno se deve à natureza de alguns metabólitos, sejam estes finais ou intermediários (Pellack-Walker \& Blumer, 1986; Goldstein, 1989; Reuterwall et al., 1991; Yardley-Jones et al., 1991; Türkel \& Egeli, 1994; Barale, 1995; Karacic et al., 1995; Locatelli et al., 1995; Mastrangelo, 1995; Linet et al., 1996; Parke, 1996; Smith, 1996; Forni, 1996; Tunca \& Egeli, 1996; Collins et al., 1997). Os metabólitos mais tóxicos do benzeno são: muconaldeído, catecol, hidroquinona, 1,2,4-benzenotriol e benzoquinona (Yardley-Jones et al., 1991; Daiker et al., 1996). Acredita-se que os efeitos hematotóxicos e leucemogênicos relacionados com a exposição ao benzeno estão associados ao muconaldeído, um metabólito do benzeno que é eliminado pelo organismo através da urina como ácido trans,transmucônico (Zhang et al., 1995; Witz et al., 1996; Bleasdale et al., 1996). Outros estudos demonstram que a carcinogenicidade do benzeno está relacionada com as propriedades genotóxicas dos metabólitos: benzoquinona, fenol, hidroquinona, catecol, 1,2,4- benzenotriol e benzeno epóxido (Candura et al., 1995).

Nilson et al. (1996) encontraram uma diferença significativa entre um grupo de trabalhadores expostos ao benzeno da gasolina à concentrações inferiores a 0,3 $\mathrm{mg} / \mathrm{m}^{3}$, e um grupo de controle, avaliando as seqüelas do ataque ao DNA, um efeito de genotoxicidade.

\section{3 - Benzeno no Brasil}

A produção mundial de benzeno é cerca de 15 milhões de toneladas anuais e os maiores produtores são Estados Unidos da América, Japão e a Europa Ocidental (Fiordi et al., 1995). Os Estados Unidos produziram em 1992, 4,5 milhões de toneladas de benzeno (Locatelli et al., 1995). Porém, a tendência mundial é substituir 
o benzeno por outras substâncias equivalentes, sempre que possível, nos processos industriais, o que significa que estes números a respeito do benzeno devem diminuir com o passar dos anos.

O Brasil produzia no começo desta década, cerca de 600 mil toneladas anuais de benzeno, 95\% de origem petroquímica (pólos petroquímicos de Camaçari, Triunfo, Capuava e Cubatão) e 5\% proveniente da destilação seca do carvão mineral em siderúrgicas (CSN, COSIPA, AÇOMINAS E USIMINAS). Em 1989 o país destinou $16 \%$ da sua produção para a exportação e do benzeno destinado ao mercado interno, $95 \%$ foi utilizado como matéria prima na produção de etilbenzeno, cumeno, caprolactama, alquilbenzeno linear e anidrido maleico, enquanto que a maior parte dos $5 \%$ restante foram utilizados para a produção de álcool anidro, utilizado adicionado à gasolina, como combustível. Não se tem dados a respeito do teor de benzeno encontrado como impureza na gasolina consumida no país ou como componente de misturas carburantes adicionadas à ela, porém é sabido que a gasolina exportada contem 0,8 a 1,0\%, em peso, de benzeno (De Carvalho et al., 1995). O benzeno presente nos gases de escapamento de veículos automotores é, seguramente, a maior fonte deste xenobiótico no ar ambiente dos grandes centros urbanos do Brasil e do mundo.

A história da exposição ocupacional ao benzeno no Brasil é semelhante ao que ocorreu em outros lugares do mundo com o agravante de que no Brasil "muitos casos de leucemia e aplasia medular não têm sua etiologia investigada e registrada por uma falta de cultura médica e política de saúde que façam correlacionar o benzeno como agente etiológico, sendo a causa básica omitida ou relacionada como 'idiopática'. Tem-se conhecimento de apenas nove casos registrados no país de óbito por benzenismo no período de 1983 a 1993" (De Carvalho et al., 1995).

\subsection{1 - As legislações relacionadas ao benzeno}

Com a constatação dos efeitos tóxicos do benzeno à saúde do trabalhador exposto, a legislação brasileira, desde a década de 30, vem estabelecendo leis com o intuito de controlar a exposição ocupacional a este agente. Pelo decreto $n^{\circ} 21.417-A$, de 17 de maio de 1932, as mulheres foram proibidas de trabalhar expostas ao benzeno. Em 1978, a portaria 3214 do Ministério do Trabalho, de 08/06/78, 
regulamenta a Lei 6514, de 22/12/77, a qual estabelece o limite de tolerância ambiental (LTA) para 145 substâncias, entre elas, o benzeno. $O$ valor do LTA (equivalente ao TLV-TWA) para o benzeno foi estabelecido em $8 \mathrm{ppm}\left(26 \mathrm{mg} / \mathrm{m}^{3}\right)$ para uma jornada de 48 horas semanais e $16 \mathrm{ppm}\left(52 \mathrm{mg} / \mathrm{m}^{3}\right)$ a concentração máxima permitida no ambiente de trabalho (De Carvalho et al., 1995).

Em 1982 o Ministério da Saúde e Trabalho, através da Portaria no 03, de $28 / 04 / 82$, proibiu a fabricação de qualquer produto que contenha mais que $1 \%$, em volume de benzeno em sua composição. Em 1983, pela Portaria no 12, de 06/06/83, o fenol urinário fica estabelecido como indicador biológico de exposição (IBE) ao benzeno, cuja concentração normal é $30 \mathrm{mg} / \mathrm{L}$ e o valor limite é $50 \mathrm{mg} / \mathrm{L}$. Em 1993, a Secretaria de Estado da Saúde de São Paulo, através da Norma Técnica referente ao Diagnóstico da Intoxicação e Controle da Exposição Ocupacional ao Benzeno, aprovada pela Resolução SS184, de 08/06/93, desvinculou o benzeno das substâncias com LTA controlado, ao reconhecer o benzeno como substância cancerígena, proibindo qualquer exposição a ele ou contato por qualquer via e não recomendou o uso do fenol urinário reconhecendo que este não é um bom indicador de exposição ao benzeno (De Carvalho et al., 1995).

Devido as lacunas existentes na legislação com relação à real proteção da saúde do trabalhador exposto ao benzeno, o Ministério do Trabalho, através da Secretaria de Segurança e Saúde no Trabalho, instituiu pela Portaria SSST n॰ 10, de 08/09/94, o Grupo de Trabalho Tripartite sobre o Benzeno com o objetivo de propor ao Ministério do Trabalho um novo instrumento legal para a prevenção da exposição ocupacional a este agente cancerígeno. Como fruto do trabalho deste Grupo, o Ministério do Trabalho através da Portaria no 14 de 20/12/95 cria o ANEXO 13-A para a Norma Regulamentadora $n^{\circ} 15$ da Portaria MTb no 3214 de 08/06/78 o qual, entre outros, proíbe a utilização do benzeno excetuando algumas indústrias e laboratórios e estabelece o VRT (Valor de Referência Tecnológico) para o benzeno. O VRT-MPT (VRT - Média Ponderada pelo Tempo) corresponde à concentração média de benzeno no ar ponderada pelo tempo para uma jornada de 8 horas de trabalho e é igual a 2,5 ppm $\left(8,1 \mathrm{mg} / \mathrm{m}^{3}\right)$ para empresas siderúrgicas e 1,0 $\mathrm{ppm}\left(3,3 \mathrm{mg} / \mathrm{m}^{3}\right)$ para outras empresas que têm permissão para utilizar o benzeno. 


\section{4 - Benzeno como poluente em ambiente não ocupacional}

É reconhecido que a exposição ocupacional ao benzeno na metade deste século tenha atingido níveis tão altos quanto $3000 \mathrm{mg} / \mathrm{m}^{3}$ e atualmente a concentração média de benzeno nestes ambientes são inferiores a $2 \mathrm{mg} / \mathrm{m}^{3}$ (Cocheo, 1995). Com a diminuição da concentração de benzeno nos ambientes de trabalho, começou uma preocupação maior com os níveis de concentração de benzeno em ambientes não ocupacionais.

O benzeno de origem biogênica e antropogênica (laboratórios, indústrias químicas, petroquímicas, siderúrgicas, fumaça de cigarro, emissão veicular, solventes, etc.) é lançado na atmosfera e permanece estabelecendo um teor residual. Desta maneira, as pessoas ficam expostas ao benzeno com mais ou menos intensidade, dependendo do local onde se encontram.

Wallace constata que através de um estudo em grande escala realizado pela EPA (U.S. Enoironmental Protection Agency) e através de outros estudos mais recentes, foi demonstrado que as maiores fontes de emissão do benzeno em ambientes não ocupacionais são: fumaça de cigarro e exaustão automotiva, principalmente em locais de tráfego intenso (Wallace, 1996). O benzeno que adentra a atmosfera proveniente da emissão veicular tem origem em parte da composição da gasolina, a qual com a abolição do chumbo tetraetila como carburante passou a ter mais aromáticos na sua composição com a mesma finalidade. Estudos têm demonstrado que parte do benzeno presente na emissão veicular é originado da combustão da gasolina no interior do motor e o percentual deste benzeno no gás de escapamento depende da porcentagem de hidrocarbonetos aromáticos na composição do combustivel (Avella et al., 1995).

A contribuição do cigarro na poluição ambiental é muito grande. A fumaça do cigarro, devido à combustão incompleta do material orgânico do tabaco, contem mais de 4700 diferentes compostos na forma gasosa ou particulada, entre eles a nicotina, hidrocarbonetos policíclicos aromáticos, formaldeído, estireno, cloreto de vinila, $\mathrm{NO}_{2}, \mathrm{SO}_{2}, \mathrm{CO}, \mathrm{NH}_{3}$, acroleína e, também, o benzeno, sendo que muitos destes compostos sāo carcinogênicos (Fiordi et al., 1995). A concentração média de benzeno presente na fumaça de cigarro depende do tipo de tabaco e varia entre 40 e $50 \mu \mathrm{g}$ por 
cigarro e uma pessoa fumando 20 cigarros por dia inala entre 700 e $800 \mu \mathrm{g}$ de benzeno. Ambientes com fumantes apresentam uma concentração média de benzeno 30 a 50\% superior em relação a ambientes sem fumantes (Apostoli \& Alessio, 1995).

Cerca de $99 \%$ do benzeno adentra o organismo humano através da via respiratória. Como a ventilação pulmonar depende da atividade física, uma pessoa praticando um exercício físico pode absorver 50 a $100 \%$ mais benzeno do que uma em repouso (Apostoli $\mathcal{E}$ Alessio, 1995). Esta constatação alerta para o problema de absorção de benzeno por parte de pessoas que praticam exercícios físicos tais como caminhada ritmada, corridas e atividades com bicicletas ao lado de ruas e avenidas com tráfego intenso.

Para avaliar a contribuição antropogênica na concentração ambiental de benzeno, estudos comparando dois ou mais ambientes com contribuição diferenciada, como por exemplo, grandes centros urbanos e zona rural ou ambientes com e sem fumaça de cigarros, têm sido realizados.

Scherer et al. (1995) avaliaram a exposição ao benzeno de moradores de subúrbios e centros urbanos, fumantes e não fumantes, sendo que os não fumantes foram divididos em dois grupos: residentes em lares com e sem fumantes. Foram avaliadas as concentraçōes de benzeno no ar ambiente, na zona de respiração e no ar exalado, e do ácido trans, trans-mucônico urinário. Os autores encontraram que mais de $15 \%$ da exposição ao benzeno de não fumantes, habitantes em lares com fumantes, foram provenientes da fumaça do cigarro.

Wester et al. (1986), avaliando o teor de benzeno no ar ambiente e na respiração de fumantes e não fumantes, em um grande centro urbano e em um local afastado, encontraram que a concentração de benzeno no ar exalado de não fumantes, em ambos os sítios, foi maior do que no ar ambiente, sugerindo a possibilidade da existência de outras fontes, além do ar ambiente, tais como: fumaça de cigarro, solventes (incluindo a gasolina), dieta (especialmente o número de ovos consumidos), entre outras. Em um outro estudo foi encontrado que a contaminação do ar ambiente por benzeno está diretamente relacionada com a densidade populacional (Gilli et al., 1996). 
Avaliações de exposição ao benzeno através do ácido trans,trans-mucônico urinário têm revelado índices em pessoas não expostas ocupacionalmente que correspondem à exposições à concentrações superiores a $3,3 \mathrm{mg} / \mathrm{m}^{3}$. Estes resultados podem indicar que há pessoas expostas a estes níveis de benzeno na população ou há variações genéticas no metabolismo do benzeno. A possibilidade da ocorrência de artefatos durante as avaliações, tais como erros relacionados às determinações da exposição e/ou do ácido mucônico urinário, ou existência de outras fontes de ácido mucônico além do benzeno, deve ser sempre considerada (Johnson $\mathcal{E}$ Lucier, 1992).

\section{2 - INDICADORES BIOLÓGICOS DE EXPOSIÇÃO}

Muitos problemas relacionados à saúde humana estão ligados aos poluentes atmosféricos, desta forma é importante saber com que grau as exposiçōes ambientais e ocupacionais à estes xenobióticos resultam em efeitos adversos à saúde humana. Neste sentido, os indicadores biológicos de exposição (IBE) exercem um papel muito importante estabelecendo ligações entre os marcadores de exposições $e$ os marcadores de estágios precoces de desenvolvimento de doenças (Henderson, 1995).

Marcadores biológicos ou biomarcadores de exposição ou IBE, são marcadores em um sistema biológico que indicam se houve ou não exposição à um determinado xenobiótico. Diferentemente, biomarcadores de efeito são eventos biológicos precoces ou efeitos que são relacionados temporariamente, especificamente e consistentemente com a exposição. Idealmente um IBE deve ser específico para a substância em questão. Além disto, os níveis de IBE devem correlacionar com a extensão da exposição (Medeiros et al., 1997).

Há muitas vantagens na utilização de IBE e a própria Organização Mundial da Saúde reconhece que os IBE's melhoraram os métodos de avaliação da exposição humana aos agentes nocivos do meio ambiente, pois:

- permitem uma estimativa da dose biologicamente efetiva resultante de exposições através de diferentes meio ambientes;

- fornecem uma avaliação de efeito mais sensível; 
- permitem um reconhecimento precoce de agressões à saúde que possuem longos períodos de latência, como o câncer;

- auxiliam na detecção de variações inter-individuais na resposta à exposição aos agentes nocivos do meio ambiente e na identificação de grupos populacionais de riscos especiais;

- podem ser úteis para o entendimento dos mecanismos pelos quais os agentes nocivos do meio ambiente exercem efeitos adversos à saúde, formando as bases de ações de controle e de estratégias preventivas.

Apesar das vantagens na utilização de IBE a utilização destes para propósitos epidemiológicos é um campo em estágio inicial de desenvolvimento, pois poucos estão validados e disponíveis (WHO, 1995).

Wahrendorf (1995) relaciona alguns problemas normalmente encontrados em estudos com a utilização de IBE e descreve alguns parâmetros importantes para o planejamento de estudos empregando IBE.

A validação de um IBE é um processo difícil, mas necessário para que os resultados da sua utilização sejam confiáveis. Esta validação depende da relação do IBE com a exposição e com as conseqüências advindas desta exposição. No entanto, esta relação é difícil de ser encontrada em estudos humanos devido ao longo período de latência entre as exposiçōes, o aparecimento do marcador e a doença. Entretanto, sem este estudo a avaliação de risco individual se torna comprometida (Larsen, 1995). Outro fator importante na validação de um IBE é a utilização de métodos analíticos com sensibilidade e especificidade adequada. A probabilidade de uma interpretação errada pode ser aumentada devido a problemas com medidas analíticas. Desta forma, a validação também deve ser feita em termos da precisão, exatidão, sensibilidade e especificidade das determinações analíticas do indicador (Schulte $\mathcal{E}$ Talaska, 1995).

A ACGIH, assim como outros órgãos internacionais, estabelece índices biológicos de exposição (BEI's) para a avaliação da exposição ocupacional total (incluindo derme, ingestão e não-ocupacional) aos agentes nocivos à saúde. $O$ índice de exposição biológica (BEI) é um valor de referência estabelecido para a concentração de um metabólito de uma determinada substância, da própria 
substància ou de uma mudança bioquímica característica e reversível induzida pela substância, cuja medida pode ser realizada no ar exalado, na urina, no sangue ou em outra espécie biológica coletada de um trabalhador exposto (ACGIH, 1998). Poucas substâncias cuja concentração é controlada nos ambientes de trabalho possuem BEI's estabelecidos.

\section{1 - Metabolismo do benzeno}

O benzeno, um composto lipossolúvel, é metabolizado principalmente no fígado a benzeno epóxido e a partir do qual se originam diversos compostos hidrossolúveis, que são eliminados pela urina. Muitos trabalhos na literatura citam rotas metabólicas para o benzeno (Hinson et al., 1985; Henderson et al., 1989; Salgado $\mathcal{E}$ Pezzagno, 1991; Angerer $\&$ Hörsch, 1992; Astier, 1993; Ong $\mathcal{E}$ Lee, 1994; Candura et al., 1995; Henderson, 1996; Snyder \& Hedli, 1996; Medeiros et al., 1997). Um esquema metabólico baseado nestas referências é apresentado na Figura 1. 


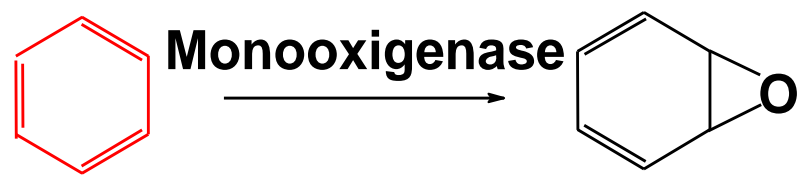

Benzeno

Benzeno Epóxido<smiles>OC1C=CC=CC1O</smiles>

trans-Di-Hidro-

Di-Hidroxibenzeno

$\mathrm{OHC}$

trans, trans-Muconaldeído

HOOC

Ácido trans, trans-Mucônico

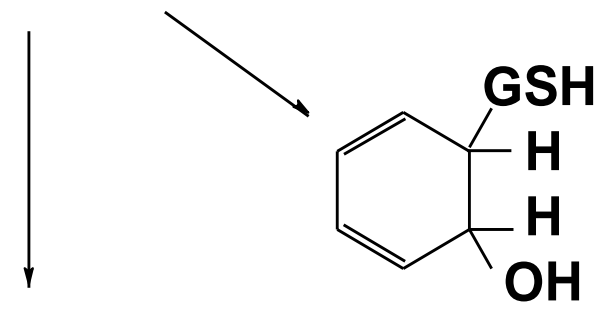

$\mathrm{OH}$

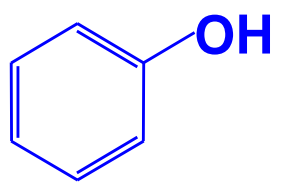

Aduto de Glutationa

Fenol $^{\#}$

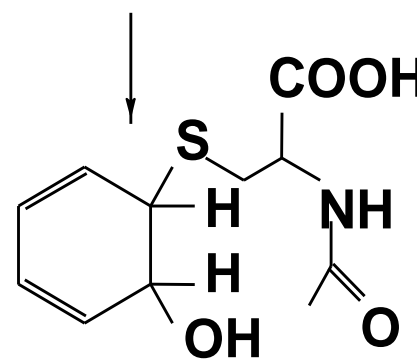

Ácido Fenil-Premercaptúrico

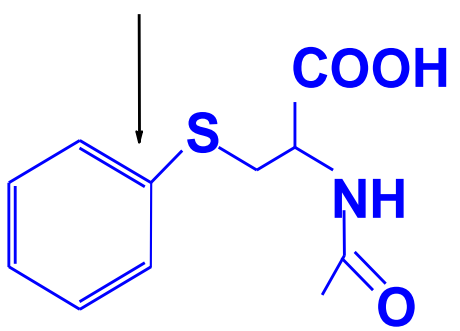

Ácido S-Fenilmercaptúrico

\# O fenol é o principal composto da rota fenólica da metabolização do benzeno. Os outros compostos são: catecol, hidroquinona, o- e p-benzoquinona, 1,2,4benzenotriol.

Figura 1 - Esquema metabólico do benzeno. 
Jaffé (1909), isolando o ácido mucônico da urina de cachorros e coelhos que haviam sido tratados com benzeno, foi o primeiro a relacionar este metabólito ao benzeno inalado. Parke e Williams (1952) com procedimentos semelhantes conseguiram identificar e quantificar o ácido mucônico em urina de coelhos, verificando que $99,95 \%$ deste ácido estava na forma trans, trans e apenas $0,05 \%$ ou menos na forma cis, cis ou cis,trans. Estudando o metabolismo do benzeno, Zhang et al. (1995) mostraram que o trans-di-hidro di-hidroxibenzeno (benzeno di-hidrodiol) é biotransformado primeiramente a cis,cis-muconaldeído, o qual é biotransformado a cis,trans-muconaldeído e, depois a trans,trans-muconaldeído para finalmente ser biotransformado ao ácido trans,trans-mucônico. Segundo os autores, o cis,cismuconaldeído e o cis, trans-muconaldeído são muito instáveis para serem oxidados aos respectivos ácidos mucônico e, somente o trans,trans-muconaldeído é convertido a ácido trans,trans-mucônico (AM). Este processo de biotransformação ocorre principalmente no fígado (Grotz et al., 1994).

Parke $\mathcal{E}$ Williams (1951), administrando benzeno em coelhos, demonstraram que cerca de $1 \%$ do benzeno foi biotransformado a ácido S-fenilmercaptúrico (Sfenil-N-acetil-1-cisteína) e eliminado pela urina. $O$ ácido S-fenilmercaptúrico (AFM) é metabolizado do benzeno através da glutationa. A glutationa é um tripeptídeo $(\gamma$ glutamil-cisteinilglicina) que pela ação da enzima glutationa S-epóxido-transferase se liga ao benzeno epóxido formando o 1-glutationil-2-OH-3,5-ciclo-hexadieno (Snyder \& Hedli, 1996). Este, por sua vez, pela transpeptidação perde o resíduo glutamil e, em seguida, por uma hidrólise perde a glicina. O composto resultante é acetilado pela acetil-coenzima-A a ácido S-fenil premercaptúrico o qual perde uma molécula de água formando o AFM que é eliminado pela urina.

\section{2 - Indicadores biológicos de exposição ao benzeno}

Vários metabólitos do benzeno têm sido estudados para a possibilidade de utilização como IBE. O principal metabólito do benzeno é o fenol, o qual é excretado principalmente pela urina, livre ou combinado com os ácidos glicurônico ou sulfúrico (Timbrell \& Mitchell, 1977; Tunek et al., 1978; Greenlee et al., 1981 e Hinson et al., 1985). 
A determinação de fenol na urina como IBE ao benzeno foi aceita mundialmente. Porém, devido ao fato de indivíduos não expostos ao benzeno apresentarem uma concentração de fenol na urina entre 19 e $81 \mu \mathrm{mol} / \mathrm{L}$ não é possivel distinguir, por este indicador, populações expostas à concentrações de benzeno inferiores a $10 \mathrm{ppm}\left(33 \mathrm{mg} / \mathrm{m}^{3}\right)$ daquelas não expostas. Por outro lado, muitas substâncias químicas, ingeridas em alimentos e remédios, também influenciam nos níveis de fenol urinário (Pekari, 1994).

Com a diminuição do LTA ao benzeno, outros IBE estão sendo sugeridos. Entre estes estão os ácidos trans, trans-mucônico e S-fenilmercaptúrico determinados na urina.

A ACGIH, desde 1997, adota a determinação do AFM urinário no final de um turno de trabalho e o valor de $25 \mu \mathrm{g} / \mathrm{g}$ de creatinina como BEI do benzeno e alerta para o fato de estar inserido neste valor quantidades significativas encontradas em indivíduos não expostos ocupacionalmente (ACGIH, 1998).

Inoue et al. (1989b) avaliaram a possibilidade de utilizar a determinação do 1,2,4-benzenotriol urinário como indicador biológico de exposição ao benzeno. Porém constataram que embora seja um indicador biológico específico, uma fração muito pequena é biotransformada, além do que, sua concentração urinária é reduzida drasticamente em uma co-exposição ao tolueno.

O benzeno determinado no sangue, no ar exalado e na urina, também pode ser utilizado como IBE pois, apesar de $30 \%$ de todo benzeno inalado ser imediatamente eliminado pela expiração e $50 \%$ biotransformado principalmente no fígado, parte do benzeno que penetra no organismo permanece inalterado nos tecidos gordurosos, no sangue e nos rins, sendo eliminado pelo pulmão (expiração) e na urina.

A determinação de benzeno no ar exalado apresenta a desvantagem do fato do ar exalado não ser uma amostra homogênea e sim uma mistura que depende não somente da exposição anterior, mas também do núvel de ventilação pulmonar de cada indivíduo e da atividade física antes da coleta (Salgado $\mathcal{E}$ Pezzagno, 1991). Apesar disso, a determinação de benzeno no ar exalado misturado (médio) e alveolar (final) realizada antes do início do turno de trabalho é uma determinação 
indicada pela ACGIH (1998). Existem trabalhos na literatura que descrevem a otimização desta determinação (Wester et al., 1986; Perbellini et al., 1988; Brugnone et al., 1989; Money \& Gray, 1989, Pekari et al., 1992 e Riedel et al., 1996).

O principal problema na determinação de benzeno no sangue reside no fato de ser uma matriz biológica pouco homogênea e a coleta da amostra ser um processo invasivo. Apesar destas desvantagens, muitos pesquisadores têm se dedicado à determinação da exposição ao benzeno por esta via (Perbellini et al., 1988; Brugnone et al., 1989; Hajimiragha et al., 1989; Angerer et al., 1991; Pekari et al., 1992; Kok \& Ong, 1994).

A dificuldade para a determinação de benzeno urinário como $\mathrm{IBE}$ é a baixa concentração deste na urina humana. Apenas 0,1 a $0,2 \%$ do benzeno inalado pelo homem é eliminado pela urina sob esta forma. Ghittori et al. (1993) propõem um método bastante sensível para a determinação de benzeno na urina para avaliar a exposição de pessoas ao benzeno a concentrações até $0,4 \mathrm{ppm}\left(1,3 \mathrm{mg} / \mathrm{m}^{3}\right)$. $\mathrm{O}$ benzeno é forçado a passar da fase líquida para a fase gasosa no sistema urina/ar pela adição de sulfato de sódio à urina, sendo então capturado em tubo de absorção com Carbotrap ${ }^{\odot}$. O benzeno deixa o tubo de Carbotrap ${ }^{\odot}$ com o auxílio de um equipamento de purge and trap e é analisado por cromatografia gasosa. Kok $\mathcal{E}$ Ong (1994) utilizaram a técnica de headspace acoplado a um cromatógrafo a gás para analisar o benzeno liberado da urina e o limite de detecção obtido foi igual a 40 $\mathrm{ng} / \mathrm{L}$.

É possível a monitorização da exposição ao benzeno através da determinação da N-7-fenilguanina na urina. O benzeno epóxido se liga ao DNA, RNA (ácidos ribonucleicos) ou proteínas, os quais como mecanismo de reparo, liberam bases ariladas, entre elas a N-7-fenilguanina que pode ser determinada na urina por HPLC-UV após extração com cromatografia de troca iônica e cartuchos Sep-Pak C18. A concentração deste metabólito do benzeno na urina é máxima após 2 a 3 dias da absorção. O problema relacionado com esta determinação é que, embora ela seja específica e esteja diretamente ligada à carcinogenicidade do benzeno, a sensibilidade do método analítico impede avaliações de exposição à concentrações 
inferiores a 5 ppm $\left(16 \mathrm{mg} / \mathrm{m}^{3}\right)$ de benzeno no ar (Norpoth et al., 1988; Norpoth et al., 1996).

\subsection{1 - Ácido trans, trans-mucônico urinário}

O AM é um dos metabólitos do benzeno que tem sido muito estudado com o propósito de ser utilizado como $\mathrm{IBE}$, apesar de não ser um metabólito específico do benzeno. Vários tipos de alimentos utilizam ácido sórbico como preservante, tais como, queijos, vinhos, entre outros. Uma parcela do ácido sórbico absorvido pelo organismo humano, 0,12 a 0,18\%, é excretada na urina como AM (Ducos et al., 1990; Ruppert et al., 1997), porém esta quantidade, segundo alguns autores, não é suficiente para interferir na avaliação da exposição ambiental ao benzeno, (Ducos et al., 1990), mas, segundo outros, é um fator de confusão na avaliação de exposição à baixos níveis de benzeno realizada por este indicador (Maestri et al., 1996; Ruppert et al., 1997).

Boogaard \& van Sittert (1995), a partir da determinação de AM urinário em 52 amostras de urina de 27 trabalhadores, encontraram que a vida média deste metabólito é de 5,1 horas. O monitoramento do ar na zona de respiração e os dados do monitoramento biológico em 14 destes trabalhadores, foram suficientes para a determinação da porcentagem da dose de AM urinário excretado, cujo valor encontrado foi de 3,9\%, ou seja, 3,9\% do benzeno absorvido pelo organismo é biotransformado a $\mathrm{AM}$, o qual é excretado pela urina.

Muitas metodologias para a determinação do AM urinário têm sido desenvolvidas e podem ser encontradas na literatura. As extrações, derivatizaçōes, técnicas analíticas e os modos de detecção utilizados para a determinação do AM em amostras de urina humana, assim como os limites de detecção estão resumidos na Tabela II. 


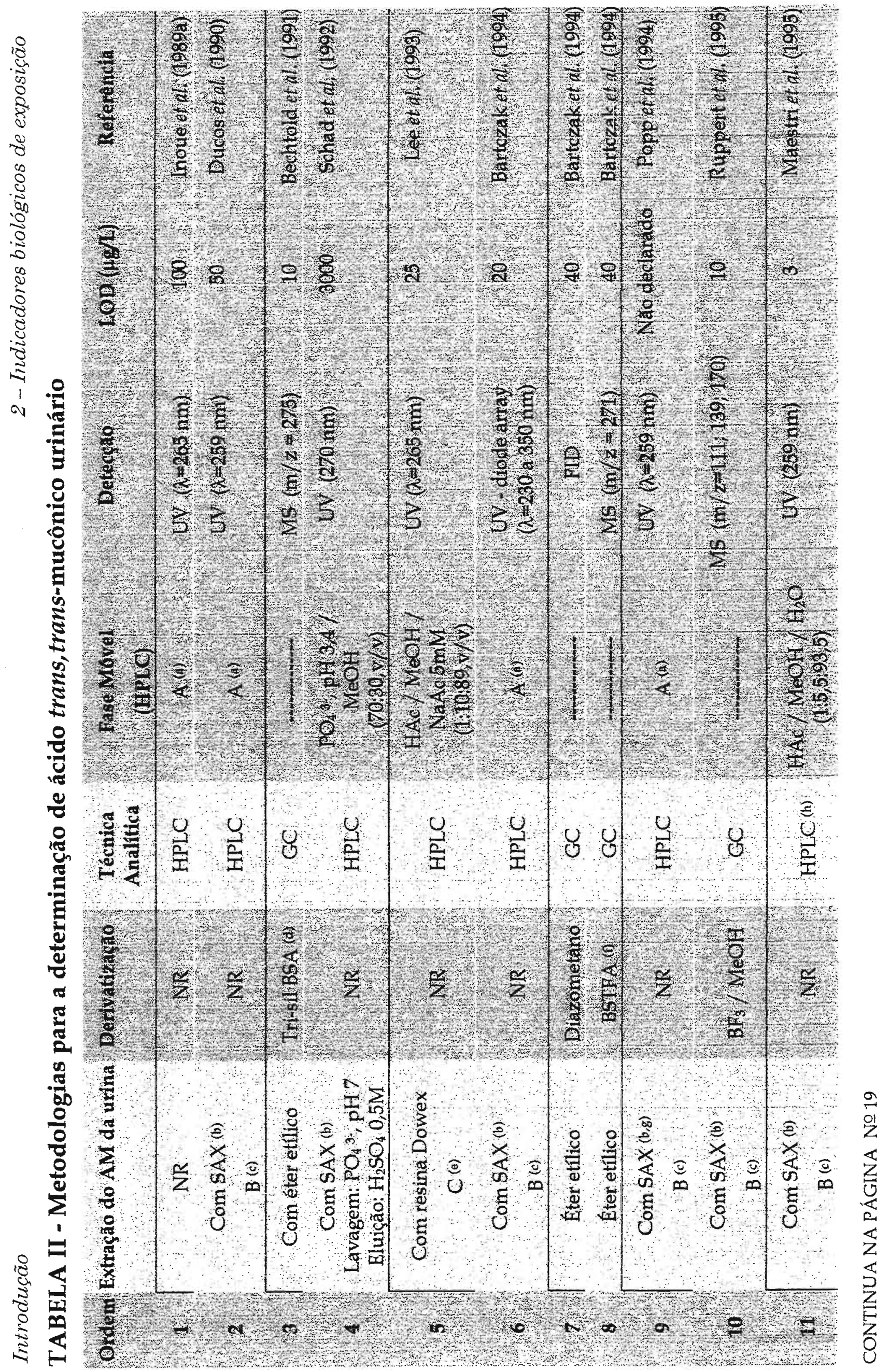




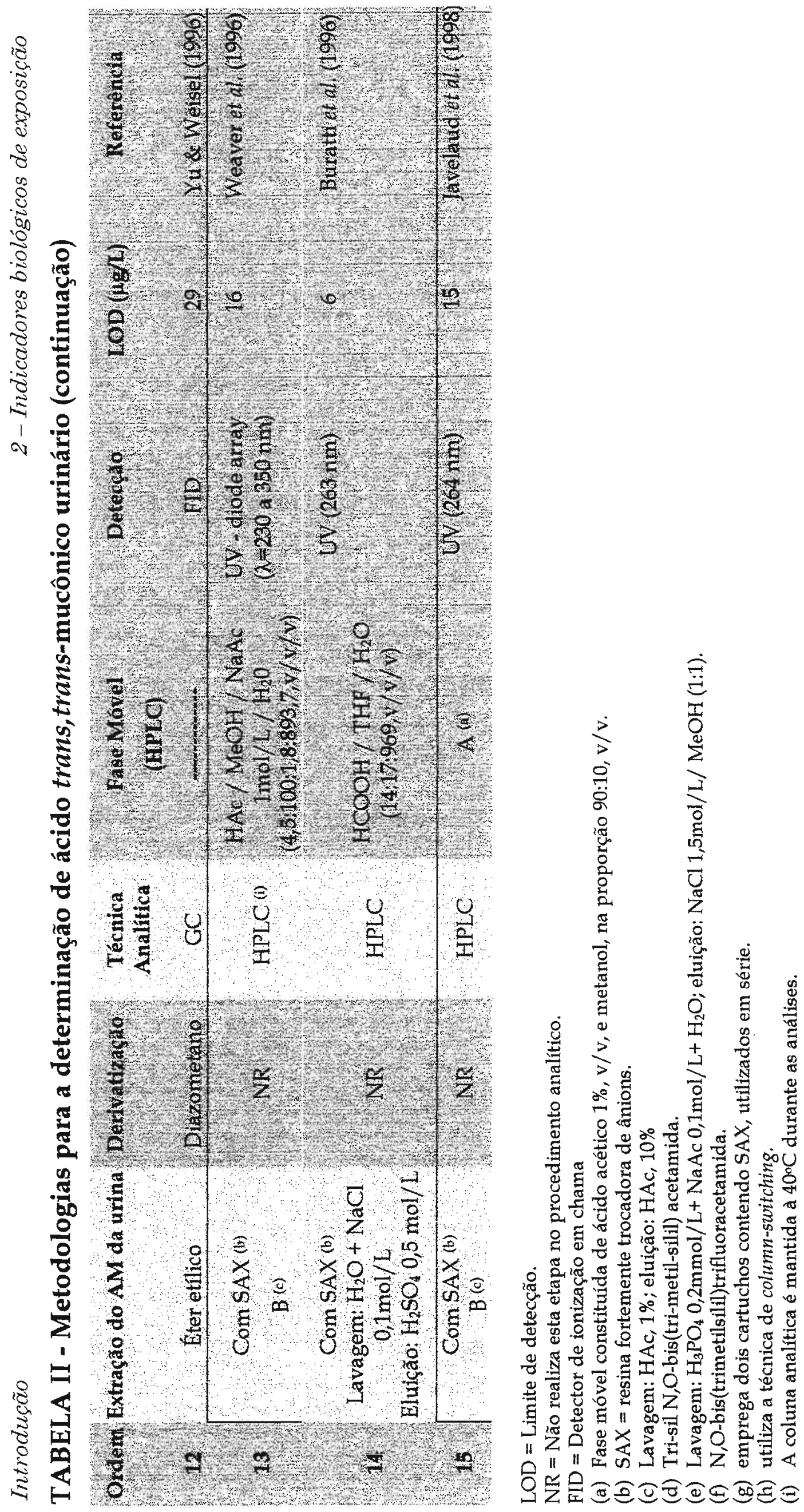


Todos os avanços conseguidos no campo analítico para a determinação de AM urinário aconteceram na década de 90 . O limite de detecção desta determinação diminuiu mais de 30 vezes desde o trabalho de Inoue et al. (1989a) até o de Maestri et al. (1995). A maioria dos limites de detecção das metodologias disponíveis encontram-se entre 10 e $40 \mu \mathrm{g} / \mathrm{L}$, o que permite distinguir entre uma população de não fumantes e não exposta ocupacionalmente ao benzeno, e uma constituída de fumantes não expostos.

Atualmente, a maior preocupação é avaliar as interferências que podem ocorrer na utilização do AM como IBE ao benzeno. Além do ácido sórbico, é sabido que a coexposição ao tolueno interfere na avaliação da exposição ao benzeno, subestimando os resultados (Inoue et al., 1989a; Brondeau et al., 1992; Zielinska-Psuja $\mathcal{E}$ Orlowski, 1995). Há suspeitas que hidrocarbonetos policíclicos aromáticos também interfiram nesta avaliação (Kivistö et al., 1997). Foi encontrado uma diferença estatisticamente significativa entre o AM urinário de motoristas de caminhão tanque com hábito de ingerir bebida alcoólica e os que não consumiam. $O$ consumo de álcool elevou a concentração média de AM urinário em mais de cinco vezes (Javelaud et al., 1998). O hábito de fumar é um outro fator de interferência na avaliação da exposição ocupacional ao benzeno. Na utilização do AM urinário como IBE ao benzeno deve ser considerado que a curva dose/resposta não é linear, no entanto, trata-se de um indicador biológico que responde à baixas concentrações de benzeno com grande sensibilidade (Witz et al., 1991).

Muitos estudos têm sido realizados com o objetivo de avaliar a correlação entre a concentração de benzeno ambiental e a de AM urinário em populações expostas ocupacionalmente (Inoue et al., 1989a; Bechtold et al., 1991; Ducos et al., 1992; Bechtold $\mathcal{E}$ Henderson, 1993; Lee et al., 1993; Popp et al., 1994; Boogard $\mathcal{E}$ Van Sittert, 1995; Ghittori et al., 1995a; Maestri et al., 1995; Ong et al., 1995; Boogard \& Van Sittert, 1996; Ong et al., 1996; Ghittori et al., 1996; Gobba et al., 1997; Kok et al., 1997; Kivistö, 1997; Javelaud et al., 1998). Estes foram baseados em um número grande de trabalhadores, nos quais a concentração de benzeno foi medida na zona de respiração. Em alguns trabalhos são apresentados resultados de estudos nos quais foram avaliados até cerca de 400 trabalhadores (Inoue et al., 1989a), enquanto que em outros, foram realizados até doze estudos diferentes com trabalhadores (Boogard $\mathcal{S}$ 
Van Sittert, 1995). Cada um destes estudos apresentou uma equação correlacionando a concentração de benzeno na zona de respiração com a concentração do AM urinário, a qual é apresentada juntamente com o respectivo coeficiente de correlação. Fatores, tais como, diferenças no sistema de amostragem (amostradores passivos e bombas de amostragem pessoal), diferenças possíveis nas metodologias, contato com o benzeno por outras vias que não a respiração, e outros, fazem com que os resultados, muitas vezes, sejam discrepantes.

Outros estudos têm procurado correlacionar a concentração de AM urinário com a exposição ao benzeno ambiental, mas não ocupacional. Têm sido comparadas populações de fumantes e não fumantes (Melikian et al., 1993; Ong et al., 1994; Lawerys et al., 1994; Ruppert et al., 1995; Buratti et al., 1996; Ghittori et al., 1996; Buratti et al., 1997; Ruppert et al., 1997; Coutrim et al., 1997a), habitantes do campo e da cidade (Ruppert et al., 1997), pessoas que ficam expostas ao benzeno do tráfego urbano (Weaver et al., 1996; Buratti et al., 1997), não fumantes expostos à fumaça do cigarro (Yu $\mathcal{E}$ Weisel, 1996).

\subsection{2 - Ácido S-fenilmercaptúrico urinário}

No início da década de 50, o AFM começou a ser pesquisado como metabólito do benzeno (Parke $\mathcal{E}$ Williams, 1951) e a partir do final desta década até o momento, têm sido propostas muitas metodologias para a utilização deste metabólito como IBE ao benzeno. Ele é um indicador biológico específico, ou seja, a única substância que é metabolizada a AFM pelo corpo humano, é o benzeno. Ele é eliminado pela urina e pode ser determinado nesta matriz.

Algumas metodologias para a determinação do AFM na urina descritas na literatura estão apresentadas na Tabela W. A maioria das metodologias propostas na década de 90 apresentam limites de detecção iguais ou inferiores a $1 \mu \mathrm{g} / \mathrm{L}$. Esta necessidade decorre do fato que o AFM é expelido pelo organismo humano em uma quantidade muito pequena. Van Sittert et al. (1993) observaram que apenas 0,11\% do benzeno que adentra o corpo humano é metabolizado à AFM com uma meia vida de eliminação igual a 9,6 horas, o que o torna apropriado para ser utilizado como $\mathrm{IBE}$, em especial no final de um turno de trabalho com jornada de 12 horas. Apesar destas vantagens, a execução difícil das metodologias analíticas existentes para a 
determinação deste metabólito do benzeno tem sido um dos grandes fatores de desencorajamento na utilização deste como IBE. Praticamente todas as metodologias usam extrair e derivatizar o AFM da urina antes da análise. As metodologias que não utilizam estas etapas (Jongennelen et al.,1987; Schäfer et al.,1993) apresentam limite de detecção inviável para a determinação deste metabólito como IBE ao benzeno. 


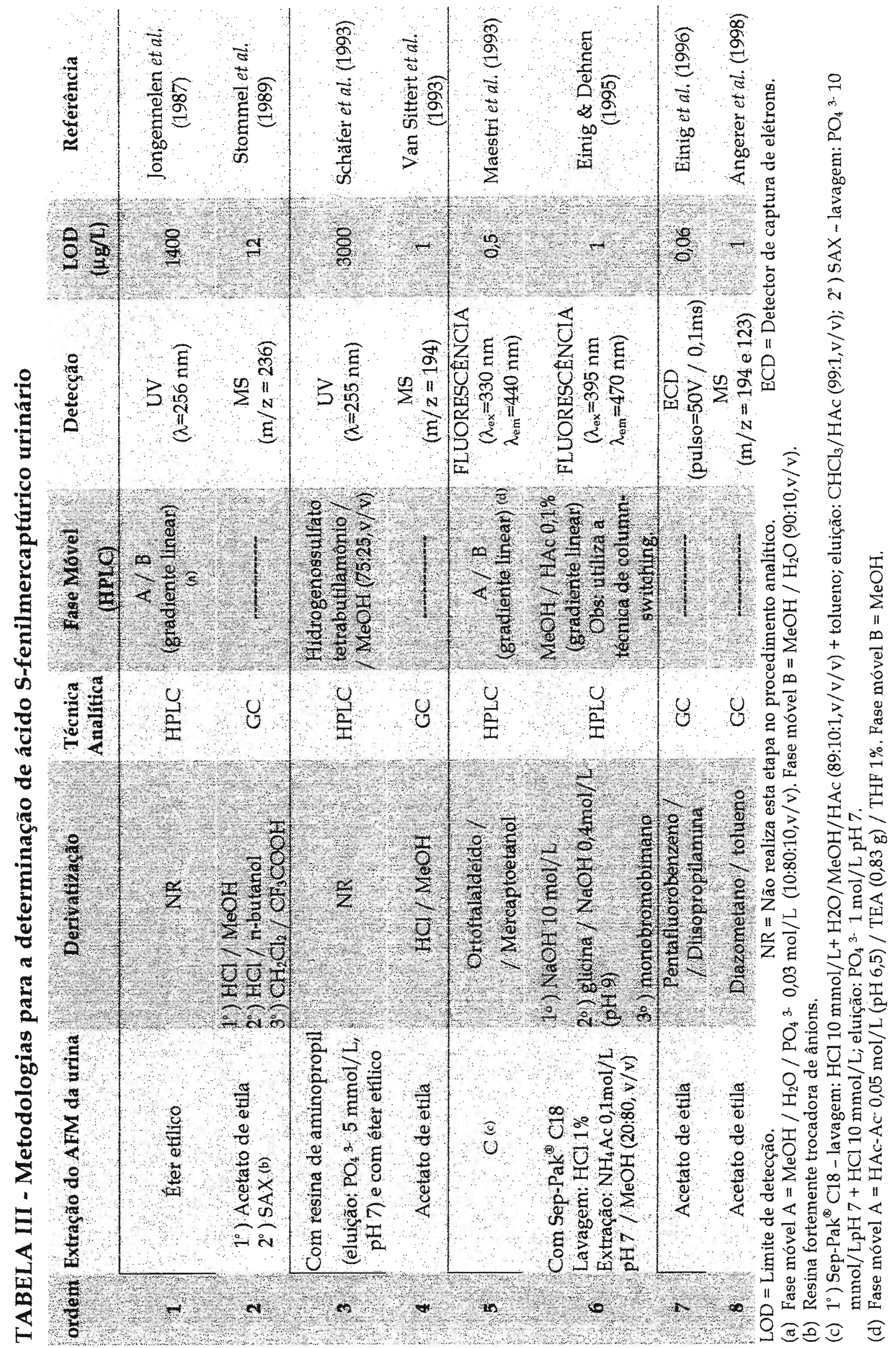


Vários trabalhos têm sido realizados com o objetivo de avaliar o AFM como IBE ao benzeno em ambientes ocupacionais (Jongennelen et al. 1987; Stommel et al., 1989; Maestri et al., 1993; Van Sittert et al., 1993; Popp et al., 1994; Boogaard \& Van Sittert , 1995; Ghittori et al., 1995a; Boogaard \& Van Sittert, 1996; Kivistö et al., 1997; Maestri et al., 1997; Angerer et al., 1998). Alguns destes trabalhos apresentam a equação que correlaciona a concentração de benzeno ambiental e AFM urinário com o respectivo coeficiente de correlação (Van Sittert et al., 1993; Boogard \& Van Sittert, 1995; Ghittori et al., 1995a; Boogaard \& Van Sittert, 1996; Kivistö et al., 1997; Maestri et al., 1997).

Estudos com avaliaçōes da concentração de AFM urinário de fumantes e não fumantes têm demonstrado que este IBE é suficientemente sensível para estabelecer diferenças estatísticas entre estas duas categorias (Maestri et al., 1993; Einig $\mathcal{E}$ Dehnen, 1995; Einig et al., 1996; Maestri et al., 1997). Semelhante ao encontrado nos estudos do AM urinário, estes estudos também mostraram que o hábito de fumar é um fator de confusão na avaliação da exposição ao benzeno através do AFM urinário. 


\section{JUSTIFICATIVA}

A FUNDACENTRO (Fundação Jorge Duprat Figueiredo de Segurança e Medicina do Trabalho), órgão do Ministério do Trabalho, teve a incumbência de apresentar um protocolo para a avaliação de grupos de riscos expostos ocupacionalmente ao benzeno, ditada pela Instrução Normativa $\mathrm{n}^{\circ} 2$ do Anexo $13 \mathrm{~A}$ da Portaria $\mathrm{n}^{\circ} 14$ da Secretaria de Segurança e Saúde no Trabalho ligada ao Ministério do Trabalho. Neste protocolo deve constar a apresentação de indicadores biológicos, com as respectivas metodologias analíticas, que avaliem exposiçōes ocupacionais à concentrações baixas de benzeno no ar, levando em conta as condições dos trabalhadores em estudo.

O Instituto de Química da Universidade de São Paulo, através do LEMA (Laboratório de Estudos do Meio Ambiente) foi uma das entidades de pesquisa convidada à auxiliar a FUNDACENTRO no desenvolvimento de metodologias analíticas para a determinação de indicadores biológicos de exposição ao benzeno. Assim, foi necessário propor e desenvolver um projeto de pesquisa sobre o desenvolvimento de metodologias para a determinação de AM e AFM urinários. 


\section{OBJETIVOS}

Com o objetivo geral de desenvolver metodologias analíticas para a determinação de indicadores biológicos adequados para o monitoramento da exposição humana ao benzeno, têm-se os seguintes objetivos específicos:

1. Avaliação de metodologias analíticas existentes para a determinação dos metabólitos do benzeno, AM e AFM, presentes na urina;

2. Desenvolvimento de metodologias analíticas para a determinação de AM e AFM, na urina, utilizando a técnica de eletroforese capilar, eliminando etapas de pré-tratamento da amostra;

3. Aplicação das metodologias desenvolvidas na análise de amostras de urina de indivíduos expostos ao benzeno através da fumaça do cigarro, fumantes e não fumantes. 


\section{ELETROFORESE CAPILAR}

Eletroforese é o movimento de partículas ou moléculas carregadas em um meio líquido condutivo, geralmente aquoso, sob a influência de um campo elétrico. Quando este processo ocorre dentro de um tubo de sílica fundida ou Teflon ou outro material adequado, com dimensões capilares, geralmente entre 25 e $75 \mu \mathrm{m}$, é dado o nome de eletroforese capilar (CE).

\section{1 - PRINCÍPIOS BÁSICOS DA TÉCNICA}

Eletroforese capilar é uma técnica que apesar de relativamente nova e tendo os equipamentos disponíveis comercialmente somente a partir da década de 80 , vem se mostrando poderosa e está rapidamente se popularizando. O número de usuários tem crescido vertiginosamente e tem sido utilizada nos mais variados campos de aplicação. Mais de 800 trabalhos foram avaliados em uma revisão bibliográfica abrangendo somente os anos de 1992 e 93 (Monning $\mathcal{E}$ Kennedy, 1994).

A construçâo de um equipamento de $\mathrm{CE}$ é relativamente simples. É constituído basicamente de um recipiente para a amostra, dois recipientes para o eletrólito, também chamado de tampão - um com o eletrólito de entrada e outro com o de saída, capilar, detector, fonte de alta voltagem, eletrodos conectados à esta fonte e colocados nos recipientes de eletrólito, registrador e integrador, os quais podem ser substituídos por computador. Um esquema do equipamento pode ser encontrado na Figura 2.

Para que o processo eletroforético ocorra, primeiramente, os recipientes que recebem o eletrólito são carregados. É importante que o eletrólito seja mantido em nível nos recipientes fonte e destino para que uma solução não seja transferida de um recipiente para o outro por sifonamento. O eletrólito é passado através do capilar e, após um tempo de condicionamento, a extremidade de entrada do capilar é colocada no recipiente contendo a amostra. Após a introdução da amostra no capilar, a extremidade de entrada deste é colocada novamente no recipiente fonte e um campo elétrico é aplicado entre os dois recipientes contendo o eletrólito. Os solutos contidos na amostra migram em tempos diferentes através do capilar e são 
detectados pelo detector colocado próximo à extremidade de saída do capilar. $\mathrm{O}$ sinal do detector é enviado para um integrador ou computador, onde é processado. O gráfico do sinal do detector contra o tempo é chamado de eletroferograma. $O$ eletroferograma é constituído de uma linha base, representando somente a passagem de eletrólito pelo detector e picos representando a passagem das substâncias presentes na amostra pelo detector.

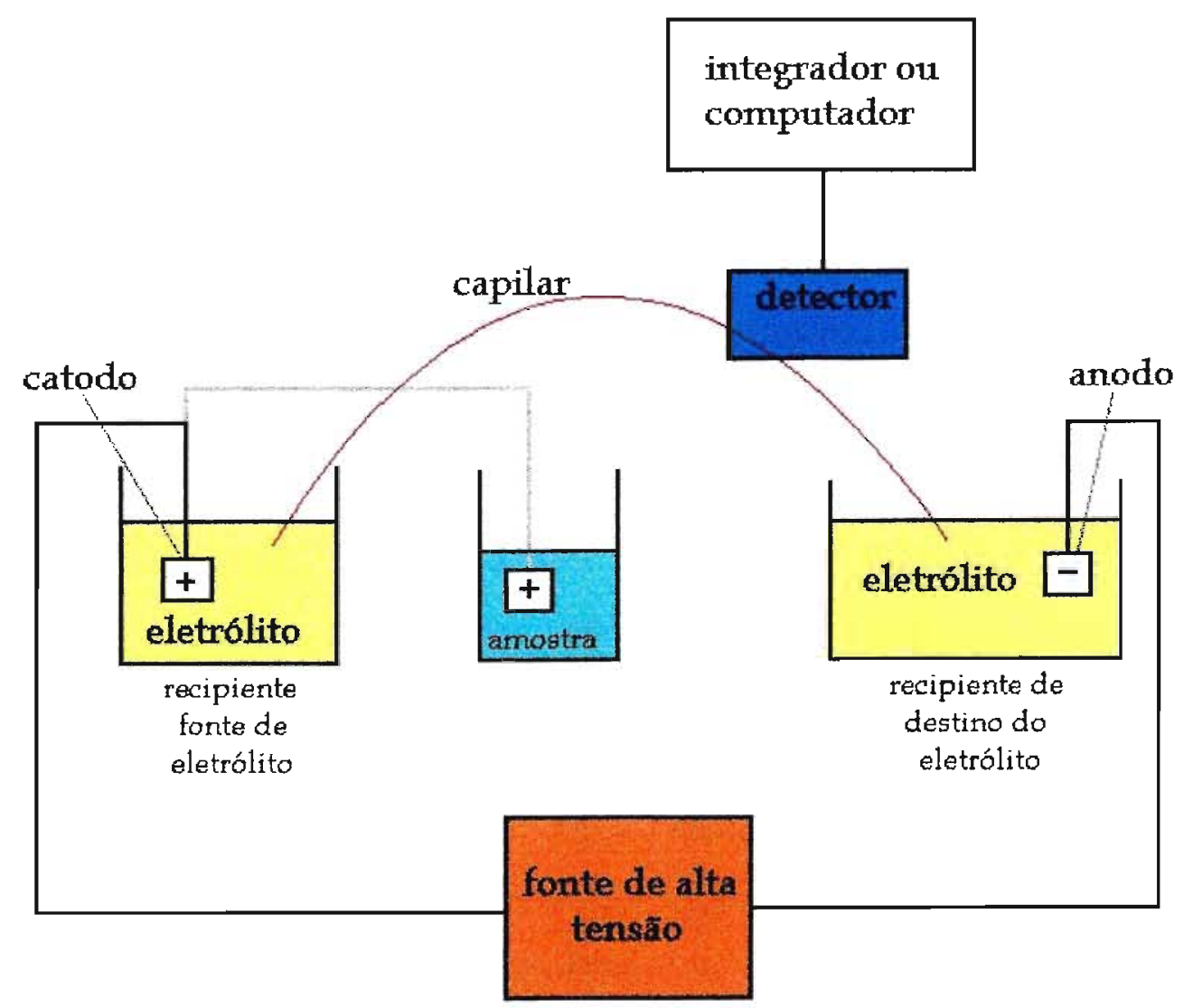

Figura 2 - Esquema representativo de um equipamento de eletroforese capilar. 
A composição do tampão é uma das variáveis mais importantes em CE. Pequenas mudanças no $\mathrm{pH}$ ou na concentração do tampão, significam alterações nas velocidades de migração do soluto $\mathrm{e}$, consequentemente, mudanças nos tempos de migração. Durante repetidas análises com o mesmo tampão, a composição deste é alterada devido à formação eletrolítica de íons hidrogênio no anodo e íons hidróxidos no catodo, além do que, o recipiente de destino do eletrólito tem sua composição alterada porque recebe todos os íons que passam pelo capilar. Por isso, o eletrólito contido nos recipientes de entrada e saída devem ser periodicamente renovados e nesta ocasião estes recipientes e o capilar devem ser lavados.

O capilar representa para a eletroforese capilar o que a coluna analítica representa para a cromatografia. É muito importante que ele esteja bem condicionado, que as seções transversais nos seus terminais estejam em um plano de $90^{\circ}$ em relação ao comprimento, que haja uniformidade no diâmetro interno e que a janela aberta para a detecção esteja muito limpa durante às análises quantitativas. Os capilares podem ser construídos em diversas dimensōes. Os mais comuns têm diâmetro externo igual a $375 \mu \mathrm{m}$, diâmetro interno de $50 \mu \mathrm{m}$ ou $75 \mu \mathrm{m}$ e comprimento entre 30 e $100 \mathrm{~cm}$, e são construídos de sílica fundida com revestimento de poliimida para conferir flexibilidade.

A cela de detecção utilizada em $\mathrm{CE}$ com detecção espectrofotométrica na faixa do visível e ultravioleta pode ser construída no próprio capilar utilizado para a separação. Há dois tipos de cela de deteç̧ão: aquela cujo caminho ótico é o diâmetro interno do capilar e é construída pela remoção de uma camada de aproximadamente $1 \mathrm{~cm}$ de poliimida, que envolve o capilar de sílica fundida; e aquela cujo caminho ótico é maior do que o diâmetro interno do capilar. Um caminho ótico maior pode ser obtido através da ampliação do diâmetro interno do capilar no ponto de detecção (cela de detecção em formato de bolha) ou situando o caminho ótico no leito do capilar, mas em um plano ortogonal ao comprimento do capilar. Para tal, dobra-se o capilar $90^{\circ}$ nas extremidades da cela de detecção aparecendo um formato em " $z$ " (capilar em " $z$ "). Alguns destes capilares tem cela de detecção com caminho ótico igual a $3 \mathrm{~mm}$ (Moring et al., 1993). 
A finalidade da fonte de alta tensão é fornecer um campo elétrico ao longo do capilar. A maioria delas são operadas à voltagem, corrente ou potência constante podendo reverter a polaridade. Normalmente são usadas voltagens de até $30 \mathrm{kV}$, correntes de até $300 \mu \mathrm{A}$ e potências de até $6 \mathrm{~W}$. O modo empregando voltagem constante é o mais largamente utilizado, pois uma alteração mínima na voltagem varia os tempos de migração.

Quando uma diferença de potencial é aplicada entre as extremidades de um capilar contendo uma solução iônica, a corrente produzida é responsável pelo surgimento de calor através do efeito Joule. Este aumento de temperatura no interior do capilar pode causar alterações na eficiência, tempo de migração, volume de injeção e resposta do detector, além de decompor a amostra ou mudar a configuração molecular dos solutos. Por exemplo, algumas proteínas são denaturadas à altas temperaturas. $O$ calor gerado pelo efeito Joule faz com que a temperatura no centro do capilar seja maior do que nas vizinhanças da parede, e isso possibilita que as moléculas de uma mesma espécie tenha uma velocidade maior na região central do capilar do que próximo às paredes. Em solução livre, há um aumento de cerca de $2 \%$ na mobilidade iônica devido a elevação de $1^{\circ} \mathrm{C}$ na temperatura. Algumas atitudes podem ser tomadas no sentido de dissipar este calor minimizando seus efeitos: $1^{\circ}$ ) adicionar um meio estabilizante ao tampão, como, por exemplo, um gel; $2^{\circ}$ ) manter o capilar em rotação durante a separação; $3^{\circ}$ ) reduzir o diâmetro interno do capilar; $4^{\circ}$ ) remover eficientemente o calor gerado, pela parte externa do capilar. $O$ uso de uma jaqueta com líquido refrigerante envolvendo o capilar, ou o uso de ventiladores e fornos no compartimento do capilar para manter a temperatura constante, permite remover o calor gerado.

Em CE a quantidade de amostra introduzida no capilar é da ordem de nanolitros, assim o recipiente para a amostra normalmente é muito pequeno com capacidade de alguns microlitros até poucos mililitros. Os tipos de introdução de amostra mais comuns em CE são: hidrodinâmica, podendo ser por pressão ou por gravidade, e eletrocinética. A injeção por gravidade é realizada com a elevação do recipiente de amostra com o capilar dentro, à uma certa altura e, assim, a amostra é sifonada para o capilar por gravidade. A injeção por pressão é realizada pela pressurização do recipiente da amostra levando-a para dentro do capilar ou 
apilicando vácuo na saída do capilar e puxando a amostra para dentro dele. A injeção eletrocinética é realizada pela aplicação de um campo elétrico entre o recipiente de amostra e o recipiente com eletrólito (destino), fazendo com que os componentes da amostra migrem para dentro do capilar.

A maioria dos equipamentos comerciais de eletroforese são providos de amostradores automáticos possibilitando que vários recipientes com amostra sejam carregados e as análises ocorram automaticamente.

As diferentes modalidades de eletroforese capilar são classificadas pelo mecanismo de separação ou pelo tipo de eletrólito empregado. Os tipos mais comuns são: de zona ou em solução livre (capillary zone electrophoresis - CZE), eletrocromatografia micelar (micellar electrokinetic capillary chromatography - MEKC), em gel (capillary gel electrophoresis - CGE), de focalização isoelétrica (capillary isoelectric focusing - CIEF) e isotacoforese capilar (capillary isotachophoresis - CITP). Nos tipos de CZE, MEKC e CGE, as separaç̃oes são realizadas em zonas, enquanto que a CIEF utiliza o modo de focalização isoelétrica e a CTTP o de fronteira móvel ou deslocamento (Baker, 1995).

A CZE é um tipo de eletroforese muito utilizado porque separa cátions e ânions na mesma corrida eletroforética. As espécies neutras não são separadas pela CZE. Para a separação destas espécies é utilizado a eletrocromatografia micelar.

Neste trabalho foi utilizado a CZE para a separação de ânions e, por isso, uma maior ênfase será dada a este tipo de eletroforese capilar, referindo a ele como CZE, ou apenas como CE.

Em CZE, as espécies presentes na amostra transferidas ao tubo capilar com o eletrólito, são separadas sob uma diferença de potencial. A separação ocorre porque estas espécies movem através do capilar em velocidades de migração diferentes, as quais são dependentes das mobilidades eletroforéticas. O fluxo eletroosmótico, que é o fluxo do eletrólito sob a voltagem aplicada, também influencia as velocidades de migração das espécies. O fluxo eletroosmótico leva o soluto através do capilar do anodo para o catodo. Um esquema deste tipo de separação é mostrado na Figura 3. Os cátions menores com mais carga chegam ao catodo antes que os maiores com menos carga, que por sua vez, chegam antes que as moléculas neutras, as quais não 
são separadas, mas chegam antes que os ânions. Alguns ânions pequenos muitas vezes não conseguem migrar, saindo do capilar pelo lado da injeção.

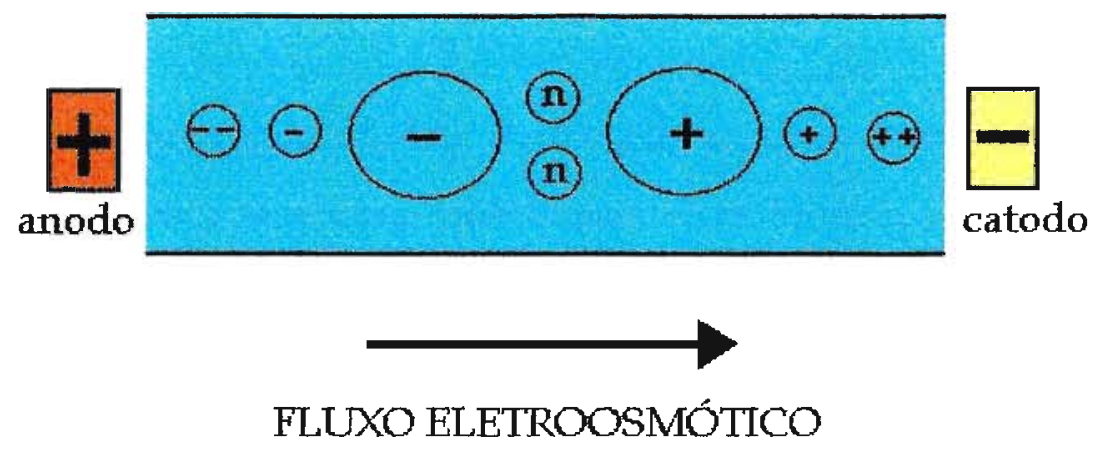

Figura 3 - Representação esquemática da migração de espécies aniônicas, catiônicas e neutras através do eletrólito dentro do capilar, devido ao fluxo eletroosmótico e mobilidades eletroforéticas (Baker, 1995).

A velocidade de uma espécie iônica (dada em $\mathrm{cm} / \mathrm{s}$ ) em uma separação eletroforética é determinada pela soma da velocidade eletroforética desta espécie e a velocidade do fluxo eletroosmótico relativo ao eletrólito.

A velocidade eletroforética é definida como a mobilidade eletroforética multiplicada pelo campo elétrico aplicado, em $\mathrm{V} / \mathrm{cm}$. A definição de mobilidade eletroforética $\left(\mu_{B B}\right)$ é dada por:

$$
\mu_{\mathrm{BF}}=q / 6 \pi \eta \mathbf{r}
$$

onde q é a carga da espécie iônica, $\eta$ é a viscosidade do eletrólito e $\mathbf{r}$ é o raio da espécie iônica. A unidade de mobilidade eletroforética é dada $\mathrm{em}^{\mathrm{cm}} / \mathrm{V}$.

Calculada da mesma maneira que a velocidade eletroforética, a velocidade do fluxo eletroosmótico é igual à mobilidade eletroosmótica multiplicada pelo campo elétrico aplicado, e a mobilidade eletroosmótica $\left(\mu_{\mathrm{EO}}\right)$ é definida por 


$$
\mu_{\mathrm{EO}}=\varepsilon \zeta / 4 \pi \eta
$$

onde $\varepsilon$ é a constante dielétrica do eletrólito, $\zeta$ é o potencial zeta e $\eta$ é a viscosidade do eletrólito.

Uma determinada espécie iônica movendo-se através do eletrólito em uma corrida eletroforética tem uma mobilidade eletroforética aparente $\left(\mu_{\mathrm{AP}}\right)$, a qual é a soma das mobilidades eletroforética $\left(\mu_{\mathrm{EF}}\right)$ e eletroosmótica $\left(\mu_{\mathrm{BO}}\right)$.

Em eletroforese "normal", onde o fluxo é dirigido para o catodo (Figura 3), as velocidades das espécies aniônicas são menores que a velocidade eletroosmótica, que por sua vez, é menor que as velocidades das espécies catiônicas. As espécies neutras movem-se com uma velocidade igual à velocidade eletroosmótica.

É possível inverter o fluxo eletroosmótico com adição de um surfactante catiônico ao eletrólito. A parte hidrofílica do surfactante se fixa à parede do capilar interagindo com os grupos silanóis. A parte hidrofóbica destas moléculas interage com a parte hidrofóbica das moléculas de surfactante que estão livres em solução. Os ânions do eletrólito, em solução, são atraídos pela hidrofilicidade destas últimas moléculas presas e, desta forma, são movidos em direção ao anodo. Este movimento dos ânions em solução, obriga o eletrólito mover em direção ao anodo, revertendo o fluxo eletroosmótico (Backer, 1995). Um esquema deste processo é mostrado na Figura 4. 


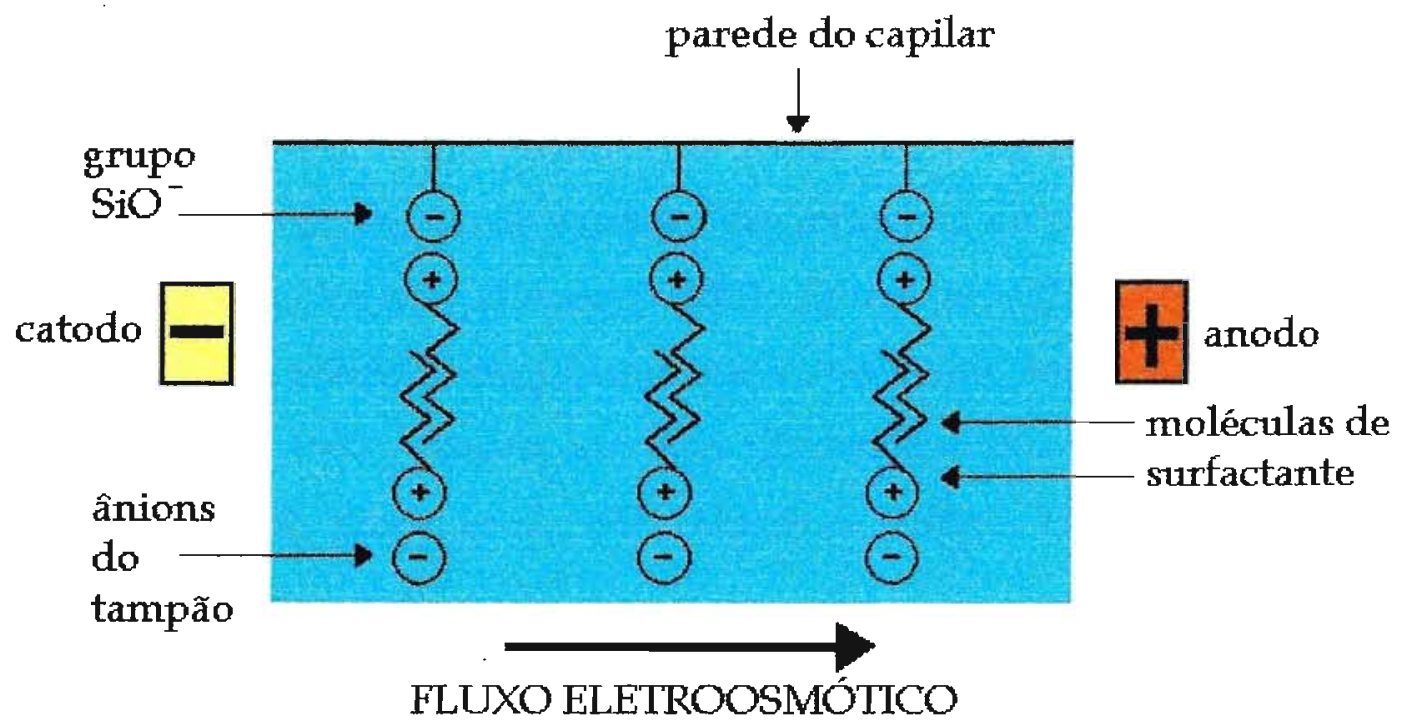

Figura 4 - Esquema do processo de reversão do fluxo eletroosmótico dentro do capilar devido à adição de um surfactante catiônico ao eletrólito.

Há uma concentração do surfactante no eletrólito, abaixo da qual o fluxo eletroosmótico não é invertido. Esta concentração é inferior a $10 \%$ da concentração micelar crítica $(\mathrm{CMC})$. Alguns surfactantes foram avaliados quanto à sua eficiência para a reversão do fluxo eletroosmótico e foi demonstrado que o brometo de cetiltrimetilamônio (CTAB) consegue essa reversão com menor concentração do que os outros surfactantes avaliados (Tavares et al., 1997).

Estão aqui apresentados os conceitos básicos, de forma resumida, sobre a separação de espécies iônicas em CZE. No entanto, abordagens mais detalhadas podem ser encontradas na literatura (Salomon et al., 1991; Heiger, 1992; Guzman, 1993; Marina \& Torre, 1994; Tavares, 1996).

\section{2 - DETERMINAÇÃO DE ÂNIONS DE BAIXA MASSA MOLAR EM MATRUZ BIOLÓGICA POR ELETROFORESE CAPILAR}

A análise de ácidos carboxílicos por $\mathrm{CE}$ tem sido avaliada por diversos autores. Os estudos envolvem desde a avaliação destes ácidos em soluções padrões 
A análise de ácidos carboxílicos por CE tem sido avaliada por diversos autores. Os estudos envolvem desde a avaliação destes ácidos em soluções padrões (Kenndler $\mathcal{E}$ Jenner, 1987; Kenndler $\mathcal{E}$ Jenner, 1989; Devêvre et al., 1994; Reid, 1994) como em matrizes, tais como: resíduos de indústrias de papel e celulose e tensos ativos utilizados em processos de extração em refinarias de petróleo (Romano et al., 1991); amostras de alimentos (Kenney, 1991); água e solo (Brumley $\mathcal{E}$ Brownrigg, 1993); e, mesmo em matrizes mais complexas como o soro humano (Schneede et al., 1994; Petucci et al., 1995); plasma humano (Zarzycki et al., 1995) e urina humana (Wildman et al., 1991; Shirao et al., 1994; Marsh \& Nuttall, 1995; Jellum et al., 1996; Coutrim et al., 1997a).

Análises de amostras de interesse biológico têm sido realizadas cada vez em maior número por CE, utilizando os diversos modos de separação. Xu (1995) apresenta uma revisão bibliográfica de 92 a 94 com mais de 160 referências enfocando apenas as análises de aplicação clínica realizadas por CE. Ainda, Baba (1996) apresenta uma revisão com mais de 100 referências, que abordam análises de substâncias relacionadas ao DNA.

Reid (1994) avaliou vários parâmetros eletroforéticos para otimizar a determinação de ânions orgânicos de interesse bioquímico, tais como os ácidos orgânicos hipúrico, benzóico, salicílico e outros, assim como a creatinina. As implicaçōes nas mobilidades eletroforéticas e eletroosmótica decorrentes do tempo de uso do capilar, concentração e força iônica do tampão e voltagem aplicada foram avaliadas. $\mathrm{O}$ autor, entretanto, avaliou apenas soluções padrões e é sabido que a complexidade da matriz da amostra interfere nos parâmetros eletroforéticos.

Utilizando a urina como matriz biológica, Wildman et al. (1991) avaliaram a separação de vários ácidos orgânicos e inorgânicos na urina, por $\mathrm{CE}$, no entanto, utilizaram a detecçāo por UV no modo indireto, onde é adicionada ao eletrólito uma substância que absorve fortemente em determinado comprimento de onda, no qual o analito absorve fracamente. Quando o analito está passando pelo detector o sinal aparece como uma depressão negativa na linha base e, com a inversão da polaridade do detector, esta depressão aparece como um pico positivo. A detecção indireta é adequada para a detecção de íons inorgânicos, mas é pouco sensível para os 
orgânicos. Jellum et al. (1996) apresentam a separação de mais de 50 metabólitos em amostras de urina por $\mathrm{CE}$, sem qualquer pré-tratamento da amostra e análise apenas qualitativa. Shirao et al. (1994) apresentam um método para a separação de vários ácidos orgânicos presentes na urina por CE utilizando o tampão borato de sódio e o tenso ativo CIA-Pak OFM Anion-BT, da Waters, na composição do eletrólito. A detecção foi feita por UV, pelo método direto, e os resultados quantitativos não foram apresentados; apenas foi apresentada uma comparação dos resultados de concentraçōes de alguns ácidos obtidos por CE e um analisador de ácidos.

Marsh e Nuttall (1995) apresentaram um método para a determinação de ácido metil-malônico na urina por $\mathrm{CE}$ com deteç̧ão por $\mathrm{UV}$, pelo modo indireto. $\mathrm{O}$ eletrólito foi constituído pelo ácido ftálico, tampão fosfato, CTAB e acetonitrila, como modificador orgânico. $\mathrm{O}$ analito foi extraído da urina com acetato de etila e o ácido succínico, um isômero, não interferiu nas análises. O limite de detecção encontrado pelos autores foi suficiente para detectar o analito pesquisado na urina de indivíduos saudáveis.

A influência da adição de metanol e dimetil-sulfóxido ao eletrólito, como modificadores orgânicos, foi avaliada nas mobilidades e constantes de dissociação de ácidos orgânicos separados por isotacoforese, em tubos capilares de politetrafluoroeteno com $300 \mu \mathrm{m}$ de diâmetro interno (Kenndler $\mathcal{E}$ Jenner, 1987; Kenndler \& Jenner, 1989). Schneede et al. (1994) avaliaram o comportamento de ácidos orgânicos de baixa massa molar separados por CE com adição de modificador orgânico ao eletrólito. Os autores avaliaram a adição de metanol e acetonitrila, individualmente e misturados, à varias concentraçōes, e suas implicações no fluxo eletroosmótico e mobilidades eletroforéticas das espécies analisadas; o modificador orgânico diminuiu o fluxo eletroosmótico tanto quanto a mobilidade eletroforética. Também foram avaliados os efeitos da temperatura e do comprimento do capilar nas referidas separações mostrando que o aumento da temperatura do capilar durante a separação provocou um aumento linear na corrente gerada e nas mobilidades eletroforética e eletroosmótica, enquanto que o aumento no comprimento do capilar implicou em aumentos lineares na resolução e no número de pratos. 


\section{PARTE EXPERIMENTAL}

\section{1 - EQUTPAMENTOS}

As avaliações para a determinação de AM em amostras de urina de indivíduos fumantes e não fumantes foram realizadas pelas técnicas de cromatografia líquida de alta eficiência (HPLC) e eletroforese capilar (CE). O AM foi extraído da urina antes de ser analisado por HPLC.

Alguns testes foram realizados visando a determinação de benzeno por cromatografia gasosa com detector de ionização em chama (GC-FID).

Foi avaliada a possibilidade de determinar o AFM, presente em amostras de urina humana por CE. Vários procedimentos para a extração do AFM da urina foram testados.

Os equipamentos utilizados neste trabalho são descritos a seguir:

\section{1 - Equipamento de cromatografia líquida de alta eficiência com detector} de UV-visível (HPLC-UV)

Para a realização dos experimentos envolvendo HPLC foi utilizado um equipamento da Shimadzu constituído das seguintes partes:

- sistema de degaseificação da fase móvel com gás hélio mod. DGU-2A;

- bomba de alta pressão com gradiente mod. LC-9A (2 unidades);

- injetor Rheodyne mod. 7161 com uma alça de amostragem de $10 \mu \mathrm{L}$;

- controlador de vazão de fase móvel mod. SCL-6B;

- detector espectrofotométrico de absorção no ultravioleta e visível (UVvis.) de comprimento de onda variável, mod. SPD-6AV, com faixa espectral igual a $8 \mathrm{~nm}$ e faixa de comprimento de onda de 195 a $700 \mathrm{~nm}$, utilizando lâmpadas de deutério e tungstênio;

- sistema de aquisição e processamento de dados mod. CR-4A com software da Shimadzu; 
- pré coluna Shim-pack CLC-GRD-ODS 4 (Shimadzu) 10 x 4,0 mm, diâmetro de partícula (dp) de $5 \mu \mathrm{m}$, fase estacionária octadecilsilano, ref. 228-18246-91, n० 3384;

- coluna analítica Spherisorb S3PC18 (Phase-Sep) $150 \times 4,6 \mathrm{~mm}, \mathrm{dp}=3,0 \mu \mathrm{m}$ (fase $=$ octadecilsilano), ref. S3PC18, n $^{\circ} 172219 ;$

- coluna analítica Shim-pack CLC-ODS (Shimadzu) $150 \times 4,6 \mathrm{~mm}$, dp = 5,0 $\mu \mathrm{m}$ (fase = octadecilsilano), ref. 228-17873-91, no 4154298;

- coluna analítica Ultrasphere ODS (Altex) $150 \times 4,6 \mathrm{~mm}, \mathrm{dp}=5,0 \mu \mathrm{m}$ (fase = octadecilsilano), ref. 256-06, n $1 \mathrm{UE} 1688 \mathrm{~N}$;

- coluna analítica Hibar RT 250-4 (Merck) 250 x 4,0 mm, dp =5,0 $\mu \mathrm{m}$ (fase $=$ octadecilsilano), ref. 1.50377.0001, no 742097 .

\section{2 - Equipamento de eletroforese capilar com detector de UV-visível (CE-} UV)

Para a realização dos experimentos envolvendo CE foi utilizado um equipamento da Applied Biosystem (Perkin-Elmer) mod. 270A-HT, equipado com:

- sistema de amostragem automático com capacidade para até 50 amostras e oito recipientes para fornecimento de eletrólito;

- um recipiente para a chegada do eletrólito;

- sistema de injeção tipo eletrocinético e/ou pneumático;

- termocontrolador;

- detector espectrofotométrico de absorção no ultravioleta e visível (UVvis.) de comprimento de onda variável, com faixa de comprimento de onda de 195 a $700 \mathrm{~nm}$, utilizando lâmpadas de deutério e tungstênio;

- software TURBOCHROM® para controle do equipamento através de uma interface, e para aquisição e tratamento de dados;

- capilar de sílica fundida com cela ótica de alta sensibilidade (capilar em “ $z$ ”), fabricado por LC Packings International, Amsterdã, Holanda, com as seguintes características: 
- caminho ótico $=3 \mathrm{~mm}$

- comprimento $=20 \mathrm{~cm}$ (seção curta) e $60 \mathrm{~cm}$ (seção longa)

- diâmetro $=75 \mu \mathrm{m}$ (interno) e $280 \mu \mathrm{m}$ (externo)

- capilares de sílica fundida (capilares comuns), fabricado por Polymicro Technologies, Phoenix, AZ, com:

- caminho ótico $=50 \mu \mathrm{m}$ ou $75 \mu \mathrm{m}$

- comprimento $=20 \mathrm{~cm}$ (seção curta) e $50 \mathrm{~cm}$ (seção longa)

- diâmetro $=50 \mu \mathrm{m}$ ou $75 \mu \mathrm{m}$ (interno) e $350 \mu \mathrm{m}$ (externo)

\section{3 - Equipamento de extração}

O AM e o AFM foram extraídos das amostras de urina através de um dispositivo de múltiplas extraçōes da Waters e cartuchos de extração da Varian com as seguintes características:

- Sep-Pak» Cartridge Rack, Waters Associates, Milford, Massachusetts, com possibilidade de receber até 8 cartuchos de extração. O solvente é eluído por vácuo de 5 a 10 polegadas de mercúrio obtido de uma bomba de vácuo da Sociedade Fabbe Ltda., tipo 2VC, mod. 161/1;

- Cartuchos Bond Elutब, Varian, Harbor City, CA, ref. 1210-2044, no 180420, com $500 \mathrm{mg}$ de trimetilaminopropilsilano, uma resina fortemente trocadora de ânions (SAX) e, capacidade para $3 \mathrm{~mL}$ de solvente. A resina SAX tem tamanho médio de poro igual a $76 \AA$, área superficial igual a 479 $\mathrm{m}^{2} / \mathrm{g}$, volume de poro igual a $0,91 \mathrm{~cm} / \mathrm{g}, \mathrm{pH}$ da superfície igual a $4,8 \mathrm{e}$ diâmetro de partícula igual a $56 \mu \mathrm{m}$;

- Cartuchos Sep-Pak® C18, Waters Associates, Milford, Massachusetts, ref. WAT051910, no T5266C1, contendo $360 \mathrm{mg}$ de dimetil-octadecilsilano e capacidade para $0,85 \mathrm{~mL}$ de solvente. A fase estacionária tem diâmetro de partícula igual a $80 \mu \mathrm{m}$; 
- Unidades filtrantes descartáveis, Millipore, Beldford, MA, ref. JBR 610021, $\mathrm{n}^{\circ}$ B7CM18807, com membrana Durapore $\mathrm{GV}^{\mathrm{de}} 0,22 \mu \mathrm{m}$ de poro, $25 \mathrm{~mm}$ de diâmetro e corpo em PVC.

1.4 - Equipamento de cromatografia gasosa com detector de ionização em chama (GC-FID)

Nos testes para a determinação de benzeno por cromatografia gasosa foi utilizado um equipamento da Shimadzu, modelo 14A, equipado com:

- detector de ionização em chama;

- utilizando como gás de arraste, hélio ultra puro e, como gás make-up, nitrogênio pưro;

- coluna capilar CBP - 1 (Shimadzu) $50 \mathrm{~m} \times 0,22 \mathrm{~mm}$ de diâmetro interno e $0,33 \mathrm{~mm}$ de diâmetro externo, espessura do filme $=0,25 \mu \mathrm{m}$, fase estacionária igual a metil silicona (metil polissiloxanano ligado à sílica), ref. 221-28635-50, $\mathrm{n}^{\circ} 77901$;

- coluna capilar CBP - 10 (Shimadzu) $50 \mathrm{~m}$ x 0,22 mm de diâmetro interno e $0,33 \mathrm{~mm}$ de diâmetro externo, espessura do filme $=0,25 \mu \mathrm{m}$, fase estacionária igual a fenil metil silicona (50\% de metil polissiloxano e $50 \%$ de fenilpolissiloxano ligados à sílica, com massa molar média igual a 4000 g/mol), ref. 221-28637-50, no 75481;

- coluna analítica CBP - 20 (Shimadzu) $50 \mathrm{~m} \times 0,22 \mathrm{~mm}$ de diâmetro interno e 0,33 $\mathrm{mm}$ de diâmetro externo, espessura do filme $=0,25 \mu \mathrm{m}$, fase estacionária igual a Carbowax $20 \mathrm{M}$ (polietilenoglicol com massa molar média de $20000 \mathrm{~g} / \mathrm{mol}$ ), ref. 221-28638-50, no 78517;

- sistema de aquisição e processamento de dados mod. CR-4A com software da Shimadzu.

\section{5 - Equipamento de ultra-som}

- equipamento de ultra-som com controlador de temperatura e frequência igual a $47 \mathrm{kHz}$, Cole-Parmer, modelo 8891-DTH, Chicago, Ilinois. 


\section{6 - Equipamento de espectrofotometria}

- equipamento de espectrofotometria UV-visível, Hitachi modelo U 3000, com faixa espectral de 190 a $1100 \mathrm{~nm}$;

- cela de quartzo com caminho ótico igual a $1 \mathrm{~cm}$.

\section{7 - Medidor de $\mathrm{pH}$}

- medidor de pH, Digimed modelo DM21, com termocompensador, modelo DMP1, e eletrodo combinado de vidro.

\section{8 - Balança Analítica}

- balança analítica, Mettler modelo AT 201, com capacidade para pesagens até 205 gramas e sensibilidade de $0,01 \mathrm{mg}$.

\section{2 - REAGENTES}

- Água deionizada obtida do equipamento Nanopure TM da Barnstead, Dubuque, IA, com filtro de $2 \mu \mathrm{m}$ de diâmetro de poro;

- Ácido trans,trans-mucônico (ácido trans,trans-hexa-2,4-dien-1,6-dióico), $\mathrm{C}_{6} \mathrm{H}_{6} \mathrm{O}_{4}$, ref. 70000, no 275982-191, pureza maior que 97\%, Fluka Chemika, Buchs, Suíça;

- Ácido S-fenilmercaptúrico (S-fenil-N-acetil-l-cisteína), $\mathrm{C}_{11} \mathrm{H}_{13} \mathrm{O}_{3} \mathrm{NS}$, ref. 133030010, no A010304301, pureza maior que 98\%, Acros (Fisher), Geel, Bélgica.

- Acetato de etila grau cromatográfico, Merck S/A Indústrias Químicas, ref. $868, \mathrm{n}^{\circ}$ 306020, Rio de Janeiro-RJ;

- Acetonitrila, grau cromatográfico, Merck Darmstadt, Alemanha, ref. 1142912500, n I556991;

- N,N-Dimetilformamida (DMF), pureza maior que 99,5\%, Merck S/A Indústrias Químicas, Rio de Janeiro-RJ, ref. 3034, no 502118.

- Éter dietílico grau cromatográfico, Merck S/A Indústrias Químicas, Rio de Janeiro-RJ; 
- Mietanol, grau cromatográfico (LiChrosolv ) $^{2}$ Merck, Gibbstown, NJ, ref. 1060182504, nº 34333;

- Acetato de amônio grau PA, Merck S/A Indústrias Químicas, ref. 21632, $n^{\circ}$ 504167, Rio de Janeiro-RJ;

- Acetato de sódio grau PA, Merck S/A Indústrias Químicas, Rio de Janeiro-RJ;

- Brometo de cetiltrimetilamônio (CTAB), pureza igual a 99\%, Aldrich, Milwaukee, WI;

- Fosfato monossódico monoidratado $\left(\mathrm{NaH}_{2} \mathrm{PO}_{4} \cdot \mathrm{H}_{2} \mathrm{O}\right)$, grau PA, Merck S/A Indústrias Químicas, Rio de Janeiro-RI, ref. 6346, n॰ 802009;

- Tetraborato de sódio grau PA, $\mathrm{Na}_{2} \mathrm{~B}_{4} \mathrm{O}_{7} .10 \mathrm{H}_{2} \mathrm{O}$, Synth (Labsynth Produtos para Laboratórios Ltda.), ref. 56650, no 6828, Diadema-SP;

- Ácido acético glacial, grau cromatográfico, J. T. Backer, Phillipburg, NJ, ref. 9515-03;

- Ácido acético glacial, grau PA, Merck S/A Indústrias Químicas, ref. 21606, $\mathrm{n}^{\circ}$ 1216066004, Rio de Janeiro-RJ;

- Ácido clorídrico fumegante, grau PA, Merck S/A Indústrias Químicas, ref. 21603, no 1216036018, Rio de Janeiro-RJ;

- Hidróxido de sódio em pastilhas, grau PA, Merck, Darmstadt, Alemanha, ref. 1064981000, no B164898-746;

\section{3 - SOLUÇÕES UTHLIZADAS}

- Ácido clorídrico $1 \mathrm{~mol} / \mathrm{L}$

- Ácido acético $10 \%, v / v$, (preparada no dia do uso, não estocada)

- Ácido acético 1\%,v/v, (preparada no dia do uso, não estocada)

- Hidróxido de sódio $10 \%, \mathrm{p} / \mathrm{v}$

- Hidróxido de sódio $1 \mathrm{~mol} / \mathrm{L}$ 
- Acetato de amônio 0,1 mol/L

- Tampão tetraborato de sódio $120 \mathrm{mmol} / \mathrm{L}$ (solução estoque)

3.1 - Preparação das soluções

\subsection{1 - Ácido trans,trans-mucônico (AM) 10 mg/L (solução padrão)}

Uma quantidade em torno de $1 \mathrm{mg}$ de $\mathrm{AM}$, pesada com precisão de $0,02 \mathrm{mg}$, foi transferida para um balão volumétrico de $100 \mathrm{~mL}$ com cerca de $10 \mathrm{~mL}$ de metanol. Após dissolução completa do sólido, o volume foi completado com água deionizada. Esta solução foi armazenada em frasco de polietileno à temperatura de $-20^{\circ} \mathrm{C}$ até a análise. As soluções padrões de concentrações inferiores foram preparadas a partir desta solução.

\subsection{2 - Ácido S-fenilmercaptúrico (AFM) $100 \mathrm{mg} / \mathrm{L}$ (solução padrão)}

Uma quantidade em torno de $10 \mathrm{mg}$ de AFM, pesada com precisão de 0,02 $\mathrm{mg}$, foi transferida para um balão volumétrico de $100 \mathrm{~mL}$ com cerca de $10 \mathrm{~mL}$ de metanol. Após dissolução completa do sólido, o volume foi completado com água deionizada. Esta solução foi armazenada em frasco de polietileno à temperatura de $-20^{\circ} \mathrm{C}$ até a análise. As soluções padrōes de concentrações inferiores foram preparadas a partir desta solução.

\subsection{3 - Brometo de cetiltrimetilamônio (CTAB) $4 \mathrm{mmol} / \mathrm{L}$ (solução estoque)}

Uma quantidade em torno de $145,8 \mathrm{mg}$ de CTAB, pesada com precisão de $0,02 \mathrm{mg}$, foi transferida para um balão de $100 \mathrm{~mL}$ com cerca de $50 \mathrm{~mL}$ de água deionizada. A solução resultante foi mantida em banho de ultra-som durante 2 minutos para a completa dissolução do sólido e o volume foi completado com água deionizada. Antes do uso, o frasco com a solução foi mantido no equipamento de ultra-som na posição de degaseificação durante dois minutos. A solução foi mantida em frasco de vidro transparente e após quinze dias foi descartada.

\subsection{4 - Fosfato de sódio $300 \mathrm{mmol} / \mathrm{L}$, tampão pH 7,0 (solução estoque)}

Uma quantidade em torno de 4,14 $\mathrm{g}$ de fosfato monossódico monoidratado, pesada com precisão de $0,02 \mathrm{mg}$, foi dissolvida com cerca de $60 \mathrm{~mL}$ de água deionizada em um béquer e a solução foi mantida em banho de ultra-som até a completa dissolução 
do sólido. Foram dissolvidas duas pastilhas de hidróxido de sódio na solução e, em seguida, adicionada solução de hidróxido de sódio 10\%, p/v, até pH 7,0 (cerca de 6 $\mathrm{mL}$ ). A solução resultante foi transferida para um balão volumétrico de $100 \mathrm{~mL}$ e o volume foi ajustado com água deionizada. Esta solução foi estocada em frasco de polietileno e descartada após quinze dias. Solução tampão de fosfato de sódio com $\mathrm{pH}$ diferente, foi preparada a partir desta com acerto do $\mathrm{pH}$ com hidróxido de sódio ou ácido clorídrico, conforme o caso. Antes do uso, o frasco com a solução foi mantido no equipamento de ultra-som na posição de degaseificação durante dois minutos.

\section{4 - AVAliAÇÃo DA DETERMINAÇÃO DE BENZENO POR HPLC-UV E POR GC-FID}

Foram preparadas soluções de benzeno em metanol a partir de diluição da solução mais concentrada na faixa de $440 \mathrm{mg} / \mathrm{L}$ a $44 \mathrm{ng} / \mathrm{L}$.

A análise destas soluçōes por HPLC foi feita na seguinte condição cromatográfica:

- coluna analítica: Shim-pack CLC-ODS;

- volume de injeção: $10 \mu \mathrm{L}$;

- fase móvel: metanol/água na proporção de 70:30, v/v;

- vazão da fase móvel: $1 \mathrm{~mL} / \mathrm{min}$;

- deteç̧ão UV: $210 \mathrm{~nm}$.

Também foram preparadas soluções de benzeno em etanol e acetona na mesma faixa de concentração descrita anteriormente. As análises das soluções de benzeno em metanol, etanol e acetona foram realizadas por GC-FID utilizando as colunas cromatográficas CBP-1, CBP-10 e CBP-20 e os seguintes parâmetros cromatográficos:

- volume de injeção: $1,0 \mu \mathrm{L}$;

- temperatura do injetor: $210^{\circ} \mathrm{C}$;

- temperatura do detector: $280^{\circ} \mathrm{C}$; 
- temperatura da coluna: $45^{\circ} \mathrm{C}$ por 10 minutos, até $250^{\circ} \mathrm{C}$ com rampa de aquecimento de $30^{\circ} \mathrm{C} /$ min e mantida a $250^{\circ} \mathrm{C}$ por 1 minuto;

- velocidade linear do gás de arraste: $16 \mathrm{~cm} / \mathrm{s}$;

- razão de split : 25:1;

- tempo de splitless : 30 segundos.

\section{5 - COT.FTA F ARMAZFNAMFNTO DF URINA}

Cerca de $150 \mathrm{~mL}$ de amostra de urina foram coletados em frascos de polietileno com batoque e tampa previamente lavados.

Logo após a coleta, cerca de $10 \mathrm{~mL}$ da amostra foram filtrados através de unidades filtrantes descartáveis e analisados em seguida. Cinco frações de 1,5 mL de cada amostra foram armazenadas em recipientes plásticos a $-20^{\circ} \mathrm{C}$. $\mathrm{O}$ restante das amostras de urina foi mantido à $-20^{\circ} \mathrm{C}$ nos próprios recipientes de coleta. As amostras foram descongeladas naturalmente à temperatura ambiente e filtradas em unidades filtrantes descartáveis antes de cada análise.

As amostras de urina utilizadas neste trabalho foram coletadas em duas etapas, a primeira com 20 amostras e a segunda com 32 . O teor de creatinina foi determinado somente nas amostras coletadas na segunda etapa conforme procedimento descrito no apêndice I.

\section{6 - DETERMINAÇÃO QUALITATIVA E QUANTITATIVA}

As determinaçōes qualitativas de AM e AFM em amostras de urina foram realizadas pela comparação do tempo de retenção do pico dos analitos em soluções padrões, analisadas sob as mesmas condições analíticas. Em algumas determinações, as identificações do $\mathrm{AM}$ e do $\mathrm{AFM}$ foram realizadas adicionando padrões às amostras e comparando os cromatogramas ou eletroferogramas com aqueles obtidos sem adição dos padrões. O pico da espécie de interesse apresenta a área aumentada.

As determinações quantitativas foram realizadas pelos métodos da calibração externa ou pelo método da adição de padrão. O limite de detecção foi assumido como sendo o sinal do "branco" mais três vezes a estimativa do desvio 
padrão do "branco". O sinal do "branco" é tomado como o valor da intercepção da curva analítica. Assim, o limite de detecção foi sempre calculado a partir das curvas analíticas construídas a partir das média das áreas dos picos dos analitos em soluções padrões. Os cálculos envolvidos na determinação do limite de detecção e nas determinações quantitativas foram baseados em Miller \& Miller (1993).

\section{1 - Método da calibração externa}

O método quantitativo da calibração externa compara a área da substância problema na amostra com as áreas obtidas desta mesma substância em amostras com concentrações conhecidas (Collins \& Braga, 1987). Para cada componente da amostra cuja concentração se deseja determinar são construídos gráficos de área ou altura contra concentração de soluções padrões. A melhor curva que correlaciona estes pontos em cada gráfico é chamada de curva analítica. A composição das soluções padrōes deve ser próxima à da amostra, as concentrações devem cobrir a faixa desejada e elas devem ser analisadas sob as mesmas condições que a amostra. A concentração dos componentes da amostra é calculada através da equação: $C_{i}=\left(A_{i}-\right.$ b) $x R_{f}$, onde $A_{i}$ é a área do pico do componente de interesse presente na amostra, b é o coeficiente linear da curva analítica e $R_{f}$ é o inverso do coeficiente angular desta curva (Coutrim, 1991).

A exatidão deste método quantitativo depende da injeção de volumes idênticos de amostras e de soluções padrões adequadamente preparadas. Análises por HPLC utilizam o sistema de introdução da amostra através de válvulas de injeção com alça de amostragem de volume fixo permitindo minimizar os desvios na repetibilidade das injeções. Assim, a calibração externa se apresenta como um método adequado para análises por HPLC.

$\mathrm{Na}$ avaliação dos métodos de normalização de área, normalização de área com fator de resposta, padronização interna e calibração externa para a quantificação de derivados de aldeídos e cetonas separados por HPLC e detectados por UVvisível, o método de calibração externa apresentou os menores erros para a exatidão da análise e a estimativa do desvio padrão, relacionada com a repetibilidade, foi igual a 1,4\% (Coutrim et al., 1993).

Através do coeficiente de correlação dos pontos da curva analítica é possível 
avaliar a resposta do detector para o analito em questão na faixa de concentração desejada. Coeficientes maiores que 0,9 são normalmente aceitos para esta determinação.

Neste trabalho todas as determinações quantitativas por HPLC e algumas por $\mathrm{CE}$ foram realizadas pelo método da calibração externa e os coeficientes das curvas analíticas foram, na maioria das vezes, maior do que 0,99 .

\section{2 - Método da adição de padrão}

Muitas vezes, o sinal de resposta do detector não apresenta linearidade na faixa de concentração de interesse, ou o sinal não é reprodutivel, ou há variação no tempo de retenção, ou ainda, o sistema de injeção não permite introdução de volumes exatamente iguais de amostra. Nestes casos, para a determinação quantitativa, o método da adição de padrão é mais adequado do que o da calibração externa.

Neste trabalho, a maioria das determinações de AM por CE foram realizadas pelo método da adição de padrão devido as diferenças encontradas nos tempos de migração do $\mathrm{AM}$ na solução padrão e na amostra. $\mathrm{O}$ sistema de injeção por pressão ou voltagem em $\mathrm{CE}$ apresenta maiores problemas de repetibilidade do que o sistema de injeção em HPLC.

O método da adição de padrão consiste em analisar uma amostra pela técnica escolhida e, posteriormente, analisar a mesma amostra com quantidades conhecidas de padrão adicionadas à ela, sob as mesmas condições. Um gráfico da área ou altura do pico do analito contra a concentração do padrão adicionado é construído. A área ou altura do pico do analito na amostra sem adição de padrão corresponde à concentração zero no gráfico. Quanto maior o número de pontos no gráfico, maior a precisão da determinação. A curva resultante é ajustada e a concentração, em módulo, determinada por esta curva através da área ou altura zero, representa a concentração da espécie na amostra. Teoricamente é possível determinar a concentração com uma única adição de padrāo, pois a curva é obtida com dois pontos, um relativo à amostra e o outro à amostra com padrão. Na prática, no entanto, determinaçōes com menos de duas adiçōes não apresentam resultados confiáveis. 
Neste trabalho, o método em questão foi utilizado com adiçōes de padrão a duas, ou a três, ou mesmo a quatro diferentes concentrações. As análises que apresentaram coeficiente de correlação da curva resultante menor do que 0,9 não foram consideradas.

\section{3 - Limite de detecção (LD)}

Não há um consenso para a utilização de um único método para a determinação do limite de deteç̧ão em quantificações analíticas e muitos termos são utilizados para determinar esta grandeza: limite de detecção do instrumento (LDI), menor limite de detecção, limite de detecção do método (LDM) e limite de quantificação. O LDI está relacionado com a leitura do menor sinal do detector atribuído à presença do analito. O valor do LDM é considerado duas vezes o do LDI. O menor limite de detecção ou, simplesmente, limite de detecção (LD) é a menor quantidade ou concentração do analito que pode ser distinguida do branco (matriz sem analito) com uma confiança razoável. A confiança é caracterizada pelo risco da deteç̧ão do analito quando este não está presente (falso positivo) ou pela não detecção quando estiver presente (falso negativo). O LD pode ser considerado igual a 2 ou 3 vezes o LDI (Kuselman \& Shenhar, 1995).

Há muitas maneiras para calcular o LD, desde métodos simples sem qualquer tratamento estatístico até outros com forte base estatística. O LD pode ser obtido a partir de uma inspeção visual do cromatograma ou outro tipo de registro de sinal obtido e calculado como três vezes o sinal do ruído, geralmente empregando a altura como parâmetro avaliado.

Uma outra maneira de obter o LD sem a inspeção visual do sinal detectado é através da estimativa do desvio padrão da "concentração zero" de uma curva analítica. Este ponto equivale ao sinal do branco. A determinação do LD através de uma curva analítica é adequada para algumas técnicas analíticas, como as que utilizam detecção espectroquímica conforme recomendado pela IUPAC (International Union of Pure and Applied Chemistry), mas não é para outras, como GC-MS, nos quais são propostos outros métodos para a determinação do LD (Casado et al., 1996).

Neste trabalho foi utilizado o limite de detecção calculado a partir da curva analítica como o valor da concentração, correspondendo ao ponto de intercepção da 
curva (sinal do branco) mais três vezes a estimativa do desvio padrão deste ponto (Miller $\mathcal{E}$ Miller, 1993). Para o método da adição de padrão, o limite de deteç̧ão foi calculado como a concentração correspondente a três vezes a estimativa do desvio padrão da intercepção da curva resultante da adição de padrões.

\section{7 - DETERMINAÇÃO DE AM EM AMOSTRAS DE URINA HUMANA POR HPLC-UV}

As condiçōes testadas para a separação de AM presente em amostras de urina humana por HPLC e detecção no UV foram aquelas descritas por Ducos et al. (1990), exceto a coluna analítica, a qual não havia disponível nos laboratórios. Em todas as eluições de AM efetuadas através de coluna RP-18 foi utilizada a pré coluna Shim-pack CLC-GRD-ODS 4.

\section{1 - Avaliação da sensibilidade da deteç̧ão do AM por HPLC-UV}

O espectro de absorção UV-visível de uma solução aquosa de AM na faixa entre $190 \mathrm{~nm}$ e $550 \mathrm{~nm}$ apresentou um máximo de absorção em $260 \mathrm{~nm}$.

O limite de deteç̧ão foi determinado através de uma curva analítica construída a partir de soluções padrões de AM com concentrações entre 1 e 1000 $\mu \mathrm{g} / \mathrm{L}$. As condiçōes cromatográficas empregadas foram: coluna analítica Shim-pack CLC-ODS; volume de injeção igual a $10 \mu \mathrm{L}$; fase móvel constituída de metanol/ácido acético $1 \%, v / v$, na proporção de 10:90, v/v, a uma vazão de 1 $\mathrm{mL} / \mathrm{min}$ e detecção UV a $260 \mathrm{~nm}$.

\section{2 - Extração de AM com éter dietílico}

O AM foi extraído da amostra de urina, com e sem fortificação com $100 \mu \mathrm{g} / \mathrm{L}$ de AM, através de extração líquido-líquido descrita por Bechtold et al. (1991). À 10 $\mathrm{mL}$ de cada amostra foram adicionados duas porções de $10 \mathrm{~mL}$ de éter dietilico. As fases etéreas foram combinadas e a solução resultante foi evaporada à $50^{\circ} \mathrm{C}$ até a secura. $\mathrm{O}$ resíduo foi diluído a $1 \mathrm{~mL}$ com água deionizada e a solução resultante foi filtrada através de unidade filtrante com membrana de $0,22 \mu \mathrm{m}$ e analisada por HPLC na condição descrita no item 6.1. 
7.3 - Extração de AM através de cartuchos contendo SAX

O AM foi extraído da urina através de cartuchos contendo resina tipo SAX conforme o seguinte procedimento:

1. condicionamento: $3 \mathrm{~mL}$ de metanol seguido de $3 \mathrm{~mL}$ de água deionizada;

2. aplicação da amostra: $1 \mathrm{~mL}$ de amostra de urina;

3. lavagem: $3 \mathrm{~mL}$ de uma solução de ácido acético $1 \%, \mathrm{v} / \mathrm{v}$;

4. eluição da fração contendo AM: $3 \mathrm{~mL}$ de uma solução de ácido acético $10 \%, \mathrm{v} / \mathrm{v}$.

A solução contendo o AM foi recolhida separadamente e avolumada para 5 $\mathrm{mL}$ com ácido acético $10 \%$, v/v. A solução final foi analisada por HPLC na condição descrita no item 6.1. Os mesmos procedimentos de extraçāo e análise das amostras de urina foram utilizados para as soluções padrões.

Com a finalidade de reutilizar o cartucho com SAX, foram feitas eluições para permitir a sua recuperação. Os cartuchos utilizados foram recuperados com 3 $\mathrm{mL}$ de solução de hidróxido de sódio $0,1 \mathrm{~mol} / \mathrm{L}, 3 \mathrm{~mL}$ de água, $3 \mathrm{~mL}$ de solução de ácido clorídrico $1 \mathrm{~mol} / \mathrm{L}$ e $3 \mathrm{~mL}$ de água, nesta ordem. Foram realizadas até 10 extraçōes de AM de uma amostra de urina fortificada com $500 \mu \mathrm{g} / \mathrm{L}$ de AM reutilizando o mesmo cartucho. Apesar dos bons resultados obtidos com até 3 reutilizações, estudos posteriores não confirmaram estes resultados e, assim, a idéia de recuperação dos cartuchos foi abandonada.

\section{4 - Avaliação das colunas analíticas}

Para otimização da separação do AM extraído da urina através de cartuchos contendo SAX foram avaliadas as seguintes colunas: Shim-pack CLC-ODS, Spherisorb S3PC18, Ultrasphere ODS e Hibar® RT 250-4.

As avaliaçōes foram realizadas na seguinte condição cromatográfica:

- volume de injeção: $10 \mu \mathrm{L}$;

- fase móvel: metanol/ácido acético 1\%,v/v;

- vazão da fase móvel: $1 \mathrm{~mL} / \mathrm{min}$;

- detecção UV: $260 \mathrm{~nm}$. 
Dos parâmetros cromatográficos, apenas a composição da fase móvel foi variada, empregando concentrações de metanol entre 5\% e 30\%,v/v, em condições isocráticas e por gradiente.

Algumas análises foram realizadas com eluição por gradiente para diminuição do tempo de análise sem interferência na separação. Com relação ao metanol, o gradiente consistiu em: $10 \%$ por 2 minutos, $10 \%$ a $30 \%$ em 1 minuto, $30 \%$ por 7 minutos, $30 \%$ a $70 \%$ em 1 minuto, $70 \%$ por 10 minutos, $70 \%$ a $10 \%$ em 2 minutos e $10 \%$ por 7 minutos. Utilizando esta programação de gradiente o tempo total da corrida foi de 30 minutos.

A coluna Hibar@ RT 250-4, semelhante à coluna Lichrosorb RP-18, 250 x 4,0 $\mathrm{mm}, \mathrm{dp}=5 \mu \mathrm{m}$, da Merck, utilizada por Ducos et al. (1990), apresentou melhores resultados para a separação do AM extraído, porém foi empregada em poucas análises. Não se obteve bons resultados com esta coluna utilizando eluição por gradiente.

A coluna mais utilizada neste trabalho foi a Ultrasphere ODS. Depois da coluna Hibar» RT 250-4, esta foi a coluna que melhor separou o AM em extratos de urina.

\section{5 - Determinações de AM em amostras de urina com a coluna Ultrasphere ODS}

O AM foi extraído de amostras de urina e analisado por HPLC com a coluna Ultrasphere ODS. Dez $\mu \mathrm{L}$ do extrato foram injetados na coluna e o AM foi eluído com metanol e ácido acético $1 \%, 10: 90, \mathrm{v} / \mathrm{v}$, à uma vazão de $1 \mathrm{~mL} / \mathrm{min}$, e detectado à $260 \mathrm{~nm}$. Alguns extratos de urina também foram analisados por HPLC utilizando a eluição por gradiente descrita no item 6.4.

As injeções foram realizadas em duplicatas e, em alguns casos, em triplicatas. O AM foi quantificado nestas análises pelo método da calibração externa e as curvas analíticas foram construídas a partir de soluções padrões de AM com concentrações entre 25 e $1000 \mu \mathrm{g} / \mathrm{L}$. 
7.6 - Determinações de AM em amostras de urina com a coluna Hibar® RT $250-4$

Algumas amostras de urina foram analisadas por HPLC utilizando a coluna Hibar $\otimes$ RT 250-4. O volume de injeção foi igual a $10 \mu \mathrm{L}$, a fase móvel foi constituída de metanol e ácido acético $1 \%, 10: 90, \mathrm{v} / \mathrm{v}$, à uma vazão de $1 \mathrm{~mL} / \mathrm{min}$ e a detecção foi à $260 \mathrm{~nm}$. As separaçōes cromatográficas foram realizadas em duplicatas e o AM foi quantificado pelo método da calibração externa. A curva analítica foi construída com soluções padrões contendo 50, 100, 200, 500 e $1000 \mu \mathrm{g} / \mathrm{L}$ de AM.

\section{8 - DESENVOLVIMENTO DE METODOLOGIA PARA A DETERMINAÇÃO DE AM EM URINA HUMANA POR CE, SEM A UTILIZAÇÃO DE MODIFICADOR ORGÂNICO}

As seguintes variáveis envolvidas na separação, identificação e quantificação do AM por CE-UV foram avaliadas: comprimento de onda de máxima absorção $\left(\lambda_{\max }\right)$; composição do eletrólito; capilar; sistema de injeção; temperatura do forno do equipamento e diferença de potencial aplicada para a migração da amostra.

\section{1 - Comprimento de onda de máxima absorção}

Para a determinação do comprimento de onda utilizado na detecção do AM em amostras de urina analisadas por $\mathrm{CE}$, os espectros $\mathrm{UV}$-visivel de soluções padrão de AM foram avaliados. O espectro UV-visível de uma solução de $10 \mathrm{mg} / \mathrm{L}$ de AM em água apresentou um $\lambda_{\max }$ em $262 \mathrm{~nm}(A=1,718)$, enquanto que o de uma solução de $A M$ em metanol na mesma concentração apresentou um $\lambda_{\max }$ em $260 \mathrm{~nm}$ (A = $1,749)$.

\section{2 - Composição do eletrólito}

Os seguintes tampões foram avaliados para serem utilizados como eletrólitos: fosfato de sódio $\mathrm{pH} 7,0$; borato de sódio $\mathrm{pH} \mathrm{9,0} \mathrm{e} \mathrm{pH} 10,0$; borato/fosfato de sódio $\mathrm{pH}$ 8,0 e acetato de sódio $\mathrm{pH} 4$,5. A otimização da composição do eletrólito para a separação do AM por CE-UV foi realizada em amostras de urina com e sem fortificação com AM padrão, empregando os parâmetros eletroforéticos: 
- capilar: silica fundida com cela ótica de alta sensibilidade (capilar em " $z$ ");

- eletrólito: tampão com CTAB 0,1 mmol/L;

- injeção: eletrocinética (-30 kV aplicados durante 1 segundo);

- temperatura do forno do equipamento: $25^{\circ} \mathrm{C}$;

- diferença de potencial: $-30 \mathrm{kV}$;

- detecção: $262 \mathrm{~nm}$;

- limpeza do capilar: após cada análise, flush com o eletrólito durante 5 minutos com uma pressão negativa de 20 pol de $\mathrm{Hg}$.

O tampão que apresentou melhores resultados foi o fosfato de sódio $\mathrm{pH} 7,0 \mathrm{e}$ assim foi avaliada a concentração deste tampão no eletrólito na qual o AM apresentasse melhor separação. As concentrações avaliadas foram: 4,0; 8,0;12;40;60; 80 e $120 \mathrm{mmol} / \mathrm{L}$ de fosfato de sódio no eletrólito e os melhores resultados foram obtidos com o eletrólito na composição: tampão fosfato de sódio $\mathrm{pH}$ 7,0 a $60 \mathrm{mmol} / \mathrm{L}$ com CTAB a $0,1 \mathrm{mmol} / \mathrm{L}$.

\section{3 - Capilar}

Dois tipos de capilares com diâmetro interno igual a $75 \mu \mathrm{m}$ foram avaliados, o capilar comum e outro com cela de deteç̧ão de alta sensibilidade (capilar em " $z$ "). O sinal do AM obtido com o segundo capilar foi cerca de dez vezes maior do que com o primeiro capilar sob a mesma condição analítica.

\section{4 - Sistema de injeção}

Dois sistemas de injeção disponíveis no equipamento foram avaliados, injeção por pressão (pneumático) e por voltagem (eletrocinético). No sistema pneumático foi aplicada uma pressão de 5 polegadas de mercúrio (pol de $\mathrm{Hg}$ ) durante diferentes tempos, enquanto que no sistema eletrocinético foram aplicadas diferentes voltagens em diferentes tempos. Assim, foram avaliados:

- tempo de aplicação da pressão: 1, 2, 3, 4 e 5 segundos;

- voltagem: $-5,-10,-15,-20$ e $-30 \mathrm{kV}$;

* tempo de aplicação da voltagem: 1, 2, 3, 4, 5 e 10 segundos.

A comparação entre os dois sistemas de injeção foi feita pela avaliação do sinal obtido para o pico do $\mathrm{AM}$, pela repetibilidade dos resultados para uma mesma 
solução padrão e pela estimativa do desvio padrão da curva analítica construída a partir de soluções padrões de AM em diversas concentraçōes. Também foi avaliada a possibilidade de obtenção de curvas analíticas a partir de uma mesma solução padrão injetada em diferentes tempos.

\section{5 - Temperatura e voltagem aplicadas}

A temperatura do forno do equipamento e a voltagem aplicada para a migração foram avaliadas utilizando o capilar em " $z$ ", o eletrólito constituído de tampão fosfato de sódio $\mathrm{pH} 7,0$ a $60 \mathrm{mmol} / \mathrm{L}$ e CTAB a 0,1 mmol/L, e introduzindo a amostra durante 1 segundo com uma pressão igual a 5 pol de $\mathrm{Hg}$. Foram avaliadas as temperaturas de $20^{\circ} \mathrm{C}, 25^{\circ} \mathrm{C}$ e $30^{\circ} \mathrm{C}$, e as diferenças de potencial iguais a $-20,-25 \mathrm{e}$ $-30 \mathrm{kV}$.

\section{6 - Repetibilidade e recuperação do método}

Para a avaliação da repetibilidade do método uma amostra de urina de indivíduo não fumante foi fortificada com $500 \mu \mathrm{g} / \mathrm{L}$ de AM. As amostras, fortificada e não fortificada, foram analisadas em duplicatas por $\mathrm{CE}$ em três dias consecutivos empregando a condição otimizada descrita a seguir:

- capilar: sílica fundida com cela ótica de alta sensibilidade (capilar em " $z$ ");

- eletrólito: solução com tampão fosfato de sódio pH 7,0 a $60 \mathrm{mmol} / \mathrm{L}$ e CTAB a $0,1 \mathrm{mmol} / \mathrm{L}$;

- injeção: pneumática (pressão negativa de 5 pol de $\mathrm{Hg}$ aplicada durante 1 segundo);

- temperatura do forno do equipamento: $25^{\circ} \mathrm{C}$;

- diferença de potencial para a migração: $-30 \mathrm{kV}$;

- deteç̧ão: $262 \mathrm{~nm}$;

- limpeza do capilar: após cada análise, flush do eletrólito com uma pressão negativa de 20 pol de $\mathrm{Hg}$ aplicada durante 5 minutos.

A repetibilidade foi determinada a partir das áreas e alturas dos picos de AM nos eletroferogramas.

A recuperação do método foi avaliada adicionando $100 \mu \mathrm{g} / \mathrm{L}$ e $500 \mu \mathrm{g} / \mathrm{L}$ de AM em 5 amostras de urina. Estas amostras foram analisadas em triplicatas e as 
concentrações de AM foram determinadas pelo método da calibração externa utilizando uma curva analítica construída a partir das médias das áreas dos picos de AM de cinco soluções padrões com concentrações entre 100 e $500 \mu \mathrm{g} / \mathrm{L}$.

\section{7 - Determinação de AM em amostras de urina}

As amostras de urina foram apenas filtradas e, em seguida analisadas por CE. As determinações foram realizadas em triplicatas. Após 8 determinações o eletrólito era renovado com solução recentemente preparada.

A identificação do AM em todas as amostras de urina foi realizada pela adição de padrão. Cinco soluções padrões de AM de concentrações entre 100 e 500 $\mu \mathrm{g} / \mathrm{L}$ foram analisadas em duplicatas diariamente.

A quantificação do AM em amostras de urina de fumantes foi realizada pelo método da calibração externa. Uma curva analítica com concentraçōes de AM entre 100 e $500 \mu \mathrm{g} / \mathrm{L}$ foi construída a partir dos resultados de três dias, empregando seis determinações para cada concentração. A partir desta curva a concentração de AM foi determinada em todas as amostras de urina pelo método da calibração externa.

No entanto, foi constatado que a faixa de concentração de AM da curva analítica não englobava todos os valores de concentração de AM nas amostras de urina de indivíduos não fumantes. Desta forma, a quantificação do AM nestas amostras de urina também foi realizada pelo método da adição de padrão. Foram adicionados 100 e $500 \mu \mathrm{g} / \mathrm{L}$ de AM a cada amostra, as quais foram analisadas em triplicatas. As concentraçōes de AM, nesta ocasião, nāo foram corrigidas pelo teor de creatinina na urina.

\section{9 - DESENVOLVIMENTO DE METODOLOGIA PARA A DETERMINAÇÃo DE}

\section{AM EM URINA HUMANA POR CE COM A UTILIZAÇÃo DE MODIFICADOR ORGÂNICO}

Com o objetivo de obter condições de análise mais estáveis foi avaliada a utilização de modificador orgânico. Foram avaliados vários solventes orgânicos adicionados ao eletrólito em diversas concentrações, inclusive a adição de mistura de dois solventes. 


\section{1 - Escolha do modificador orgânico}

Utilizando capilares comuns, com $75 \mu \mathrm{m}$ ou $50 \mu \mathrm{m}$ de diâmetro interno, foi avaliada a adição dos seguintes modificadores orgânicos ao eletrólito:

- metanol à concentrações entre 10 e 30\%;

- acetonitrila à concentrações entre 5 e $20 \%$;

- N,N-dimetilformamida (DMF) à concentração de $10 \%$;

- mistura de metanol e acetonitrila, à diversas concentrações;

- mistura de metanol e dimetilformamida, à diversas concentrações.

\section{2 - Repetibilidade das injeções de amostra}

Para o estudo da repetibilidade das injeções, 4 amostras de urina foram fortificadas com $500 \mu \mathrm{g} / \mathrm{L}$ de AM padrāo. Estas amostras foram analisadas em quadruplicata em um dia e em triplicata em outro dia sob a seguinte condição otimizada:

- capilar: comum, de sílica fundida, com diâmetro interno igual a $50 \mu \mathrm{m}$;

- eletrólito: solução constituída de tampão fosfato de sódio $\mathrm{pH} 7,0$ a 120 $\mathrm{mmol} / \mathrm{L}, \mathrm{CTAB}$ a $0,4 \mathrm{mmol} / \mathrm{L}$ e metanol a $10 \%, \mathrm{v} / \mathrm{v}$;

- injeção: pneumática (pressão negativa de 5 pol de $\mathrm{Hg}$ aplicada durante 20 segundos);

- temperatura do forno do equipamento: $25^{\circ} \mathrm{C}$;

- diferença de potencial: $-20 \mathrm{kV}$;

- detecção: $260 \mathrm{~nm}$;

- tempo de análise: 10 minutos

- flush com o eletrólito para a limpeza do capilar: durante 3 minutos com uma pressão negativa de $20 \mathrm{pol}$ de $\mathrm{Hg}$ após cada análise.

A área do pico do AM obtido no eletroferograma foi determinada para cada amostra e a média das áreas das replicatas de um mesmo dia foi calculada. Pelas estimativas de desvio padrão das médias das replicatas foram avaliadas as variações ocorridas em um mesmo dia e em dias diferentes. 


\section{3 - Recuperação do método}

Para o estudo da recuperação do método foi escolhida uma amostra de urina contendo baixo teor de AM, a qual foi fortificada com $102 \mu \mathrm{g} / \mathrm{L}, 765 \mu \mathrm{g} / \mathrm{L}$ e 3060 $\mu \mathrm{g} / \mathrm{L}$ de AM padrão. As concentrações de AM nestas amostras foram determinadas pelo método da adição de padrão em duplicata na condição otimizada, a partir das seguintes adições:

- água e $\mathrm{AM}$ a 75, 250 e $500 \mu \mathrm{g} / \mathrm{L}$ na amostra original e na amostra fortificada com $102 \mu \mathrm{g} / \mathrm{L}$ de $\mathrm{AM}$;

- água e AM a 500, 1000 e $2000 \mu \mathrm{g} / \mathrm{L}$ na amostra fortificada com $765 \mu \mathrm{g} / \mathrm{L}$ de AM;

- água e AM a 1000, 2000 e $5000 \mu \mathrm{g} / \mathrm{L}$ na amostra fortificada com $3060 \mu \mathrm{g} / \mathrm{L}$ de AM.

Os resultados das concentrações de AM obtidas destas determinaçōes foram comparados com os valores previamente conhecidos.

\section{4 - Determinação de AM em amostras de urina}

O AM em amostras de urina foi determinado em duplicata utilizando a condição analítica otimizada. O eletrólito contido no reservatório do equipamento foi trocado por um outro recentemente preparado após 4 a 8 determinações. As curvas analíticas foram construídas a partir das áreas dos picos do AM em 8 soluções padrões com concentraçōes entre 50 e $1000 \mu \mathrm{g} / \mathrm{L}$. O AM foi quantificado nestas amostras utilizando o método da adição de padrão com adiçōes de água (concentração de $\mathrm{AM}=0 \mu \mathrm{g} / \mathrm{L}$ ) e soluções de AM a 250, 500, 1000 e $2500 \mu \mathrm{g} / \mathrm{L}$. As análises foram realizadas em duplicatas.

\section{0 - DETERMINAÇÃO DE ÁCIDO S-FENILMERCAPTÚRICO (AFM) EM AMOSTRAS DE URINA HUMANA POR CE}

Várias condições foram avaliadas para o estabelecimento de uma metodologia analítica para a determinação de AFM na urina por $C E$, inclusive a determinação simultânea de AFM e AM. 
10.1 - Separação de AFM da urina sem extração prévia

Na avaliação das condições analíticas para a separação de AFM na urina por CE foram empregadas: solução padrão de AFM com concentraçāo igual a $1 \mathrm{mg} / \mathrm{L}$, amostra de urina humana e amostras fortificadas com $1 \mathrm{mg} / \mathrm{L}$ e $10 \mathrm{mg} / \mathrm{L}$ de AFM padrão. Os parâmetros analíticos avaliados foram:

- capilar: comum, de sílica fundida, com $75 \mu \mathrm{m}$ ou $50 \mu \mathrm{m}$ de diâmetro interno;

- eletrólito: tampão fosfato de sódio com modificador orgânico e CTAB a 0,4 $\mathrm{mmol} / \mathrm{L}$;

- concentração do tampão: $72,90,96$ e $120 \mathrm{mmol} / \mathrm{L}$;

- $\quad$ pH do tampão fosfato de sódio: 3,$0 ; 4,0 ; 5,0 ; 6,0 ; 7,0 ; 8,0$ e 9,0;

- injeção da amostra: pneumática com pressão negativa de 5 pol de $\mathrm{Hg}$ aplicada durante 10 ou 20 segundos;

- voltagem para migração: $-20 \mathrm{kV}$ e $-25 \mathrm{kV}$;

- comprimento de onda: 214 e $254 \mathrm{~nm}$;

- modificadores orgânicos:

- metanol: 4,10 e $15 \%$;

- acetonitrila: $10 \%$;

- DMF: 10\%;

- metanol e acetonitrila: 10 e 10\%, 15 e 10\%, 10 e $20 \%, 20$ e $10 \%$, respectivamente;

- DMF e metanol: 10 e $10 \%, 10$ e $20 \%, 20$ e $10 \%$, respectivamente.

A melhor condição para a separação do AFM foi obtida com o capilar de 50 $\mu \mathrm{m}$ de diâmetro interno. O eletrólito foi constituído de tampão fosfato de sódio $\mathrm{pH}$ 7,0 a $90 \mathrm{mmol} / \mathrm{L}$, metanol a $10 \%$, DMF a $10 \%$ e CTAB a $0,4 \mathrm{mM}$. A amostra foi injetada durante 10 segundos, a migração ocorreu sob uma voltagem de $-20 \mathrm{kV}$ à $25^{\circ} \mathrm{C}$ e a detecção à $254 \mathrm{~nm}$. A quantificação do AFM não foi feita em função da separação insatisfatória do AFM em relação à outras espécies na urina.

10.2 - Separação de AFM extraído da urina com Sep-Pak» C18

O AFM foi extraído da urina conforme o procedimento descrito por Einig \& Dehnen (1995). O cartucho Sep-Pak» contendo $500 \mathrm{mg}$ de octadecilsilano foi 
condicionado com $5 \mathrm{~mL}$ de metanol e $10 \mathrm{~mL}$ de ácido acético 1\%, v/v. Em seguida, 2 $\mathrm{mL}$ de urina foram passados através dele e, o AFM foi eluído do cartucho com $2 \mathrm{~mL}$ de uma solução de metanol e acetato de amônio 0,1 mol/L, pH 7,0 (80:20, v/v). Os parâmetros analíticos avaliados para a separação por CE do AFM extraído, foram:

- capilar: comum com $75 \mu \mathrm{m}$ de diâmetro interno e capilar em " $z$ ";

- eletrólito: tampão com modificador orgânico e CTAB a 0,4 mmol/L;

- tampão: fosfato de sódio pH 7,0 a diversas concentrações, tetraborato de sódio $\mathrm{pH} \mathrm{9,4} \mathrm{a} 121 \mathrm{mmol} / \mathrm{L}$ e pH 9,0 a $40 \mathrm{mmol} / \mathrm{L}$ e tampão acetato de sódio $\mathrm{pH} \mathrm{4,2} \mathrm{a} 315 \mathrm{mmol} / \mathrm{L}$;

- concentração do tampão fosfato de sódio pH 7,0: 60, 72, 120 e $240 \mathrm{mmol} / \mathrm{L}$;

- modificador orgânico: metanol a 10\%; mistura de DMF e metanol a $10 \%$ cada;

- introdução da amostra: pneumática com uma pressão negativa de 5 pol de $\mathrm{Hg}$ aplicada por 10 segundos ou 20 segundos;

- voltagem para a migração: -20 e $-25 \mathrm{kV}$;

- temperatura do compartimento do capilar: 25 e $27^{\circ} \mathrm{C}$;

- comprimento de onda: 214 e $254 \mathrm{~nm}$.

\section{3 - Separação de AFM extraído da urina com resina SAX}

A extração do AFM da urina com resina tipo SAX foi avaliada em várias matrizes: uma solução aquosa padrão contendo $1 \mathrm{mg} / \mathrm{L}$ de $\mathrm{AM}$ e $1 \mathrm{mg} / \mathrm{L}$ de AFM; uma amostra de urina de fumante e outra de não fumante; uma amostra de urina de não fumante fortificada com $1 \mathrm{mg} / \mathrm{L}$ de $\mathrm{AFM}$ padrão. Os cartuchos Bond Elut ${ }_{\odot}$ contendo $500 \mathrm{mg}$ de resina SAX foram condicionados com $3 \mathrm{~mL}$ de metanol e $3 \mathrm{~mL}$ de água. Em seguida, $1 \mathrm{~mL}$ de amostra foi passado através do cartucho, o qual foi lavado com ácido acético 1\%,v/v. O AFM foi eluído do cartucho com $3 \mathrm{~mL}$ de ácido acético $10 \%, \mathrm{v} / \mathrm{v}$. As análises por HPLC das frações mostraram que o AFM estava presente somente na fração com ácido acético a $10 \%$. Após a adição de $3 \mathrm{~mL}$ de acetato de etila à solução de ácido acético contendo AFM, a mistura foi agitada e mantida em repouso várias vezes, durante 5 minutos. A fase orgânica foi evaporada até secura e o sólido foi redissolvido em $500 \mu \mathrm{L}$ de tampão fosfato de sódio $\mathrm{pH}$ 7,0 com concentração de $60 \mathrm{mmol} / \mathrm{L}$. 
Os extratos de AFM obtidos foram avaliados por CE por meio de um capilar comum de sílica fundida com $50 \mu \mathrm{m}$ de diâmetro interno. O eletrólito foi constituído de tampão fosfato de sódio $\mathrm{pH} \mathrm{7,0} \mathrm{a} 60 \mathrm{mmol} / \mathrm{L}$ e CTAB a 0,5 mmol/L. A amostra foi introduzida com pressão negativa de 5 pol de $\mathrm{Hg}$ por $20 \mathrm{~s}$ e voltagem de $-30 \mathrm{kV}$ à temperatura de $22^{\circ} \mathrm{C}$. O AFM foi detectado à $254 \mathrm{~nm}$. 


\section{RESULTADOS E DISCUSSÃO}

\section{1 - AVALIAÇĀO DA DETERMINAÇÃO DE BENZENO POR HPLC-UV E POR GC-FID}

Foi avaliada a possibilidade de determinar o benzeno urinário. A literatura descreve metodologias que empregam a técnica de headspace, estático ou dinâmico, ou purge and trap acoplados ao cromatógrafo a gás. Devido a não disponibilidade destes acessórios, foi avaliada a sensibilidade necessária para a determinação do benzeno em amostras de urina humana por cromatografia líquida (HPLC-UV) e gasosa (GC-FID). Na literatura são relatados níveis de limite de deteç̧ão para a determinação de benzeno urinário tão baixos quanto $50 \mathrm{ng} / \mathrm{L}$ obtido por Ghittori et al. (1993) com a técnica de purge and trap acoplado ao cromatógrafo a gás.

\section{1 - Avaliação da sensibilidade da deteç̧ão do benzeno por HPLC-UV}

As análises por HPLC de benzeno em soluções metanólicas, apresentaram cromatogramas com linha base instável. Este fato impediu que o benzeno pudesse ser detectado em soluções com concentrações abaixo de $44 \mu \mathrm{g} / \mathrm{L}$. Os resultados fizeram com que as avaliações por esta técnica fossem abandonadas.

\section{2 - Avaliação da sensibilidade da detecção do benzeno por GC-FID}

Também foi avaliada a possibilidade de analisar o benzeno por cromatografia gasosa com detecção por ionização em chama. Metanol, etanol e acetona foram testados como solvente para esta análise empregando colunas capilares com fases estacionárias com diferentes polaridades. Em nenhuma condição foi obtido uma boa separação entre o benzeno à baixas concentrações e o solvente. Apesar de obterem melhores resultados com o metanol e a coluna com fase estacionária mais polar (fenil polissiloxano), o benzeno não pode ser detectado em soluções cuja concentração foi inferior a $400 \mu \mathrm{g} / \mathrm{L}$. Esta técnica também foi abandonada e foi decidido não trabalhar com benzeno urinário neste projeto. 


\section{2 - COLETA DE URINA DE INDIVÍDUOS FUMANTES E NÃO FUMANTES}

As urinas de indivíduos voluntários, fumantes e não fumantes, foram coletadas para este trabalho em duas ocasiōes distintas. Na primeira, foram coletadas 11 amostras de indivíduos do sexo masculino e 9 do sexo feminino, sendo 9 de fumantes e 11 de não fumantes. A determinação do $\mathrm{AM}$ por $\mathrm{CE}$ foi realizada em 10 destas amostras uma semana após a coleta, e todas as amostras foram analisadas por HPLC seis meses depois. Na segunda etapa foram coletadas 32 amostras de urina, as quais foram analisadas entre uma semana e uma mês após a coleta. Uma amostra foi coletada 10 meses após esta etapa para comparação de metodologias.

A quantidade média de urina excretada diariamente por uma pessoa normal varia entre 1200 e $1500 \mathrm{~mL}$. Muitos compostos orgânicos e inorgânicos são eliminados do organismo humano através da urina. A composição desta matriz é muito complexa e variada. Além da uréia, que é eliminada em grande quantidade na urina, é possível encontrar cloreto ‘a uma concentração média em torno de $6 \mathrm{~g} / \mathrm{L}$ e fosfato em torno de 1,2 g/L (Wildman et al., 1991). Por outro lado, alguns compostos são encontrados em quantidades tão pequenas que apresentam problemas para a detecção, como o AFM.

A dieta alimentar fornece uma grande fonte de metabólitos os quais podem interferir drasticamente em análises de determinadas espécies na urina. A dieta é uma exposição tão complexa que uma avaliação completa de sua interferência em determinações urinárias exige estudos epidemiológicos nutricionais com boa validação (Wahrendorf, 1995).

A utilização de marcador biológico está sujeita a uma maior variabilidade do que as técnicas convencionais de avaliação da exposição, porque o corpo participa ativamente na recepção, distribuição e eliminação dos contaminantes absorvidos (Schulte $\mathcal{E}$ Talaska, 1995).

A Organização Mundial da Saúde alerta para as variáveis que podem confundir avaliações de resultados e que devem ser consideradas em estudos com marcadores biológicos, tais como, idade, sexo, raça, hábito de fumar e consumir bebidas alcoólicas, uso de drogas, fatores genéticos e problemas de saúde (WHO, 1995). Hábito de fumar, dirigir, ir a postos de gasolina e a lavanderias à seco antes de 
coletar amostras para um estudo de correlação entre a concentração de poluentes no ar ambiente e na respiração de indivíduos expostos, interferiram nos resultados obtidos (Wallace et al., 1985).

Neste estudo foi considerado importante ter informações sobre a ingestão de medicamentos e o hábito de fumar dos voluntários doadores de amostras de urina. Desta maneira, foi solicitado o preenchimento de um pequeno questionário (Apêndice II) durante a segunda etapa de amostragem. Este não teve como objetivo uma avaliação completa de todas as variáveis que poderiam influenciar nas determinações urinárias, mas auxiliou na compreensão da correlação do teor de AM urinário com a quantidade de cigarros fumados e na interpretação dos resultados de concentraçōes de AM urinário muito discrepantes. As informações obtidas pelos questionários foram agrupadas por sexo, idade, período da coleta e hábito de fumar e estão apresentadas na tabela IV. Foi constatado que 7 voluntários ingeriram algum tipo de medicamento, na maioria analgésicos, nas últimas 48 horas que antecederam a coleta.

TABELA IV - Classificação das amostras de urina por sexo, hábito de fumar, idade e período da coleta

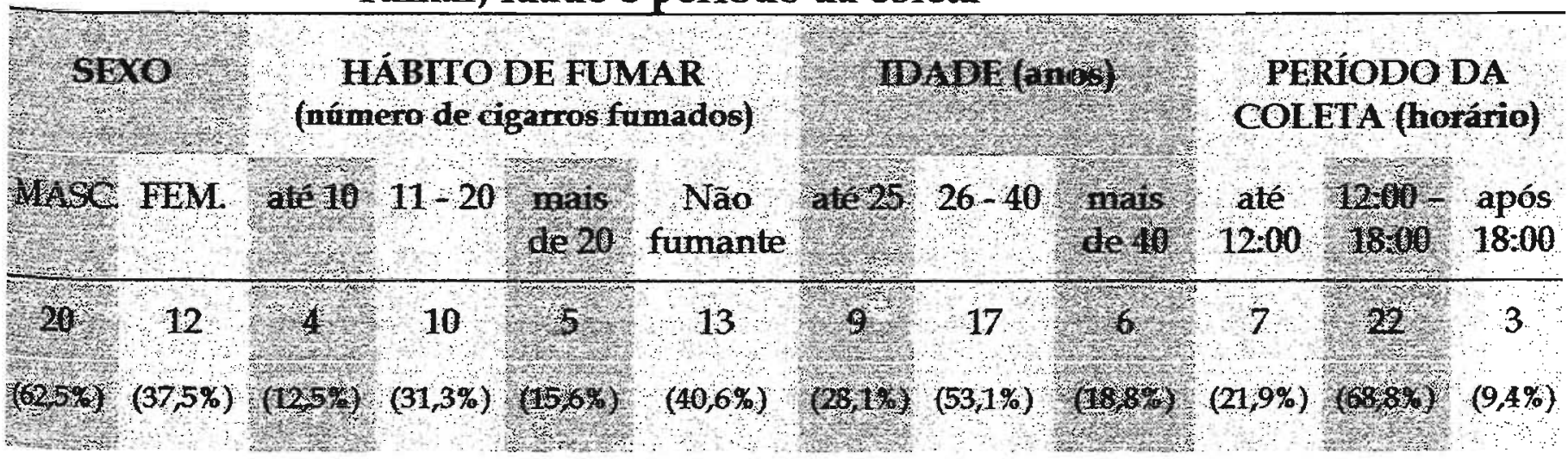

\section{3 - DETERMINAÇÃO DE AM EM AMOSTRAS DE URINA HUMANA POR HPLC-UV}

O AM (ácido trans,trans-hexa-2,4-dien-1,6-dióico) apresenta duas ligações duplas conjugadas que the confere alta absortividade molar devido ao aumento na 
diferença de energia entre os orbitais $\pi$ (ligantes), de menor energia, e os orbitais $\pi^{*}$ (antiligantes), de maior energia. Estes dois cromóforos, característica dos dienos conjugados, proporcionam grande sensibilidade às análises com deteç̧ão espectrofotométrica. O espectro UV-visível do AM apresenta um máximo de absorção à $260 \mathrm{~nm}$ e neste comprimento de onda é possível a detecção de quantidades muito pequenas do analito.

Na Figura 1 é apresentado o cromatograma de $10 \mu \mathrm{L}$ de uma solução padrão contendo $10 \mu \mathrm{g} / \mathrm{L}$ de AM. O sinal obtido no cromatograma representa a detecção de $7,04 \cdot 10^{-13}$ moles de AM. Através de uma inspeção visual do cromatograma é possível verificar que o sinal relativo ao AM é cerca de dez vezes maior do que o ruído, o que indica que quantidades ainda menores podem ser detectadas. 


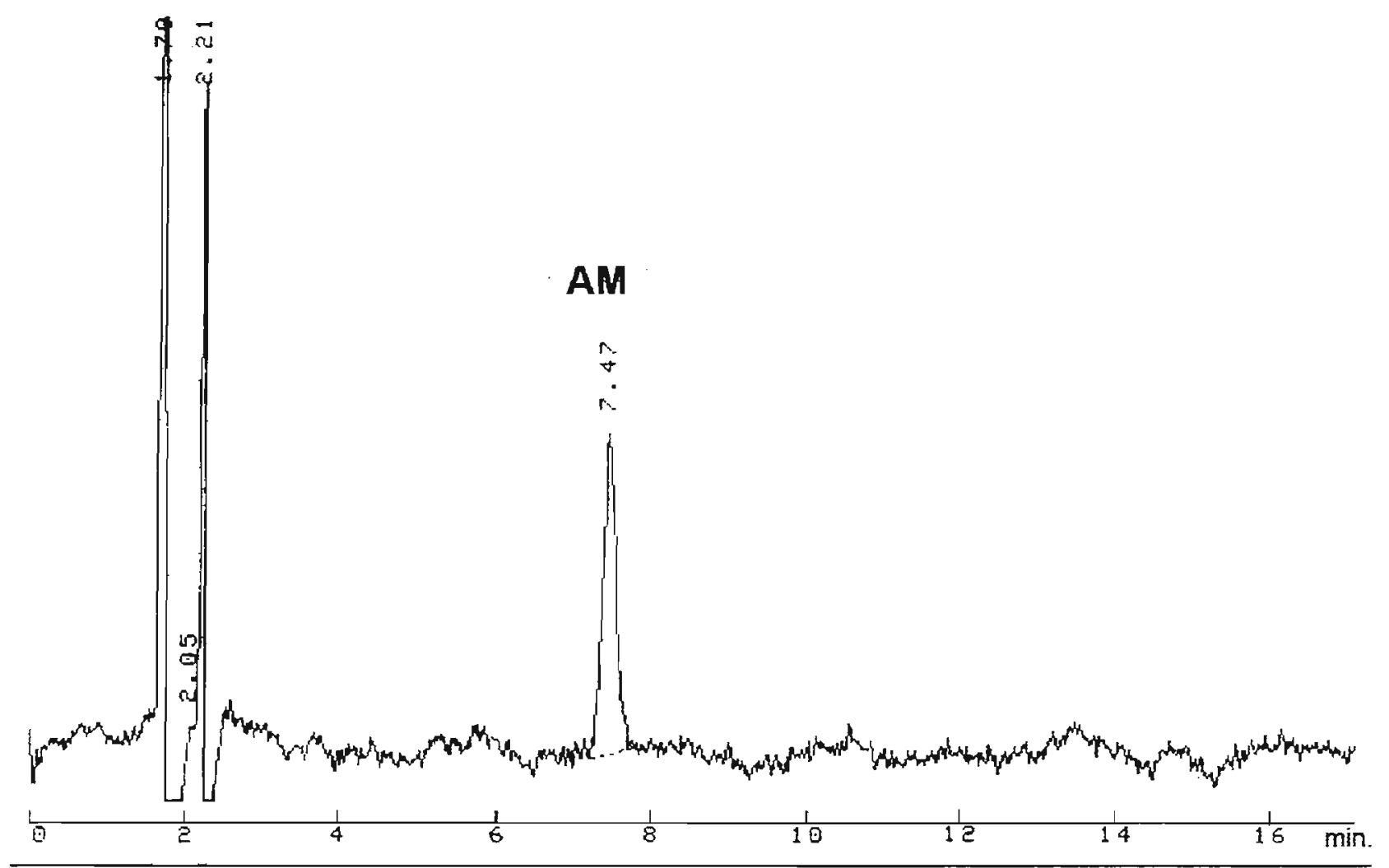

\section{$A M=A ́ C I D O M U C O ̂ N I C O$}

Figura 1 - Cromatograma de $10 \mu \mathrm{L}$ de uma solução padrão contendo $10 \mu \mathrm{g} / \mathrm{L}$ de $\mathrm{AM}$ (coluna analítica Shim-pack CLC-ODS; MeOH/HAc, 1\%, 10:90,v/v; vazão $=1 \mathrm{~mL} / \mathrm{min}$ e detecção $=260 \mathrm{~nm}$ ). 
As curvas analíticas para a determinações de LD e quantificaçōes por calibração externa foram construídas a partir de soluções aquosas dos padrões. Em um estudo quantitativo não foi encontrado diferença na comparação das áreas dos picos de AM proveniente de solução aquosa padrão e de amostra de urina com concentração equivalente de $\mathrm{AM}$, indicando que a matriz não interfere na resposta do detector (Bartczak et al., 1994).

Uma curva analítica de área contra concentração de AM, com sete pontos, construída a partir de soluções padrões de $\operatorname{AM}(1 ; 2,5 ; 5 ; 10 ; 50 ; 100$ e $1000 \mu \mathrm{g} / \mathrm{L})$, está apresentada na Figura 2. A condição analítica utilizada foi a mesma descrita na Figura 1. O LD calculado a partir desta curva foi igual a $5,8 \mu \mathrm{g} / \mathrm{L}$.

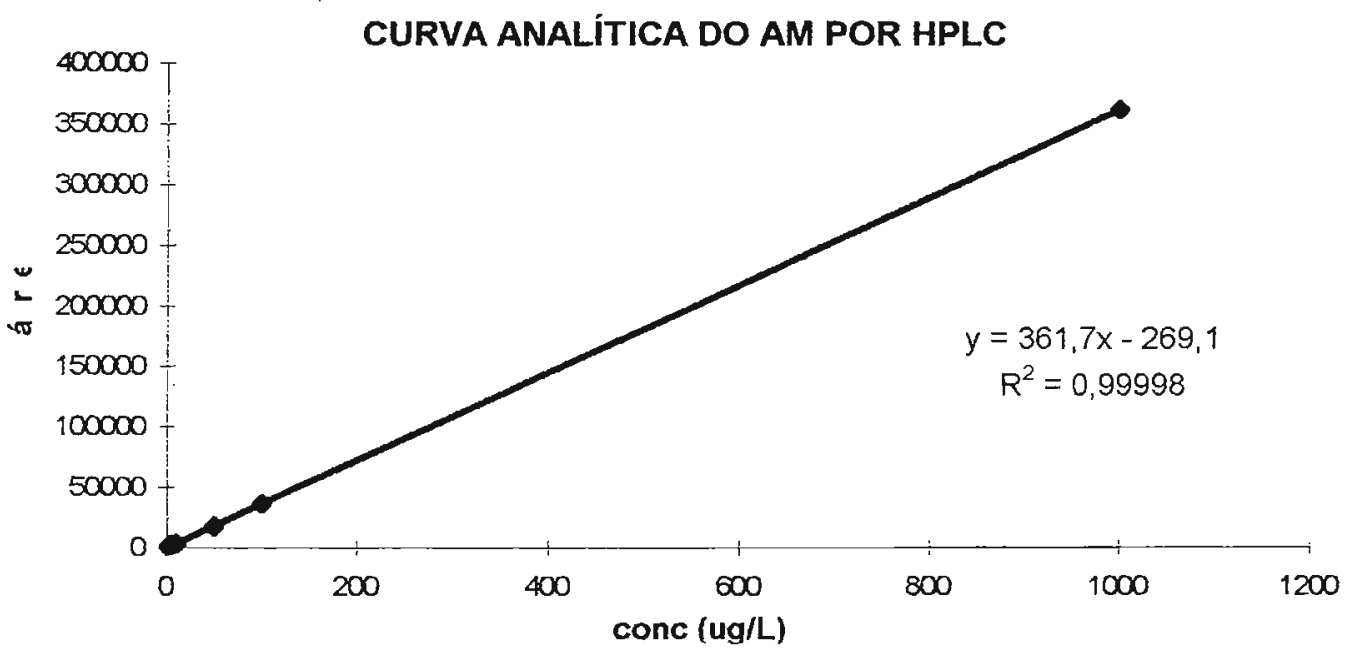

Figura 2 - Curva analítica de solucões padrões de AM com concentracões entre $1 \mu \mathrm{g} / \mathrm{L}$ e $1000 \mu \mathrm{g} / \mathrm{L}$, determinadas por HPLC.

\section{1 - Extracão do AM de amostras de urina}

Um grande problema encontrado na determinação de $\mathrm{AM}$ em urina por HPLC é a resoluçāo ruim do AM no cromatograma. A urina humana, por ser uma matriz muito complexa, torna a separação dos seus componentes uma tarefa difícil.

Uma filtração prévia através de filtros com poros de $2 \mu \mathrm{m}$ não foi suficiente para fracionar a amostra de urina, apesar do emprego de eluição por gradiente. $\mathrm{Na}$ 
Figura 3 são apresentados os cromatogramas de duas amostras de urina humana e de uma solução padrão com AM a $1000 \mu \mathrm{g} / \mathrm{L}$ analisadas por HPLC utilizando apenas uma filtração prévia do AM. É possível observar que nessas condições não houve separação do AM de outros componentes da urina. Análises de urina na qual a amostra é apenas filtrada necessita de um tempo maior para a linha base retornar ao estado inicial, mostrando a dificuldade para a eluição de alguns compostos retidos na coluna. Por outro lado, a injeção direta de amostras de urina em colunas analíticas diminui a vida útil das colunas (Ducos et al., 1990), constituindo uma desvantagem do método.

Para contornar os problemas relatados, foi necessário submeter a urina à uma extração prévia. Há dois procedimentos descritos na literatura para a extração do AM na urina, extração líquido-líquido (Bechtold et al., 1991) ou extração em fase sólida (Ducos et al., 1990). Os dois procedimentos foram testados neste trabalho.

A extração líquido-líquido do $\mathrm{AM}$, empregando éter dietílico, de uma amostra de urina de indivíduo não fumante e desta fortificada com $100 \mu \mathrm{g} / \mathrm{L}$ de AM foi realizada e as fraçōes resultantes foram analisadas por HPLC. Houve uma melhora na separação do $\mathrm{AM}$, mas a resolução foi baixa não permitindo a determinação quantitativa do AM. 


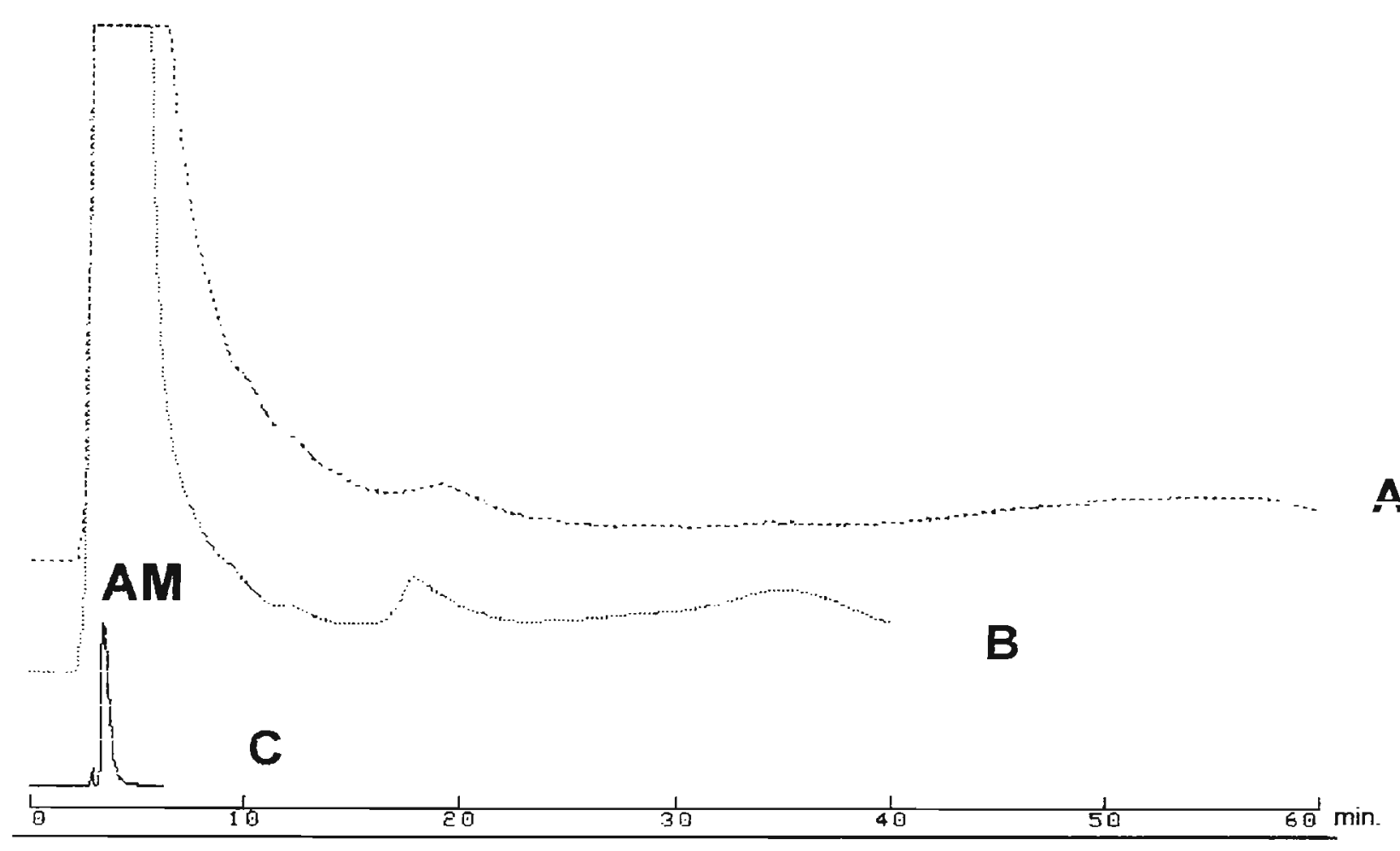

AMM = ÁCIDO MUCÔNICO

Figura 3 - Cromatogramas de amostras de urina sem tratamento prévio: A e B - urina; C - AM padrão $(1000 \mu \mathrm{g} / \mathrm{L})$. Condiçōes: injeção $=10 \mu \mathrm{L}$; coluna Shim-pack CLC-ODS; fase móvel $=\mathrm{MeOH} / \mathrm{HAc}$, $1 \%$; gradiente linear em relação ao metanol $=30 \%$ por $5 \mathrm{~min}$, de $30 \%$ a $70 \%$ em $25 \mathrm{~min}, 70 \%$ por $10 \mathrm{~min}$, de $70 \%$ a $30 \%$ em $20 \mathrm{~min}$; vazão = $1 \mathrm{~mL} / \mathrm{min}$; detecção $=260 \mathrm{~nm}$.

Para a extração em fase sólida do AM foi utilizado cartucho contendo resina tipo SAX. Na Figura 4 são apresentados os cromatogramas correspondentes à solução padrão de $\mathrm{AM}(\mathrm{B})$; amostra de urina de indivíduo não fumante (A); e esta fortificada com AM (C). 


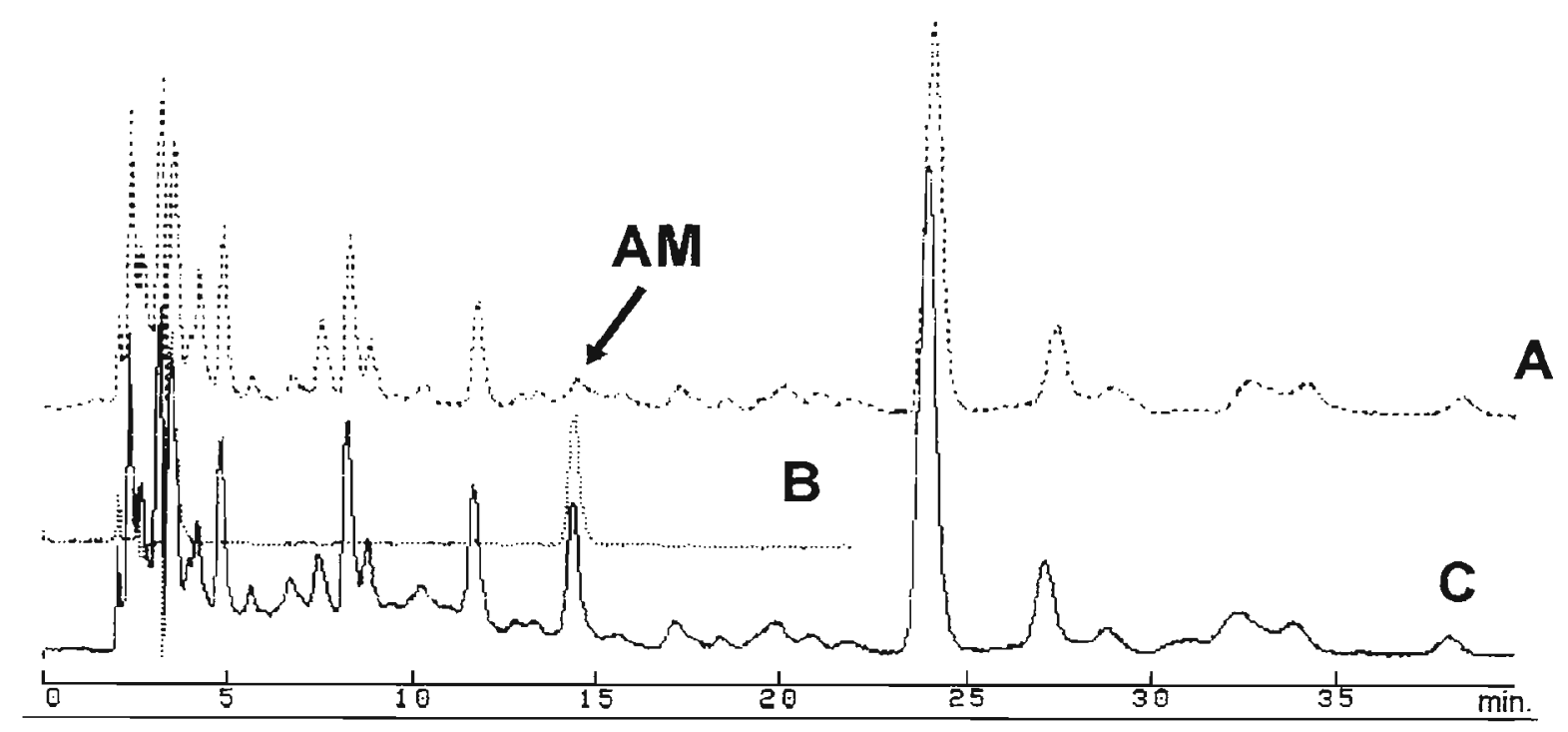

\section{AM = ÁCIDO MUCÔNICO}

Figura 4 - Cromatogramas de extratos eluídos de cartuchos com SAX: A - urina de indivíduo não fumante; $B$ - solução padxão de $A M$ a $500 \mu \mathrm{g} / \mathrm{L} ; \mathrm{C}$ - urina de indivíduo não fumante fortificada com $500 \mu \mathrm{g} / \mathrm{L}$ de $\mathrm{AM}$. Condições: volume injetado: $10 \mu \mathrm{L}$; coluna analítica: Hibar ${ }^{\$}$ RT 250-4; fase móvel: $\mathrm{MeOH} / \mathrm{HAc}$, 1\% (10:90,v/v); vazão: $1 \mathrm{~mL} / \mathrm{min}$; detecção: $260 \mathrm{~nm}$.

O estudo para verificar a possibilidade de reutilização dos cartuchos não foi conclusivo, pois os resultados obtidos (Tabela V) não foram suficientes para fornecer informações a respeito da condição destes após a regeneração. Desta forma, os cartuchos empregados para extrações de AM foram utilizados uma só vez. Porém, 
em estudo semelhante, estes cartuchos utilizados na extração de urina foram regenerados com solução de ácido clorídrico $2 \mathrm{~mol} / \mathrm{L}$ e reutilizados até dez vezes (Buratti et. al., 1996).

\section{TABELA V - Avaliação da reutilização dos cartuchos SAX pela área e altura do pico do AM em vários tipos de amostras}

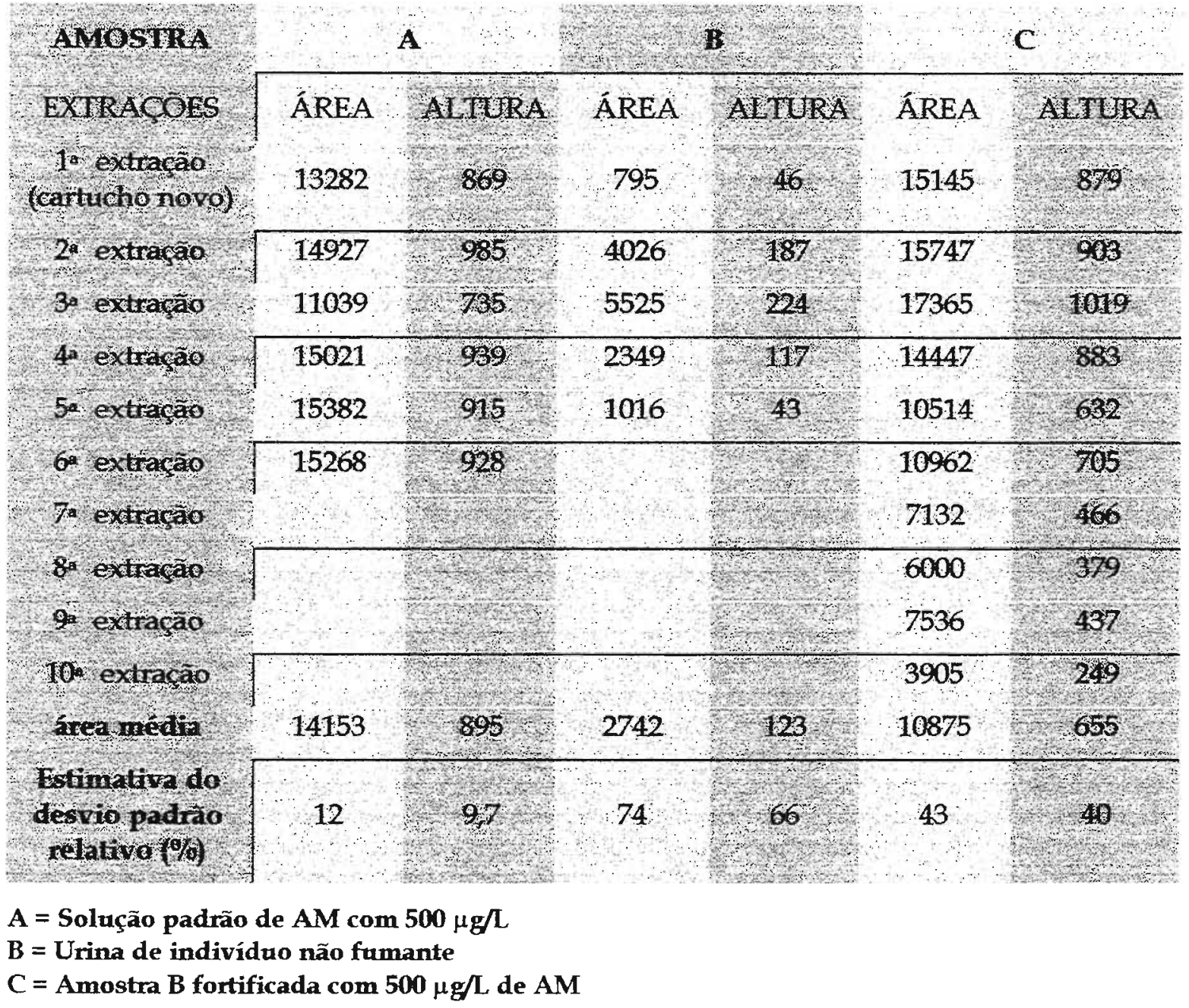

\section{2 - Determinação da concentração de creatinina nas amostras de urina}

O teor de AM urinário varia de amostra para amostra devido a vários fatores, tais como: concentração de benzeno inalado, característica individual do metabolismo e diluição da amostra. Como a diluição da urina é um problema para a comparação de resultados de análises de substâncias realizadas nesta matriz, tornase necessário corrigir esta interferência. Uma das maneiras de fazer esta correção é 
amostrar uma alíquota representativa da quantidade total da urina expelida por um indivíduo em 24 horas. Apenas uma amostra de urina nestas condições não é afetada por diluiçôes inconstantes sofridas durante a ingestão de líquidos ou na sudorese. No entanto, se a análise, como por exemplo, a determinação da concentração de IBE's for realizada em amostras pontuais de urina estas devem ter suas diluições corrigidas. Dentre os parâmetros utilizados para a correção da diluição da urina, a creatinina é uma medida freqüentemente utilizada. Sabe-se que a quantidade de creatinina excretada durante 24 horas por um determinado indivíduo é aproximadamente constante, proporcional à massa corpórea e pouco influenciada pela diurese (Alessio et al., 1985). Embora não seja necessário fazer este tipo de correção para o desenvolvimento de metodologia analítica, neste trabalho utilizou-se este fator para possibilitar a comparação de resultados de concentração de AM em urina de indivíduos fumantes e não fumantes e, também com valores da literatura. $\mathrm{O}$ teor de creatinina foi determinado em 33 amostras de urina, sendo 19 de indivíduos fumantes e 14 de não fumantes e os valores estão apresentados na Tabela VI. O teor de creatinina da amostra 64 é superior a três e portanto esta não pode ser utilizada para comparação de concentrações de AM entre as amostras analisadas (Alessio et al., 1985). 


\section{TABELA VI - Concentração de creatinina na urina de indivíduos fumantes e não fumantes.}

\begin{tabular}{|c|c|c|c|}
\hline AMOSTRA & $\begin{array}{l}\text { Creatinina em urina } \\
\text { de fumantes }(g / L)\end{array}$ & AMOSTRA & $\begin{array}{l}\text { Creatinina em urina de } \\
\text { não fumantes }(g / L)\end{array}$ \\
\hline 11 & 0,7 & 45 & 2,4 \\
\hline 42 & 1,4 & 52 & 1,6 \\
\hline 43 & 1,9 & 53 & $2 ; 2$ \\
\hline 44 & 1,7 & 55 & 0,6 \\
\hline 46 & 1,6 & 56 & 1,6 \\
\hline 47 & 1,0 & 57 & 2,1 . \\
\hline 48 & 1,4 & 60 & 0,8 \\
\hline 49 & 0,9 & 62 & 1,7 \\
\hline 50 & 0,9 & 64 & 3,8 \\
\hline 51 & 2,5 & 65 & 1,7 \\
\hline 54 & 2,6 & 68 & 0,6 \\
\hline 58 & 0,8 & 69 & 2,2 \\
\hline 59 & 0,9 & 70 & 1,4 \\
\hline 61 & 0,8 & 75 & 0,9 \\
\hline 63 & 2,2 & & \\
\hline 66 & 1,0 & & \\
\hline 67 & 1,1 & & \\
\hline 71 & 0,9 & & \\
\hline 72 & 0,9 & II & \\
\hline
\end{tabular}

\section{3 - Determinação de AM urinário com eluição isocrática}

Utilizando a coluna analítica Ultrasphere ODS, a concentração de AM foi determinada em extratos de 9 amostras de urina de fumantes e 11 não fumantes. $O$ teor de creatinina não foi determinado nestas amostras. A concentração do AM foi determinada pelo método da calibração externa a partir da curva analítica construída com soluções padrões de AM com concentraçōes entre $50 \mu \mathrm{g} / \mathrm{L}$ e $1000 \mu \mathrm{g} / \mathrm{L}$ (5 pontos obtidos da média de 5 replicatas). Os resultados, que representam a média de 
duplicatas ou triplicatas, estão apresentados na Tabela VII. Os cálculos foram realizados a partir das áreas do pico do AM. Em muitos cromatogramas, o AM apareceu na cauda de um pico maior, o que ocasionou valores de altura inferiores ou superiores aos valores reais dependendo do método de integração empregado. Além disso, estudos comprovam que as estimativas dos desvios padrōes das curvas analíticas construídas a partir das áreas dos picos são menores do que das curvas construídas a partir das alturas (Wätzig, 1995).

TABELA VII - Ácido mucônico urinário, em $\mu \mathrm{g} / \mathrm{L}$ de urina, determinado por HPLC com modo isocrático de eluição empregando a coluna Ultrasphere ODS

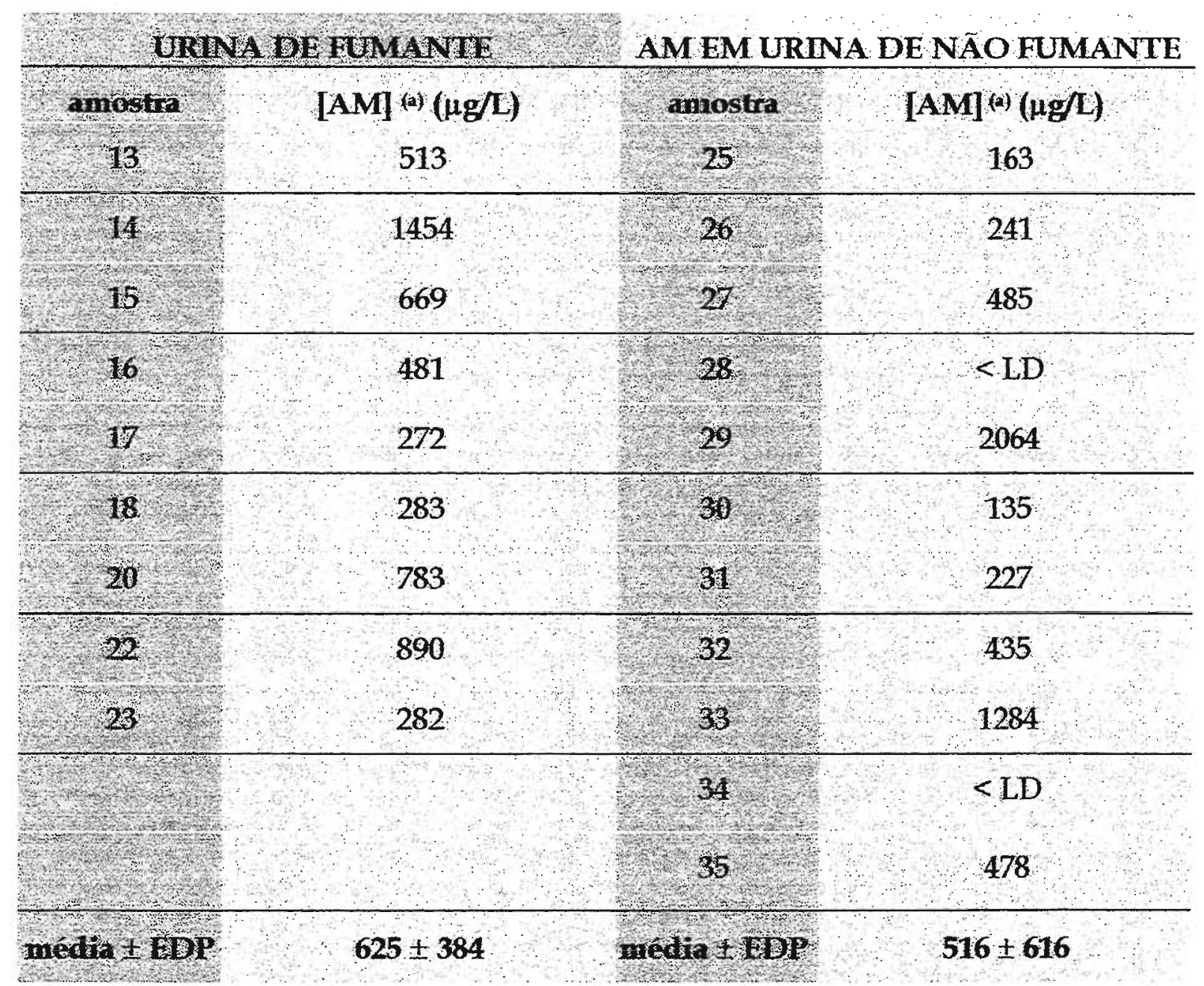

(a) Concentração determinada pelo método de calibração extema usando a área do pico.

$\mathrm{LD}=83 \mu \mathrm{g} / \mathrm{L}$.

EDP = Estimativa do desvio padrão. 
3.4 - Determinação de AM urinário com eluição isocrática em amostras com teores de creatinina conhecidos

Foi determinada a concentração de AM em 11 amostras de urina de fumantes e 4 nāo fumantes, as quais tinham o teor de creatinina conhecido, utilizando a coluna Ultrasphere ODS com eluição isocrática. A concentração de AM nestas amostras foi obtida pelo método da calibração externa através de curva analítica construída a partir de seis soluções padrões com concentrações entre 25 $\mu \mathrm{g} / \mathrm{L}$ e $1000 \mu \mathrm{g} / \mathrm{L}$. As determinações foram realizadas em duplicatas. Os valores obtidos para a concentração do $\mathrm{AM}$, em $\mu \mathrm{g} / \mathrm{L}$, foi dividido pela concentração de creatinina, em $\mathrm{g} / \mathrm{L}$, e os resultados foram expressos em microgramas de AM por grama de creatinina ( $\mu \mathrm{g} / \mathrm{g}$ creat). Estes resultados estão apresentados na Tabela VIII. 
TABELA VIII - Ácido mucônico na urina de indivíduos fumantes e não fumantes, em $\mu \mathrm{g} / \mathrm{g}$ de creat, determinado por HPLC com eluição isocrática e coluna Ultrasphere ODS

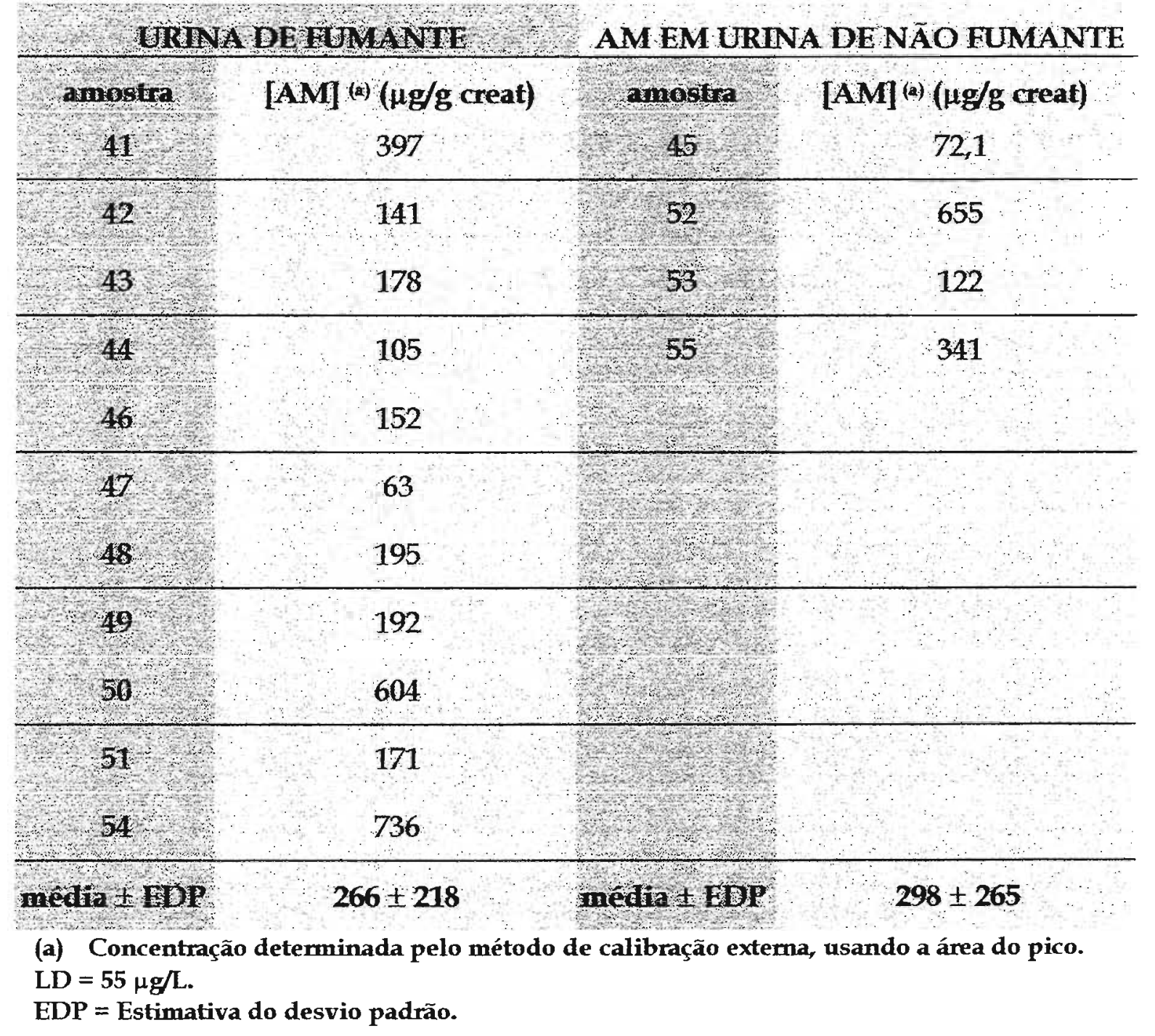

A concentração de AM por HPLC, utilizando a coluna analítica Hibar ${ }^{\circledR}$ RT 250-4 com eluição isocrática, foi determinada também em 6 amostras de urina, sendo 3 de fumantes e 3 de não fumantes, armazenadas a $-20^{\circ} \mathrm{C}$. Além destas amostras, a concentração de AM foi determinada em uma amostra de urina recém coletada de indivíduo não fumante e na mesma amostra fortificada com $500 \mu \mathrm{g} / \mathrm{L}$ de $\mathrm{AM}$ padrão. A quantificação do AM nestas amostras foi realizada através de uma curva analítica de 5 pontos com concentrações do AM variando entre $50 \mu \mathrm{g} / \mathrm{L}$ e $1000 \mu \mathrm{g} / \mathrm{L}$. Os resultados corrigidos pelo teor de creatinina estão apresentados na Tabela IX. 
TABELA IX - Ácido mucônico urinário, em $\mu \mathrm{g} / \mathrm{g}$ de creat, determinado por HPLC(a) com eluição isocrática empregando a coluna Hibar $\mathrm{RT}^{\text {(ब) }}$ 250-4

\begin{tabular}{|c|c|c|c|}
\hline UT & NA DE FUMA NTE & \multicolumn{2}{|c|}{$\begin{array}{c}\text { AM EM URTNA DE NĀO } \\
\text { FUMANTE }\end{array}$} \\
\hline amestra & {$[\mathrm{AM}]^{(b)}$ ( $\mu \mathrm{g} / \mathrm{g}$ creatinina) } & amostra & $[A M]]^{(b)}(\mu g / g$ creatinina) \\
\hline 46 & 60 & 55 & $<\mathrm{LD}$ \\
\hline 50 & 178 & 57 & 28 \\
\hline 58 & 122 & 62 & 63 \\
\hline & & 75 & 96 \\
\hline & & $75 / 50010$ & 596 \\
\hline
\end{tabular}

(a) Coluna analítica Hibar ${ }^{\oplus T}$ 250-4 (Menck).

(b) Concentração determinada pelo método de calibração extema usando a área do pico.

(c) Amostra de urina fortificada com $500 \mu \mathrm{g} / \mathrm{L}$ de $\mathrm{AM}$ padrão.

$\mathrm{LD}=54 \mu \mathrm{g} / \mathrm{L}$.

3.5 - Determinação de AM urinário com eluição por gradiente em amostras com teores de creatinina conhecidos

A concentração de AM foi determinada em 17 amostras de urina de indivíduos fumantes e em 9 de não fumantes com teores de creatinina conhecidos, utilizando a coluna Ultrasphere ODS com gradiente linear. Os resultados das concentraçōes de AM corrigidas pelo teor de creatinina estão apresentados na Tabela $X$. As concentrações de AM foram calculadas a partir da área do pico em razão do alargamento do pico, o qual nem sempre estava bem resolvido na linha de base. 
TABELA X - Ácido mucônico urinário, em $\mu \mathrm{g} / \mathrm{g}$ de creat, determinado por HPLC com eluição por gradiente empregando a coluna Ultrasphere ODS



3.6 - Comparação de resultados de concentrações de AM urinário por HPLC

Os resultados de concentração de AM nas amostras de urina determinados por HPLC por três procedimentos diferentes estão na Tabela XI. 
TABELA XI - Comparação dos resultados de concentração de ácido mucônico urinário determinado por HPLC

\begin{tabular}{|c|c|c|c|}
\hline amostma & $\begin{array}{c}\text { [AM] } \\
\text { (1)/g creat) }\end{array}$ & $\begin{array}{c}{[\mathrm{AM}]^{\mathrm{b})}} \\
(\mu \mathrm{g} / \mathrm{s} \text { creat })\end{array}$ & $\begin{array}{c}{[\mathrm{AM}](\mathrm{c})} \\
(\mu \mathrm{g} / \mathrm{g} \text { creat })\end{array}$ \\
\hline $\begin{array}{l}411 \\
421\end{array}$ & $\begin{array}{r}397 \\
141\end{array}$ & $\begin{array}{l}313 \\
28\end{array}$ & \\
\hline $\begin{array}{l}43 \mathrm{~F} \\
44 \mathrm{~F}\end{array}$ & $\begin{array}{r}178 \\
105\end{array}$ & $\begin{array}{r}20 \\
<\mathrm{LD}\end{array}$ & \\
\hline$\frac{46 \mathrm{~F}}{47 \mathrm{~F}}$ & $\begin{array}{l}152 \\
63\end{array}$ & $\begin{array}{rr}0 & 72 \\
4 & 106\end{array}$ & 60. \\
\hline $\begin{array}{l}48 F \\
497\end{array}$ & $\begin{array}{r}195 \\
192\end{array}$ & $\begin{array}{r}132 \\
200 \\
\end{array}$ & \\
\hline $\begin{array}{l}50 \mathrm{~F} \\
51 \mathrm{~F}\end{array}$ & $\begin{array}{r}604 \\
171 \\
\end{array}$ & $\frac{190}{41}$ & 178 \\
\hline $\begin{array}{l}52 \times 1 \\
581 \mathrm{~T}\end{array}$ & $\begin{array}{r}655 \\
122\end{array}$ & $\begin{array}{r}196 \\
27 \\
\end{array}$ & \\
\hline $\begin{array}{l}55 \mathrm{NT} \\
5 \mathrm{NUT}\end{array}$ & 341 & $\begin{array}{r}276 \\
-93 \\
\end{array}$ & $\begin{array}{r}<\mathrm{LD} \\
28\end{array}$ \\
\hline $\begin{array}{l}58 \mathrm{~F} \\
62 \mathrm{VI}\end{array}$ & & $\begin{array}{l}128 \\
240\end{array}$ & $\begin{array}{l}122 \\
63\end{array}$ \\
\hline
\end{tabular}

(a) Condições: injeção $=10 \mu \mathrm{L}$; coluna Ultrasphere ODS; fase móvel $=$ MeOH/HAc, $1 \%, v / v(10: 90)$; deteçãa $=262 \mathrm{~nm}$. LD $=55 \mu \mathrm{g} / \mathrm{L}$.

(b) Injeção $=10 \mu \mathrm{L}$; coluna Ultrasphere ODS; fase móvel = MeOH $/$ HAc 1\%, com gradiente; deteç̧ão $=262 \mathrm{~nm}$. $\mathrm{LD}=23 \mu \mathrm{g} / \mathrm{L}$.

(c) Injeção $=10 \mu \mathrm{L}$; coluna Hibar ${ }^{\text {RT }}$ 250-4; fase móvel $=\mathrm{MeOH} / \mathrm{HAc} 1 \%$ $(10: 90, v / v) ;$ deteç̧ão $=262 \mathrm{~nm} . \mathrm{LD}=54 \mu \mathrm{g} / \mathrm{L}$.

$F=$ Amostras de urina de fumantes.

NF = Amostras de urina de não fumantes.

LD = Limite de deteç̧ão. 
As medidas apresentam pouca concordância e uma das causas principais está na coluna analítica, embora a eluição também tenha sido variada.

A maioria dos trabalhos descritos na literatura envolvendo a separação de AM da urina por HPLC, utiliza a coluna LiChrosorb C18, da Merck, a qual têm as seguintes características: comprimento $=250 \mathrm{~mm}$; diâmetro interno $=4,6 \mathrm{~mm} \mathrm{e}$ diâmetro de partícula $=5 \mu \mathrm{m}$ (Ducos et al., 1990; Brondeau et al., 1992; Melikian et al., 1993; Barctzak et al., 1994; Popp et al., 1994; Lauwerys et al., 1994; Grotz et al., 1995; Gobba et al., 1997; Kivistö et al., 1997). No entanto, esta coluna não esteve disponível para a realização deste trabalho. Quatro outras colunas com o mesmo tipo de fase ligada à sílica e mesmo diâmetro de partícula foram empregadas para a análise do AM urinário.

É sabido, porém, que a diferença entre colunas cromatográficas não se limita às dimensões das partículas e ao tipo de fase ligada. Outros fatores importantes precisam ser levados em consideração, tais como, uniformidade dos tamanhos das partículas, tamanho de poro, área de superfície, pureza da sílica, reação utilizada para ligar a fase apolar à sílica, modo de enchimento e a porcentagem de carbono representando a quantidade de fase quimicamente ligada. Todas estas variáveis determinam as características do material de recheio, que por sua vez determinam a capacidade da coluna e influenciam na resolução da separação de misturas (Collins \& Braga, 1987).

As colunas avaliadas neste trabalho não proporcionaram uma boa separação do AM permitindo formas de picos diferentes. Devido ao fato do pico do AM às vezes aparecer na cauda de um pico maior, fez com que nem sempre a integração da área pudesse ocorrer na linha de base do cromatograma. Assim, resultados diferentes podem ser obtidos para uma mesma amostra, se esta for analisada em condições diferentes.

Outra causa de discordância de resultados pode ser uma eventual degradação da amostra. As análises foram realizadas em épocas diferentes e apesar das amostras estarem mantidas à $-20^{\circ} \mathrm{C}$, temperatura supostamente adequada para garantir a estabilidade, pode ter havido degradação das mesmas. 
Também foi observado que a separação do AM extraído de amostras de urina piorou à medida em que o número de determinações aumentou, provavelmente devido à compostos da urina que permaneceram retidos na coluna. Isto certamente comprometeu a eficiência das colunas utilizadas.

A utilização de eluição por gradiente linear de fase móvel como procedimento para a diminuição do tempo de análise e maior eficiência na limpeza da coluna, só foi possível com a coluna Ultrasphere ODS. As eluições por gradiente com a coluna Hibar ${ }^{\circledR}$ RT 250-4 apresentaram uma linha de base instável e assim foi utilizado o modo isocrático nas análises com esta coluna.

As tentativas para estabelecer uma condição analítica ótima para a separaçāo do AM por HPLC limitaram-se aos testes de colunas e variações nas proporções dos componentes da fase móvel. A maioria dos trabalhos descritos na literatura envolvendo a separação do AM urinário por HPLC utiliza condições analíticas semelhantes, porém alguns apresentaram tipos diferentes de fase móvel. Por exemplo, a solução de ácido acético como fase móvel foi substituída por tampão fosfato (Schad et al., 1992; Lee et al., 1993; Weaver et al., 1996). Um outro tipo de fase móvel utilizado foi a mistura de ácido fórmico, tetrahidrofurano e água na proporção de 14:17:969,v/v (Buratti et al., 1996). Neste trabalho, seria necessário outras investigações relativas à composição da fase móvel para melhorar a separação do AM e consequentemente a sua quantificação.

Ainda, outras condições para a extração do AM da amostra de urina poderiam melhorar os resultados. Dos trabalhos apresentados na literatura para a separação de AM urinário, a maioria emprega cartuchos com SAX para a extração do $\mathrm{AM}$, no entanto, há divergências nos procedimentos de eluição. Foi avaliado que a lavagem dos cartuchos contendo a amostra com $12 \mathrm{~mL}$ de ácido acético 1\%, v/v, era melhor do que apenas $3 \mathrm{~mL}$ (Maestri et al.,1995). Também foi avaliado que a extração do AM com dois cartuchos com SAX em série permitiu uma melhor limpeza da amostra de urina (Popp et al., 1994). Algumas destas condições poderiam ter sido aplicadas neste trabalho com bons resultados, porém não houve tempo hábil.

A utilização de duas colunas analíticas diferentes em série e uma chave comutadora entre elas (column-switching) para a eluição da amostra é uma alternativa 
usada para diminuir interferências na separação do AM (Maestri et al., 1995). Também, a utilização de detector UV-visível equipado com dispositivo para registrar o espectro das espécies eluídas da coluna à uma certa faixa de comprimento de onda (diode-array) é uma boa técnica para o monitoramento da pureza dos componentes que estão sendo eluídos (Bartczak et al., 1994).

\section{4 - DFSFNVOI.VIMFNTO DF MFTODOT OGIA PARA A DFTFRMTNAC.ÃO DF.} AM EM AMOSTRAS DE URINA HUMANA POR CF,

Como a urina é uma matriz muito complexa, a escolha de uma condição ótima de separação do AM exige um estudo criterioso de todos os parâmetros envolvidos na análise. Por outro lado, um método analítico para a determinação de AM em urina humana necessita de sensibilidade suficiente para a deteç̧ão do AM em concentrações inferiores a $50 \mu \mathrm{g} / \mathrm{L}$. A literatura apresenta valores para a concentração média de $\mathrm{AM}$ encontrada na urina de indivíduos não fumantes e não expostos ao benzeno, em torno de $50 \mu \mathrm{g} / \mathrm{g}$ de creatinina, aproximadamente $50 \mu \mathrm{g} / \mathrm{L}$ de urina (Ghittori et al., 1995b). De um modo geral, as metodologias apresentadas na literatura para a determinação de AM urinário utilizam a cromatografia líquida ou gasosa e apenas uma não exige a etapa de extração do AM da urina (Inoue et al., 1989a).

Pelo fato do $\mathrm{AM}$ na forma iônica ser um ânion orgânico de baixa massa molar com duas cargas negativas e possuir duas duplas ligações conjugadas entre os átomos de carbono, possui características favoráveis para ser analisado por CE-UV.

\section{1 - Determinação de AM urinário sem utilização de modificador orgânico}

Primeiramente foram avaliadas as condições para a determinação do AM por CE sem o emprego de modificador orgânico no eletrólito.

\subsection{1- Avaliação das condições analíticas}

Os parâmetros analíticos avaliados foram: capilar, concentração do tampão no eletrólito, voltagem aplicada para a migração da amostra, temperatura do compartimento do capilar e modo de introdução da amostra. 


\subsubsection{1 - Capilar}

Utilizando o capilar em " $\mathrm{z}$ " foi possível a detecção do AM em uma solução padrão com concentração de 0,5 $\mu \mathrm{g} / \mathrm{L}$. Desta maneira este capilar foi escolhido para as determinações de AM nas amostras de urina.

\subsubsection{2 - Tampão}

O tampão em CE tem a função das fases estacionária e móvel em cromatografia. Por isso é de fundamental importância a escolha de um tampāo adequado nas análises por $\mathrm{CE}$, pois a velocidade de migração do soluto, eficiência da separação e forma do pico são sensíveis às características do tampão. A capacidade de tamponamento é outro fator importante a ser considerado na escolha de um tampão (Janini \& Issaq, 1993).

O eletrólito composto por tampão fosfato de sódio $\mathrm{pH} 7,0$ mostrou ser adequado para a separação do AM em amostra de urina por CE-UV. Este tampão foi avaliado à diversas concentraçōes com o objetivo de melhorar a separação do AM. Foi constatado que o aumento da concentração do tampão no eletrólito provoca um aumento na eficiência da análise (os picos afinam) e uma diminuição do tempo de migração. No entanto, a concentração acima de $60 \mathrm{mmol} / \mathrm{L}$ provoca a co-migração do AM e de outros compostos da urina e a alta corrente gerada ocasiona interrupções na migração da amostra. Assim, a melhor condição para a separação do AM da urina foi obtida com o tampão fosfato de sódio $\mathrm{pH} 7,0$ a $60 \mathrm{mmol} / \mathrm{L}$.

Os grupos silanoatos da parede do capilar, negativamente carregados, atraem os cátions do tampão e formam uma camada elétrica interna fixa. No entanto, a densidade de carga destes cátions não é suficiente para neutralizar toda a carga negativa da parede do capilar e assim, uma outra camada elétrica móvel, mais externa, é formada com os cátions do tampão. Estas duas camadas de cátions formam a chamada dupla camada elétrica.

A concentração do tampão é inversamente proporcional à espessura da dupla camada elétrica. O aumento na concentração do tampão provoca uma diminuição na espessura desta camada, que por sua vez diminui o potencial zeta $(\zeta)$ e consequentemente o fluxo eletroosmótico. Por outro lado, este aumento na 
concentração do tampão provoca um aumento da força iônica gerando maior corrente elétrica. Pelo efeito Toule, este fato acarreta em aumento da temperatura no interior do capilar. Este aumento de temperatura diminui a viscosidade do tampão, aumentando o fluxo eletroosmótico (Baker, 1995). Como neste trabalho foi observado que o aumento da concentração do tampão provocou um aumento da corrente elétrica e uma diminuição no tempo de migração, pode ser concluído que o segundo efeito foi mais pronunciado do que o primeiro nas condições utilizadas.

\subsubsection{3 - Voltagem}

A voltagem em CE é diretamente proporcional ao fluxo eletroosmótico. Aumentando a voltagem aplicada, em módulo, para realizar a migração foi observado que o tempo de migração das espécies diminuiu e os picos no eletroferograma ficaram mais finos e melhor separados. Com o emprego de voltagens de até $-25 \mathrm{kV}$ não foram obtidas separações satisfatórias entre o AM e outros componentes da urina. Os melhores resultados foram obtidos com $-30 \mathrm{kV}$, que é a maior diferença de potencial permitida pelo equipamento. Nesta condição, entretanto, a corrente gerada durante a migração da amostra atingiu o valor de 308 $\mu \mathrm{A}$. A alta corrente aumentou a temperatura no interior do capilar (efeito Joule) proporcionando uma condição de migração pouco estável.

\subsubsection{4 - Temperatura}

Em análises por eletroforese capilar, mudanças na temperatura do capilar durante a migração podem causar variações na eficiência, tempo de migração, volumes de injeção e resposta do detector (Baker, 1995). Isto faz com que o controle de temperatura seja um fator de extrema importância neste tipo de análise. Há muitas maneiras para manter a temperatura do capilar constante durante a migração eletroforética. $O$ equipamento de eletroforese utilizado neste trabalho mantém a estabilização da temperatura através de uma ventilação forçada, enviando o calor externo para dentro do compartimento do capilar. Este não é um processo eficiente para a estabilização da temperatura do capilar. Equipamentos com este tipo de resfriamento do capilar necessitam ser mantidos em salas com ar condicionado e temperatura ambiente controlada (Shirao et al., 1994). 
$\mathrm{O}$ aumento da temperatura do forno do equipamento durante as análises provocou uma diminuição no tempo de migração e na resolução do pico do AM devido ao aumento na viscosidade do tampão. As separaçōes realizadas à $30^{\circ} \mathrm{C}$ apresentaram um número maior de picos no eletroferograma provavelmente decorrente da degradação da matriz urina e ao aumento na eficiência da separação. No entanto, a estabilização do equipamento à $20{ }^{\circ} \mathrm{C}$, principalmente no verão, é difícil, pois o forno resfria com a temperatura externa, a qual deve estar cerca de $5^{\circ} \mathrm{C}$ abaixo da temperatura do compartimento do capilar. Desta forma, a temperatura à $25^{\circ} \mathrm{C}$ se mostrou mais adequada para a realização das análises.

\subsubsection{5 - Introdução da amostra}

Em qualquer tipo de análise química é de importância fundamental que haja um perfeito controle do volume analisado para que uma boa reprodutibilidade dos resultados seja obtida. Em eletroforese capilar, em particular, esta preocupação é redobrada, pois os sistemas de injeção da amostra dependem de muitas variáveis. $\mathrm{O}$ equipamento de eletroforese capilar utilizado neste estudo possibilita que a introdução da amostra no capilar seja feita de duas maneiras distintas: aplicando uma pressão negativa na saída do capilar por um tempo determinado - injeção por pressão ou pneumática - ou aplicando uma diferença de potencial nas extremidades do capilar por um tempo determinado - injeção por voltagem ou eletrocinética. $O$ primeiro modo de injeção é influenciado, entre outros, pelo sistema de pressão do equipamento, viscosidade do tampão e temperatura do capilar, enquanto que o segundo depende da mobilidade eletroosmótica e eletroforética, viscosidade do tampão e temperatura (Baker, 1995).

Os dois sistemas de injeção foram avaliados neste trabalho (Coutrim et al., 1997b). Pelo fato de se tratar de um ânion, a voltagem utilizada nas injeções com o modo eletrocinético foi sempre negativa com o anodo localizado na saída do capilar. As injeçōes no modo pneumático foram realizadas com uma pressão igual a 5 pol de Hg. Embora o equipamento possibilite a utilização de dois valores de pressão, 5 e 20 pol $\mathrm{Hg}$ apenas a pressão de 5 pol $\mathrm{Hg}$ possui uma pré-calibração podendo ser utilizada para injeções. 
Comparando os resultados dos dois sistemas de injeção observa-se que a introdução da amostra no capilar pelo método eletrocinético provocou um aumento de cerca de 5 vezes no sinal do AM em relação a injeção por pressão (Tabela XII). Embora a injeção por pressão introduza um volume muito maior de solução de AM no capilar, a área do pico do AM é maior quando a amostra é introduzida por injeção eletrocinética. Isto mostra claramente que no modo eletrocinético ocorre uma pré-concentração do ânion durante a injeção havendo um aumento de sensibilidade para a deteç̧ão do AM. No entanto, através da estimativa do desvio padrão das médias das áreas dos picos do AM de 10 injeções realizadas em cada modo foi constatado que a introdução da amostra por pressão apresentou melhor repetibilidade (Tabela $X I I)$.

\section{TABELA XII - Comparação entre os modos de injeção nas análises de soluções padrões de $A M$ por $C E$ (a)}

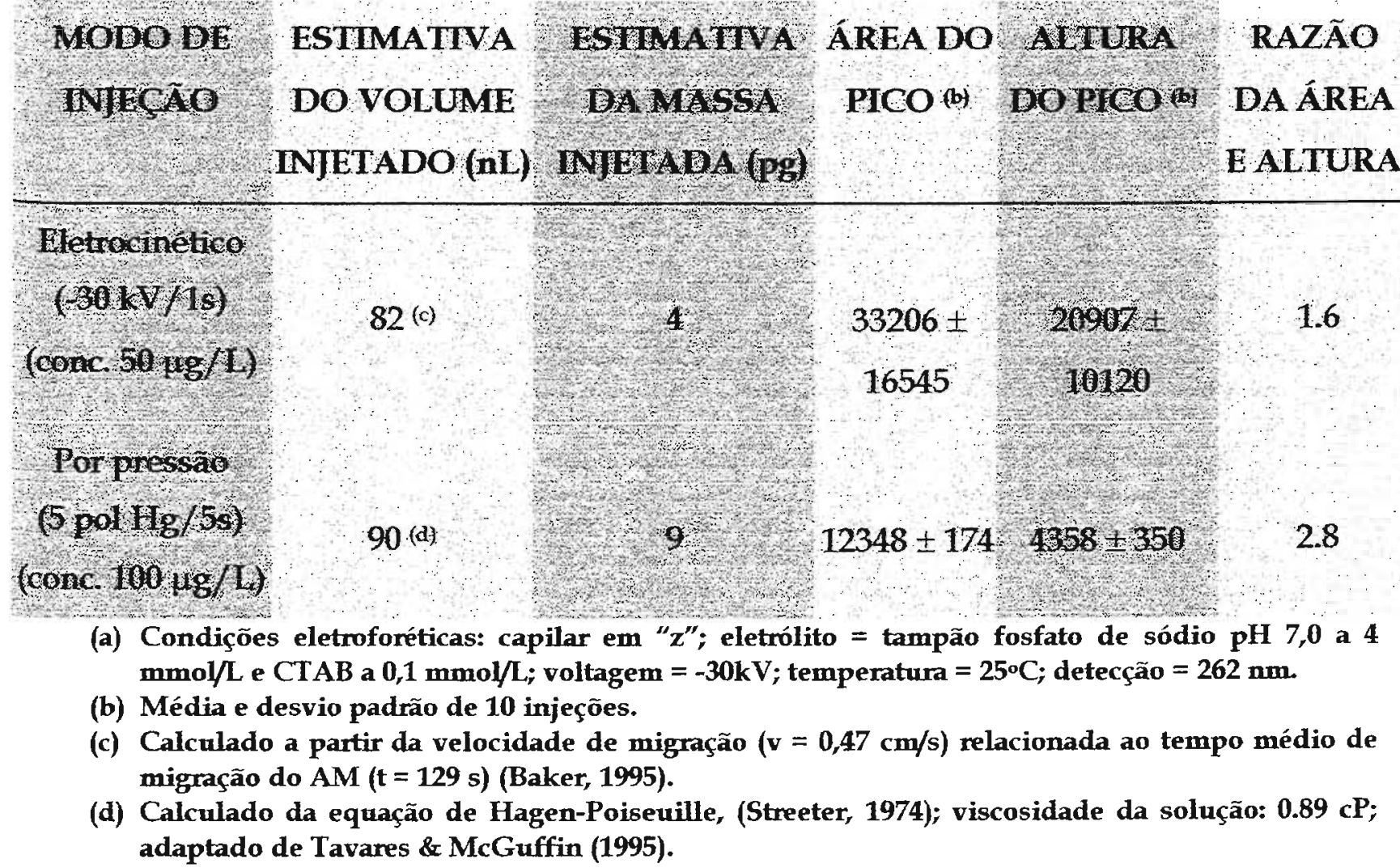

Os resultados mostram um comprometimento entre repetibilidade $\mathrm{e}$ sensibilidade. Entretanto, os limites de deteç̧ão obtidos das curvas analíticas 
construídas a partir de soluções padrões de AM, introduzidas no capilar pelos dois métodos de injeção, são muito próximos (Tabela XIII). Desta maneira, a melhor linearidade da curva analítica obtida com a injeção por pressão compensa a menor sensibilidade.

TABELA XIII - Comparação entre os modos de injeção eletrocinético e por pressão para a análise de ácido mucônico em soluções padrões por $\mathrm{CE}$

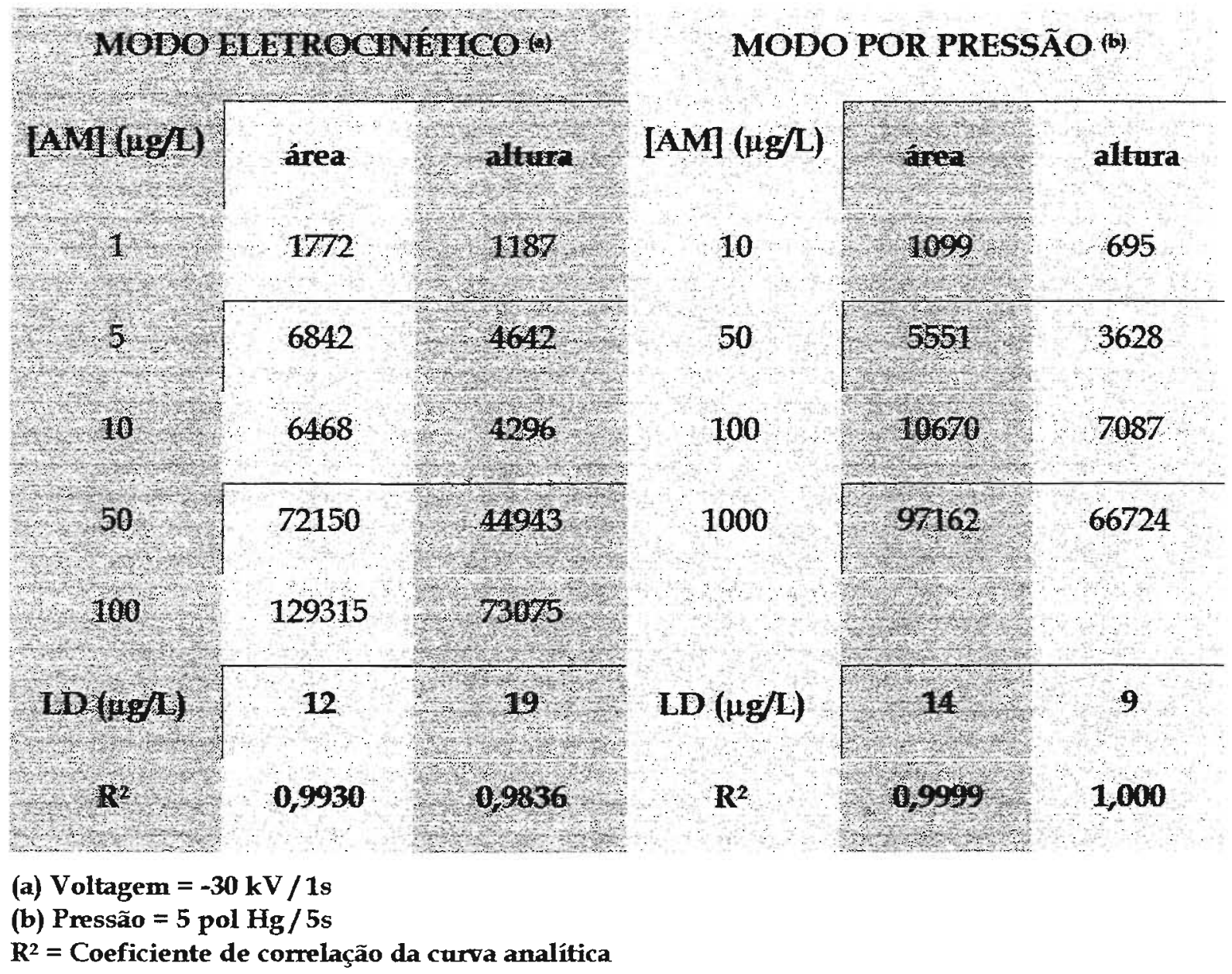

Com relação à injeção da amostra por pressão, foi feito um estudo comparativo da resposta do detector para análise de soluções padrões em diferentes concentrações e de uma mesma solução padrão injetada em diferentes tempos no capilar. O objetivo do estudo foi avaliar a possibilidade de substituir a injeção de várias soluções padrões para a construção da curva analítica, por uma única solução padrão introduzida no capilar em diferentes tempos. Esperava-se, por exemplo, que 
a área ou altura do pico do AM na solução padrão de $100 \mu \mathrm{g} / \mathrm{L}$ injetado durante 2 segundos fosse igual a área ou altura do pico do AM na solução de $200 \mu \mathrm{g} / \mathrm{L}$ injetado durante 1 segundo com a mesma pressão. Assim, foram comparadas as áreas e as alturas médias de cinco soluçōes padrōes de AM com 100, 200, 300, 400 e $500 \mu \mathrm{g} / \mathrm{L}$ introduzidas no capilar sob uma pressão negativa de 5 pol de $\mathrm{Hg}$ aplicada durante 1 segundo, com as áreas de uma solução padrão de $100 \mu \mathrm{g} / \mathrm{L}$, introduzida no capilar durante 1, 2, 3, 4 e 5 segundos sob pressão negativa de 5 pol de $\mathrm{Hg}$. Foram feitas análises com injeções pelos dois métodos em duplicatas, em dois dias diferentes.

Os resultados representando as médias das áreas e alturas das duplicatas obtidos em 28/08/96 estão apresentados na Tabela XIV e os obtidos em 03/09/96 estão na Tabela XV.

As diferenças entre as alturas obtidas pelos dois métodos de injeção foram sempre maiores do que as diferenças entre as áreas respectivas.

TABELA XIV - Comparação do sinal de AM de soluções padrões injetadas por pressão em 28/08/96, com variações de concentração e tempo de injeção

\begin{tabular}{|c|c|c|c|c|c|c|c|}
\hline $\begin{array}{l}\text { VAR } \\
\text { CONR }\end{array}$ & $\begin{array}{l}\text { NAO } \\
\text { MIA }\end{array}$ & $\mathrm{AO}$ & $\begin{array}{r}\text { VARIAC } \\
\text { DI }\end{array}$ & $\begin{array}{l}10 \mathrm{DO} \\
\mathrm{NJECA}\end{array}$ & EMPO & $\begin{array}{r}\text { BUIER } \\
6\end{array}$ & $\mathrm{NG}_{\mathrm{SAS}}$ \\
\hline $\mathrm{N} M(1 / \mathrm{gL})$ & área & altura & Tempo (s) & Area & altura & area & altura \\
\hline 100 & 2776 & 1870 & 1 & 2862 & 2017 & 67 & $-7,9$ \\
\hline 200 & 5266 & 3807 & 2 & 5262 & 3485 & 0,076 & 8,3 \\
\hline 800 & 7526 & 5098 & 3 & 7578 & 4995 & 962 & 20 \\
\hline 400 & 11471 & 8772 & 4 & 9652 & 6338 & & 22 \\
\hline 800 & 14654 & 965 & 5 & 11801 & 7730 & , & 20 \\
\hline
\end{tabular}




\section{TABELA XV - Comparação do sinal de AM de soluções padrões injetadas por pressão em 03/09/96, com variações de concentração e tempo de injeção}

\begin{tabular}{|c|c|c|c|c|c|c|c|}
\hline $\begin{array}{l}\text { Var } \\
\text { CONC }\end{array}$ & SAR & 0 & $\begin{array}{r}\text { VARRAC } \\
\text { DI }\end{array}$ & $\begin{array}{l}\mathrm{AO} \mathrm{DO} \\
\text { INIECA }\end{array}$ & $\begin{array}{l}\mathrm{CEMPO} \\
\mathrm{j}\end{array}$ & DIPE & NGAS \\
\hline $\mathrm{NA}(1 \mathrm{~g} / \mathrm{L})$ & área & altura & Tempo ( & area. & altura & irea & altura \\
\hline 100 & 2249 & 1539 & 1 & 2299 & 1449 & $-2,2$ & 5,8 \\
\hline 200 & 4405 & 3118 & 2 & 4486 & 2799 & 18 & 10 \\
\hline 300 & 6819 & 4760 & 3 & 6652 & 4226 & 2,4 & 11 \\
\hline 400 & 8890 & 6164 & 4 & 8645 & 5516 & 28 & 11 \\
\hline-500 & 12011 & 8337 & 5 & 10742 & 6819 & 11 & 19 \\
\hline
\end{tabular}

Avaliando as diferenças apresentadas na Tabela XV entre as áreas obtidas pelos dois sistemas, é possível observar que estas estiveram sempre em torno de $\pm 2 \%$ para uma faixa de concentração entre 100 e $400 \mu \mathrm{g} / \mathrm{L}$ de $\mathrm{AM}$, comparada com os tempos entre 1 e 4 segundos. No entanto, as diferenças correspondentes apresentadas na Tabela XIV são muito maiores e, apenas as áreas relativas às concentrações iguais a 200 e $300 \mu \mathrm{g} / \mathrm{L}$ (tempos de 2 e 3 segundos) apresentaram diferenças pequenas. As diferenças entre as áreas ou alturas obtidas da comparação da concentração de $500 \mu \mathrm{g} / \mathrm{L}$ com o tempo de 5 segundos, foram sempre maiores que $10 \%$, mostrando que este tempo de injeção não mantém proporção com as concentrações correspondentes.

Assim, neste trabalho, não foram utilizadas injeções de um mesmo padrão em diferentes tempos para a construção das curvas analíticas empregadas nas avaliações quantitativas. Em um estudo semelhante, o autor também escolheu o método de injeção com tempo fixo em 5 segundos, justificando que com tempos menores aumentam os erros relacionados à introdução da amostra (Reid, 1994). 


\subsection{2 - Determinaçāo qualitativa}

Neste trabalho a determinação qualitativa do AM urinário foi realizada através da comparação do tempo de migração e fortificação das amostras com AM padrão. O AM foi completamente separado dos compostos da urina e analisado na condição otimizada. A sobreposição dos eletroferogramas das amostras de urina, com e sem adição de AM padrão, permite identificar, sem qualquer dúvida, o pico do AM. Nas Figuras 5 e 6 são apresentados eletroferogramas de urina de indivíduos não fumante (Figura 5) e fumante (Figura 6) com e sem adição de AM padrão 500 $\mu g / L$.

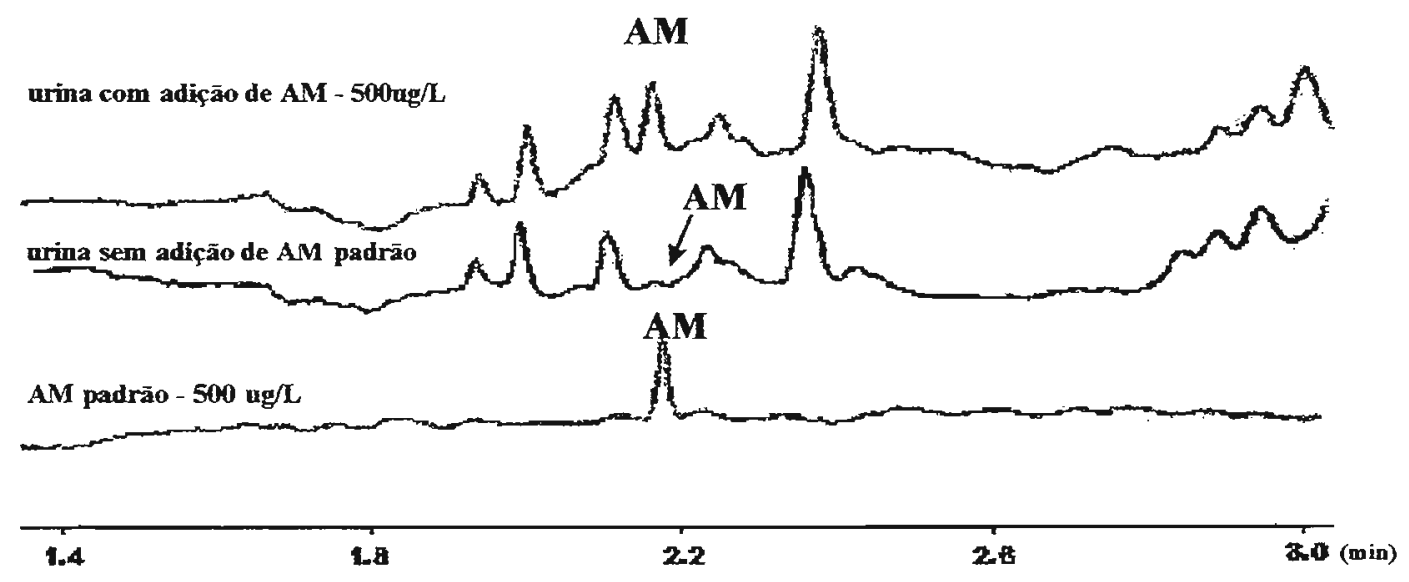

Figura 5 - Eletroferogramas de solução padrão de $A M 500 \mu g / L$ e de urina de indivíduo não fumante, com e sem adição de $500 \mu \mathrm{g} / \mathrm{L}$ de $\mathrm{AM}$, obtidos com emprego de capilar com cela ótica de alta sensibilidade e eletrólito sem metanol. 


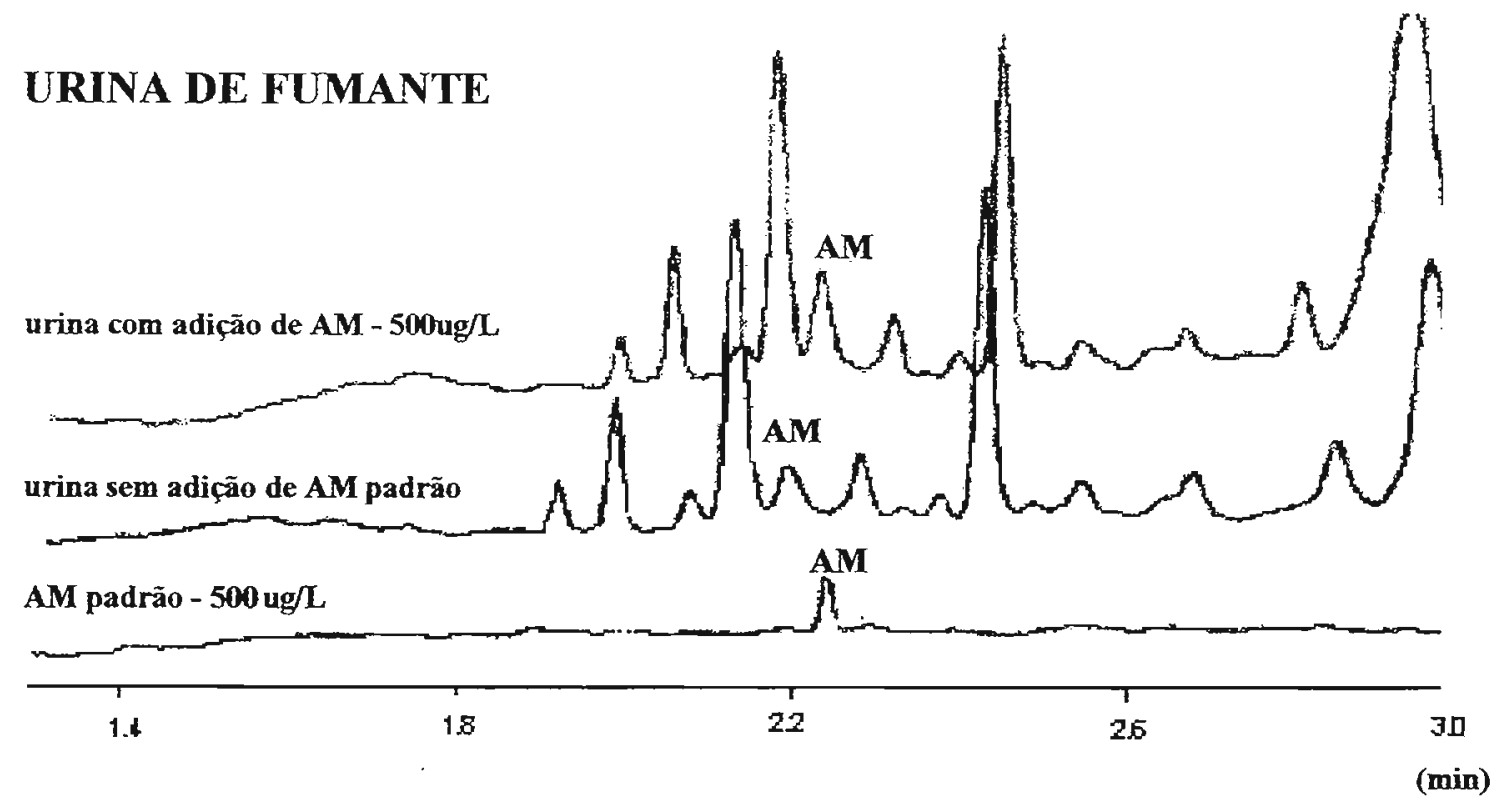

Figura 6 - Eletroferogramas de solução padrão de $\mathrm{AM} 500 \mu \mathrm{g} / \mathrm{L}$ e de urina de indivíduo fumante, com e sem adição de $500 \mu \mathrm{g} / \mathrm{L}$ de $\mathrm{AM}$, obtidos com emprego de capilar com cela ótica de alta sensibilidade e eletrólito sem metanol.

\subsection{3 - Repetibilidade}

Como as variáveis envolvidas em uma separação eletroforética são muitas, para alcançar uma boa repetibilidade das medidas por esta técnica é necessário ter um controle rígido das condições experimentais. Desta forma, a repetibilidade por CE nem sempre é igual à outras técnicas, como por exemplo, a cromatografia.

Para avaliar a repetibilidade das áreas dos picos do $\mathrm{AM}$, uma amostra de urina de indivíduo não fumante e a mesma amostra fortificada com $500 \mu \mathrm{g} / \mathrm{L}$ de AM foram avaliadas em duplicatas em três dias. Os resultados estão apresentados na tabela XVI. Houve uma discrepância grande entre as áreas obtidas na análise da amostra com padrão realizada no dia 29/10/96 que acarretou em uma estimativa do desvio padrão relativo grande (37\%). O mesmo ocorreu com as alturas obtidas da análise realizada neste dia na amostra não fortificada, sendo que neste caso a 
estimativa do desvio padrão relativo foi de $17 \%$. Os resuitados podem ser considerados bons e é difícil justificar o motivo de alguns resultados tão discrepantes.

\section{TABELA XVI - Repetibilidade do sinal de AM em amostras de urina avaliadas no mesmo dia e em dias diferentes por CE}

\begin{tabular}{|c|c|c|c|c|c|c|c|c|}
\hline & \multicolumn{4}{|c|}{ URINA SEM ADICCÃO DE AM } & \multicolumn{4}{|c|}{ URANA COM ADICAO DE AM } \\
\hline Data & Área & $\operatorname{DPR}(\%)$ & Altura & $\operatorname{DPR}(\%)$ & Área & $\operatorname{DPR}(\%)$ & Altura & DPR (\%) \\
\hline 190106 & 1013 & 72 & 759 & 6,6 & 8723 & 27 & 6973 & 0 \\
\hline & 824 & 22 & & & 9233 & 37. & 4 & 38 \\
\hline & 631 & 11 & 562 & 4,2 & 8253 & 13 & 6745 & 1,4 \\
\hline Tr & & -23 & & 21 & & 5,6 & : & 20 \\
\hline
\end{tabular}

DPR = Estimativa do desvio padrão relativo

\subsection{4 - Recuperação}

Um outro estudo foi realizado com amostras de urina fortificadas com AM, no qual foram comparados os valores de concentração de $A M$ previamente conhecidos com os valores obtidos através da análise por $\mathrm{CE}$. A este estudo foi dado o nome de recuperação do método apesar de não estar envolvida nenhuma etapa de extração na amostra. A recuperação do método foi avaliada adicionando $100 \mu \mathrm{g} / \mathrm{L}$ e $500 \mu \mathrm{g} / \mathrm{L}$ de AM em 5 amostras de urina, 3 de fumantes e 2 de não fumantes. Estas amostras foram analisadas em triplicatas e as concentrações de AM foram determinadas pelo método da calibração externa. A curva analítica foi construída a partir das médias das áreas de AM de cinco soluçōes padrōes com concentrações entre 100 e $500 \mu \mathrm{g} / \mathrm{L}$, analisadas em seis replicatas sob a mesma condição. A diferença entre a concentração de AM nas amostras de urina tal qual determinada 
por CE e aquela obtida após adição de padrão, foi avaliada. Os resultados estão apresentados na tabela XVI e mostram que as diferenças encontradas estão entre 1\% e $9 \%$ e as menores diferenças foram obtidas com as amostras fortificadas com 500 $\mu \mathrm{g} / \mathrm{L}$.

\section{TABELA XVII - Avaliação da diferença entre as concentrações de AM, calculada e determinada por $\mathrm{CE}$ pelo método da calibração externa, em amostras de urina fortificadas $\operatorname{com} \mathbf{A M}$}

\begin{tabular}{|c|c|c|c|c|c|c|}
\hline \multirow[b]{2}{*}{$\begin{array}{l}\text { Amostra } \\
\text { de urina }\end{array}$} & \multicolumn{3}{|c|}{ ADIÇÃO DE $100 \mu g /$ de AM } & \multicolumn{3}{|c|}{ ADICAO DE $500 \mathrm{Mg} / \mathrm{t}$ de AM } \\
\hline & $\begin{array}{l}{[\mathrm{AM}]^{(\mathrm{a})}} \\
(\mu \mathrm{g} / \mathrm{L})\end{array}$ & $\begin{array}{l}\left.(A M)^{b}\right) \\
(\mu g / 4)\end{array}$ & $\begin{array}{c}\text { Exatidão } \\
(\%)\end{array}$ & $\begin{array}{l}\mathrm{AM}{ }^{(a)} \\
(\mathrm{kg} / \mathrm{L})\end{array}$ & & $\begin{array}{l}\text { Rxatiabo } \\
\text { (\%) }\end{array}$ \\
\hline $6 \mathrm{~F}$ & 626 & 600 & $-4,1$ & 1026 & 1058 & 3,1 \\
\hline 9NI & 173 & 171 & $-1,2$ & 573 & 609 & 6,3 \\
\hline 16 & 202 & 185 & 8,4 & 602 & 60 & 0. \\
\hline 20 & 82 & 844 & $2 ; 8$ & 1221 & 1247 & 2,1 \\
\hline N & 139 & 126 & $-9,3$ & 539 & 524 & \\
\hline
\end{tabular}

(a) Concentração esperada de $\mathrm{AM}=[\mathrm{AM}]$ adicionado $+[\mathrm{AM}]$ (média) na amostra (em triplicata).

(b) Concentração média de AM na amostra fortificada (em triplicata).

$F$ = fumante

NF = não fumante

\subsection{5 - Determinação quantitativa}

O grande poder de separação e os baixos limites de detecção encontrados pela técnica (tem sido relatado LD menor que 3 zeptomoles $=3.10^{-21}$ moles) tem proporcionado um crescimento vertiginoso no número de publicações envolvendo CE (Guzman et al., 1993). No entanto, a maioria dos trabalhos tem enfocado apenas o aspecto analítico qualitativo. A dificuldade em controlar todas as variáveis envolvidas na separação é o principal motivo dos poucos trabalhos quantitativos. $O$ método da padronização interna tem sido preferido aos outros por ser menos sensível a erros de injeções, variações instrumentais e ambientais, e a precisão da 
razão de sinal analito/padrão interno é maior quando a área é utilizada em vez da altura. No entanto, tem havido controvérsia quanto a quantificação por padrão interno. Enquanto que a utilizaçāo de padrão está associada com sensíveis melhoras na estimativa do desvio padrão relativo em alguns trabalhos, em outros não representou qualquer alteração nos resultados (Hoyt, 1993). A normalização do sinal obtida através da divisão da área do pico pelo tempo de migração, tem sido proposta como uma metodologia alternativa para a quantificação de produtos farmacêuticos separados por CE (Altria, 1993).

Devido à complexidade da matriz utilizada, nas condições analíticas empregadas não foi possível a utilização de padrão interno. O AM separado das amostras de urina de fumantes por $\mathrm{CE}$, sem adição de solvente orgânico ao eletrólito, foi quantificado pelos métodos da calibração externa, enquanto que na urina de não fumantes foi utilizado a adição de padrão. O LD obtido através da curva analítica foi igual a $25 \mu \mathrm{g} / \mathrm{L}$ de AM por litro de urina.

Os resultados apresentados na tabela XVIII podem ser classificados em dois grupos distintos: fumantes e não fumantes. É possível afirmar com mais de $95 \%$ de certeza que as concentrações médias de AM urinário dos dois grupos são estatisticamente diferentes (Miller \& Miller, 1993). Apesar do número reduzido de amostras, os resultados mostraram ser possível diferenciar a população de indivíduos fumantes e a de não fumantes a partir do teor de AM urinário. Ainda, a partir de um estudo mais elaborado avaliando um número maior de amostras seria possivel dividir os dois grupos avaliados em subgrupos. Estes subgrupos poderiam ser formados por não fumantes que convivem com fumantes (fumantes passivos) e os que não convivem, ou por fumantes e a quantidade diária de cigarros fumados (Coutrim et al., 1997a). Um estudo semelhante ao proposto aqui, foi feito por Buratti et al. (1996), no qual os autores diferenciaram estatisticamente os diversos subgrupos avaliados. 
TABELA XVIII - Concentração de AM urinário determinado por CE,
sem adição de modificador orgânico ao eletrólito

\begin{tabular}{|c|c|c|c|}
\hline $\begin{array}{l}\text { GRINA DE } \\
\text { FUNA NTE }\end{array}$ & {$[\mathrm{AM}]^{(a)}(\mu \mathrm{g} / \mathrm{L})$} & $\begin{array}{l}\text { ORNA DENAO } \\
\text { FUMANTE }\end{array}$ & {$[\mathrm{AM}]^{(b)}(\mu \mathrm{g} / \mathrm{L})$} \\
\hline 6 & 526 & 9 & 45 \\
\hline 13 & 707 & 25 & 34 \\
\hline 15 & 219 & 26 & 93 \\
\hline 16 & 102 & 27 & 4,5 \\
\hline 18 & 173 & & \\
\hline $2 \theta$ & 721 & & \\
\hline NEDIA \pm EDP & $408 \pm 278$ & MEDPIA $\pm \mathrm{EDP}$ & $44 \pm 37$ \\
\hline
\end{tabular}

(a) quantificado pelo método da calibração externa.

(b) quantificado pelo método da adição de padrão.

EDP = Estimativa do desvio padrăo

4.2 - Determinação de AM urinário com adição de modificador orgânico ao eletrólito

Embora tenha sido possível a determinação de AM urinário por CE sem adição de solvente orgânico ao eletrólito utilizando um capilar em " $z$ ", não foi possível manter as migrações eletroforéticas sob altas correntes quando se utilizou o capilar comum $($ d.i. $=50 \mu \mathrm{m})$. A causa desta instabilidade está baseada na diferença entre os capilares utilizados. A parede mais estreita (menor diâmetro externo) do capilar em " $z$ " $\left(\phi_{\mathrm{ext}}=280 \mu \mathrm{m}\right)$ comparada com a do capilar comum $\left(\phi_{\mathrm{ext}}=350 \mu \mathrm{m}\right)$ dissipa melhor o calor gerado com o aumento da corrente elétrica. Quando a temperatura de ebulição do tampão é atingida, as bolhas de ar produzidas atuam como isolante interrompendo o circuito elétrico.

Assion, foi proposta uma outra condição para a determinação de AM em urina humana por CE-UV. 


\subsection{1 - Avaliação da adição do modificador orgânico ao eletrólito}

As condições analíticas mais estáveis foram alcançadas adicionando um modificador orgânico ao eletrólito.

A adição de modificadores orgânicos ao eletrólito alteram drasticamente as condições analíticas de um sistema em CE porque as propriedades físico-químicas do tampão, superfície interna do capilar e analito são alteradas. A viscosidade, condutividade e pH do tampão são afetados pelo solvente orgânico, assim como a constante dielétrica e o potencial zeta $(\zeta)$ da superfície interna do capilar, e a carga efetiva e pKa de ácidos fracos (Schneede et al., 1994). Estes efeitos somados podem auxiliar na resolução de problemas envolvendo a separação de analitos por $\mathrm{CE}$. $\mathrm{O}$ metanol e a acetonitrila são os solventes orgânicos mais utilizados para este propósito (Janini $\mathcal{S}$ Issaq, 1993).

Com eletrólito constituído de tampão acetato/fosfato contendo $70 \%$ de uma mistura de acetonitrila/metanol $(4: 1, \mathrm{v} / \mathrm{v})$ foi possível a separação por CE dos ácidos maleico e fumárico, dois diácidos isômeros de baixa massa molar (Schneede et al., 1994). Neste mesmo estudo, os autores afirmaram que tanto a adição de metanol quanto de acetonitrila diminuem o fluxo eletroosmótico, sendo que o metanol causa uma diminuição mais acentuada que a acetonitrila. Estes resultados foram confirmados em outro estudo no qual, além do fluxo eletroosmótico, a viscosidade da mistura também foi medida (Kenndler, 1993). Kenndler (1993) verificou que a diminuição na viscosidade da mistura com adição de acetonitrila é proporcional à sua concentraçāo, enquanto que o metanol causa um aumento na viscosidade quando sua concentração aumenta até $50 \%$ e à concentrações maiores a viscosidade é diminuída.

$\mathrm{Na}$ separação dos ácidos metil e etil-malônico por CE com o tampão

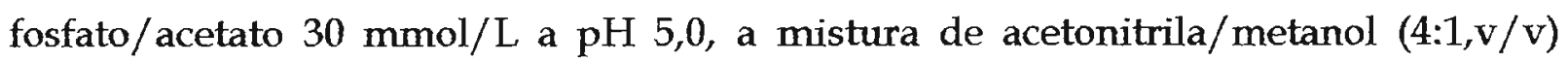
diminui a mobilidade eletroforética aparente quando adicionada ao eletrólito à concentrações inferiores a $40 \%$. Quando a faixa de concentração da mistura esteve entre $40 \%$ e $60 \%$, a mobilidade eletroforética não se alterou e em concentrações acima de $60 \%$, aumentou (Schneede et al., 1994). A separação dos diácidos isômeros metil- 
malônico e succínico em amostras de urina humana pode ser realizada por CE com adição de 30\% de acetonitrila ao eletrólito (Marsh et al., 1995).

No presente trabalho, a adição de metanol ao eletrólito diminuiu a corrente gerada durante a migração. Este procedimento permitiu a utilização de eletrólitos com tampōes mais concentrados e o CTAB à uma concentração mais elevada foi adequado para inverter o fluxo eletroosmótico. Por outro lado, o tempo de migração do AM aumentou, a seletividade diminuiu (os picos se aproximaram no eletroferograma) e a relação área/altura aumentou (os picos alargaram) piorando a separação do AM na urina.

Dentre os solventes e as concentrações avaliadas, a adição de $10 \%, \mathrm{v} / \mathrm{v}$, de metanol ao eletrólito propiciou a melhor condição de análise. Com a adição de metanol ao eletrólito foi possível introduzir as amostras no capilar por até 20 segundos. As corridas eletroforéticas só ocorreram sob voltagens iguais ou inferiores a $-20 \mathrm{kV}$, em módulo, e com tampão fosfato de sódio $\mathrm{pH} \mathrm{7,0} \mathrm{a} 120 \mathrm{mmol} / \mathrm{L}$. Esta concentração de tampão e a voltagem de $-20 \mathrm{kV}$ foram escolhidas para as determinaçōes permitindo um tempo de análise menor.

\subsection{2 - Determinação qualitativa}

Na condição otimizada, os picos de AM nos eletroferogramas de amostras de urina foram bastante simétricos e as áreas equivalentes àquelas obtidas com o capilar em " $z$ ". No entanto, a eficiência diminuiu devido ao fato do pico do AM ser mais largo na base (Coutrim et al., 1997c).

As identificações dos picos do AM foram sempre realizadas pela adição de AM padrão nas amostras de urina. Nas Figuras 7 e 8 são apresentados eletroferogramas de amostras de urina de indivíduos não fumantes e fumantes, respectivamente, analisadas com a adição de metanol ao eletrólito. É possível observar que o pico do AM é separado desde a linha de base com intensidade bem maior na urina de fumante em relação à não fumante. A diferença no ruído da linha de base entre os eletroferogramas da Figura 7 e 8 está relacionada com a atenuação dos mesmos. A pequena concentração de AM na amostra de não fumante obriga a utilização de uma atenuação menor do eletroferograma para a visualização do pico. 


\section{URINA DE NÃO - FUMANTE}

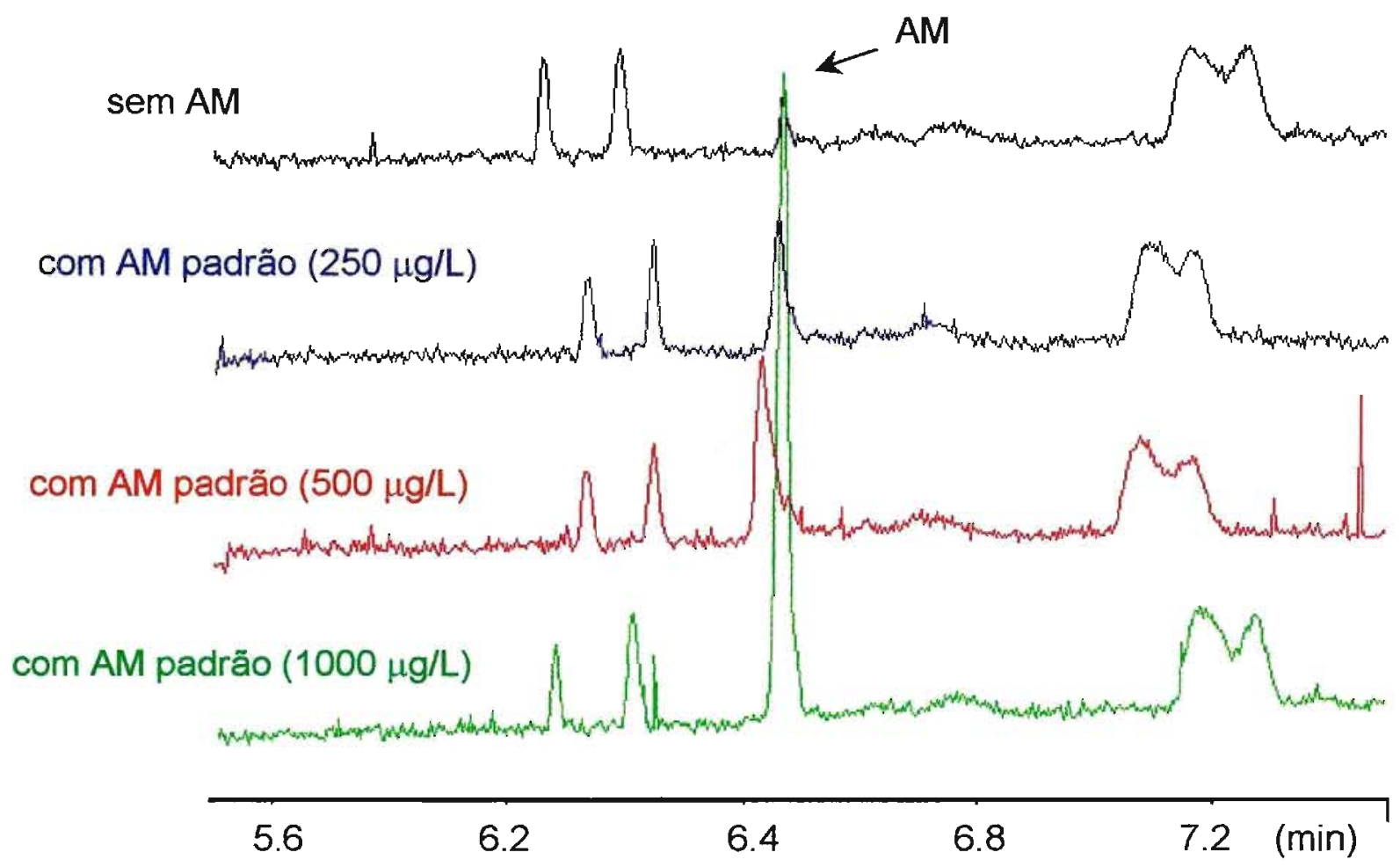

Figura 7 - Eletroferogramas de urina de indivíduo não fumante sem adição de padrão e com adição de $\mathrm{AM}$ a 250, 500 e $1000 \mu \mathrm{g} / \mathrm{L}$, obtidos com capilar de sílica comum (caminho ótico $=50 \mu \mathrm{m}$ ) e com adição de metanol ao eletrólito. 


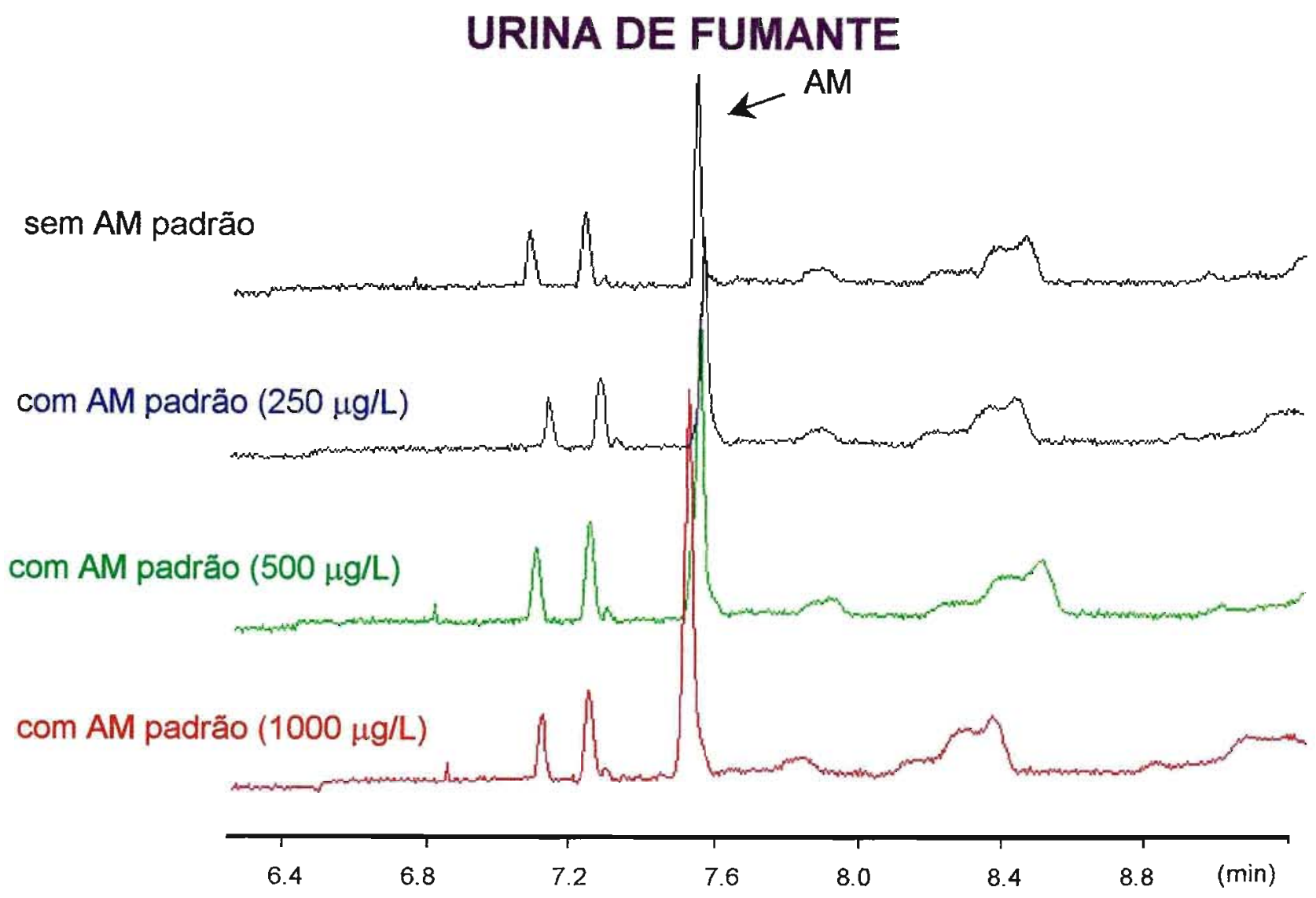

Figura 8 - Eletroferogramas de urina de indivíduo fumante sem adição de padrão e com adição de $A M$ a 250,500 e $1000 \mu g / L$, obtidos com capilar de sílica comum (caminho ótico $=50 \mu \mathrm{m}$ ) e com adição de metanol ao eletrólito.

\subsection{3 - Repetibilidade}

A repetibilidade das injeções realizadas nesta condição de análise foi avaliada através de quatro amostras de urina fortificadas previamente com $500 \mu \mathrm{g} / \mathrm{L}$ de AM. Foram avaliadas as variações ocorridas nas áreas dos picos do AM entre as análises realizadas em um mesmo dia e entre dias diferentes. Os resultados estão apresentados na tabela XIX. Para as variações ocorridas entre as determinações realizadas no mesmo dia o maior valor da estimativa do desvio padrão foi $7,3 \%$ enquanto o menor foi $0,28 \%$. As variações ocorridas em dias diferentes apresentaram 
valores de estimativa de desvio padrão entre $4,2 \%$ e $11 \%$. Os resultados podem ser considerados bons $\mathrm{e}$ as diferenças maiores observadas nas avaliações entre dias diferentes deve alertar para a necessidade de construir as curvas analíticas no mesmo dia da realização das análises quando a quantificação for feita pelo método da calibração externa, ou analisar todas as amostras com padrões adicionados no mesmo dia quando se utilizar o método da adição de padrão.

\section{TABELA XIX - Avaliação da repetibilidade das injeções de urina para a determinação de $A M$ urinário por $C E$, com modificador orgânico}

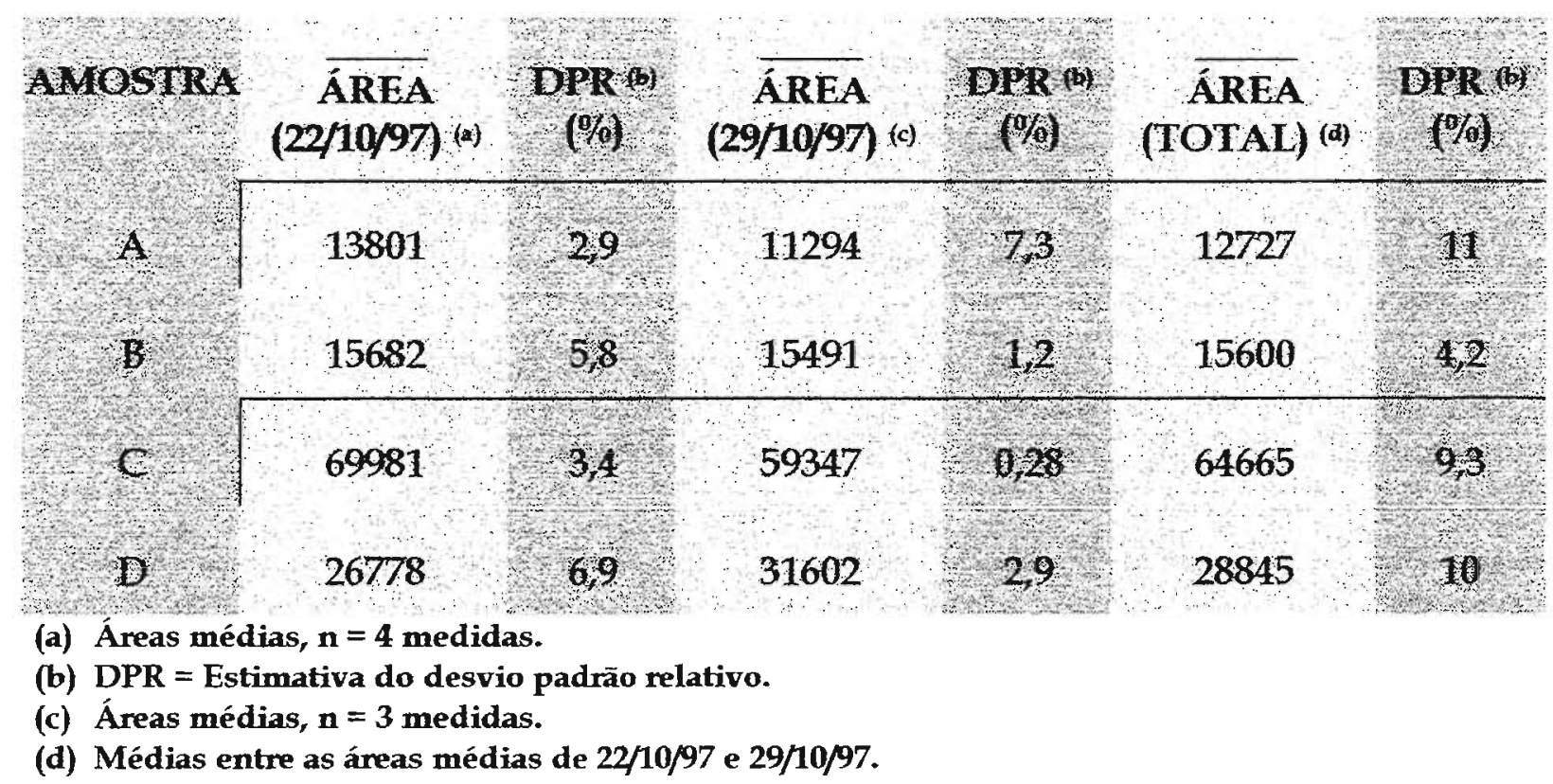

Um outro fator a ser considerado na avaliação da repetibilidade é a performance do capilar durante as análises. A literatura cita a necessidade de trocar - capilar ou recondicioná-lo à cada quinze dias durante separações de ácidos orgânicos de baixa massa molar em amostras de urina utilizando modificador orgânico (Marsh $\mathcal{E}$ Nuttall, 1995). Este cuidado não foi necessário neste trabalho, pois o mesmo capilar foi utilizado durante aproximadamente seis meses e o condicionamento foi limitado a um flush com hidróxido de sódio 0,1 mol/L durante 10 minutos entre cada série de 10 corridas. $O$ tempo de migração do AM e o perfil dos eletroferogramas não foram alterados com o tempo. 


\subsection{4 - Recuperação}

A diferenca entre as concentrações de AM na amostra de urina fortificada com o padrão e a calculada a partir da quantidade do padrão adicionado foi utilizada para avaliar a resposta do método em uma faixa de concentração de AM entre $100 \mu \mathrm{g} / \mathrm{L}$ e $3000 \mu \mathrm{g} / \mathrm{L}$. Os resultados apresentados na Tabela XX mostram que os valores de concentração de AM em urina determinados pelo método da adição de padrão são muito próximos dos valores esperados. A diferença é maior para valores menores de concentração de AM alertando para a possibilidade de haver maiores erros nas concentrações de AM na urina de não fumantes do que fumantes. As concentrações de $\mathrm{AM}$ na urina obtidas por $\mathrm{CE}$ com adição de modificador orgânico ao eletrólito não foram corrigidas com base nos resultados deste estudo, pois o mesmo foi mais qualitativo e seria necessário mais determinações para a obtenção de um fator de correção a partir deste estudo.

\section{TABELA XX - Avaliação da recuperação de AM urinário quantificado pelo método da adição de padrão (a)}

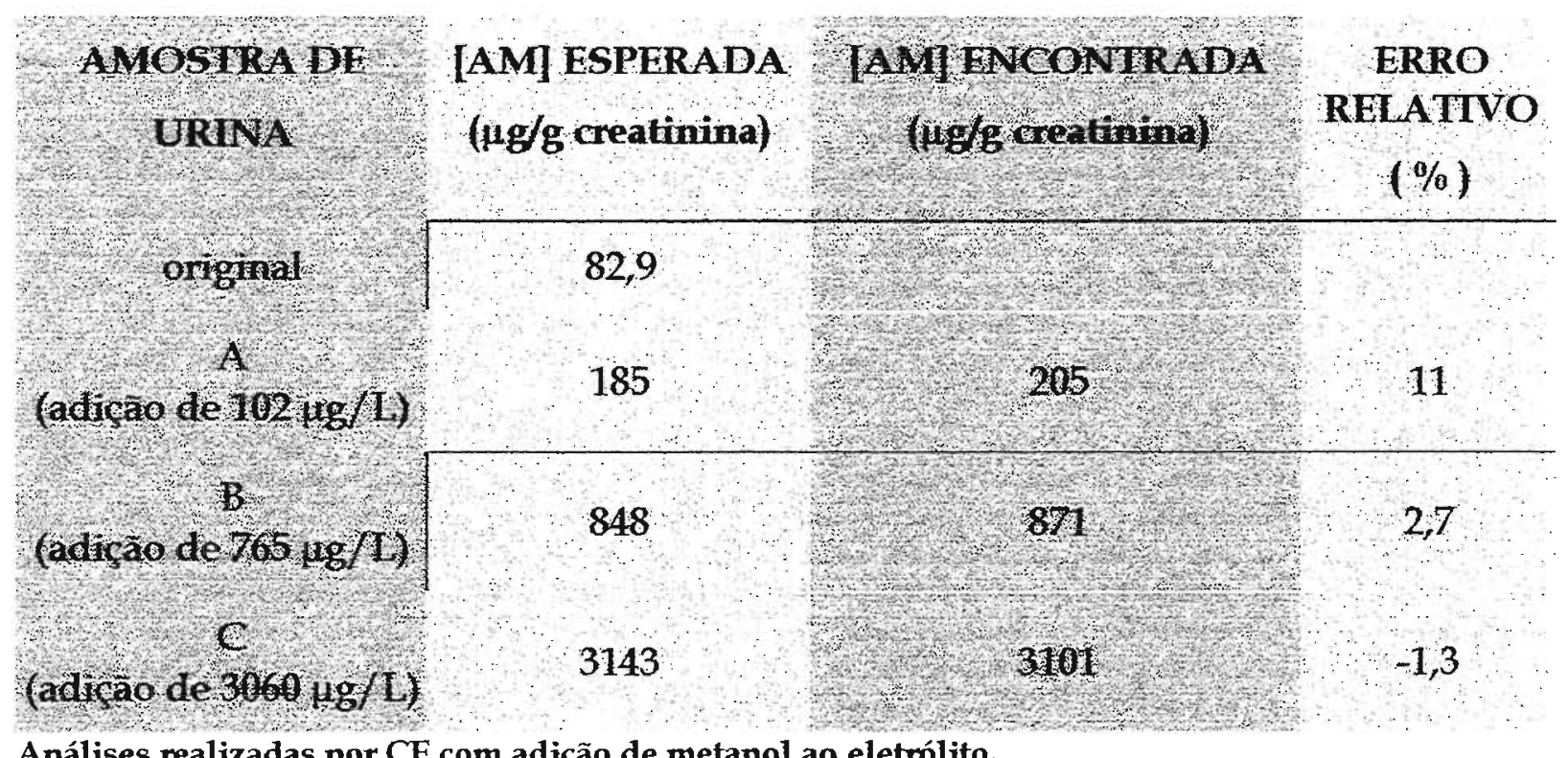

Análises realizadas por CE com adição de metanol ao eletrólito.

(a) As seguintes adições de padrão foram realizadas para a quantificação do AM: água e AM 75, 250 e $500 \mu \mathrm{g} / \mathrm{L}$ na amostra A e original; água e AM 500, 1000 e $2000 \mu \mathrm{g} / \mathrm{L}$ na amostra $\mathrm{B}$; água e AM 1000, 2000 e $5000 \mu g / L$ na amostra $C$. 


\subsection{5 - Determinação quantitativa}

As análises de amostras de urina por CE com adição de metanol ao eletrólito apresentaram concentrações de AM bem mais elevadas do que aquelas obtidas com a condição sem modificador orgânico, tanto para o grupo de fumantes quanto para o de não fumantes.

Foram analisadas 32 amostras de urina, 19 de fumantes e 13 de não fumantes. $\mathrm{O} A \mathrm{AM}$ foi quantificado nestas amostras pelos métodos da calibração externa e adição de padrão.

A quantificação pelo método da calibração externa foi realizada a partir de uma curva analítica com 5 pontos. Esta curva foi construída a partir das médias de 9 replicatas das áreas do AM obtidas de soluções padrões com concentrações entre 75 e $1000 \mu \mathrm{g} / \mathrm{L}$, analisadas sob as mesmas condições que as amostras. A curva apresentada na Figura 9 mostra o LD e o coeficiente de correlação $\left(R^{2}\right)$.

\section{CURVA ANALÍTICA PARA A QUANTIFICAÇĀO DE AM}

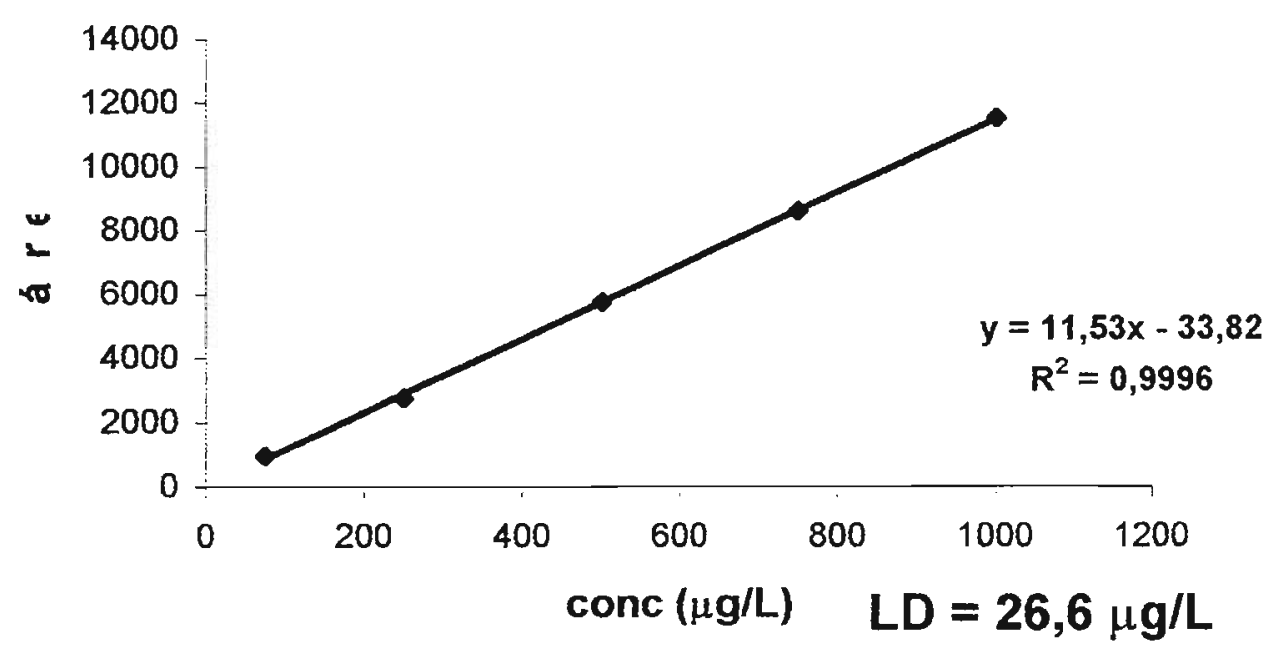

Figura 9 - Curva analítica para quantificação do AM pelo método da calibração extema ( 9 replicatas).

As amostras foram analisadas em duplicatas em dias diferentes não consecutivos. Os resultados apresentados na tabela XXI demonstram que a repetibilidade não foi boa. Alguns valores encontrados apresentam altas estimativas 
de desvio padrão, sendo um valor superior a $100 \%$, enquanto que a menor diferença observada foi igual a $4,5 \%$.

\section{TABELA XXI - AM urinário quantificado por calibração externa}

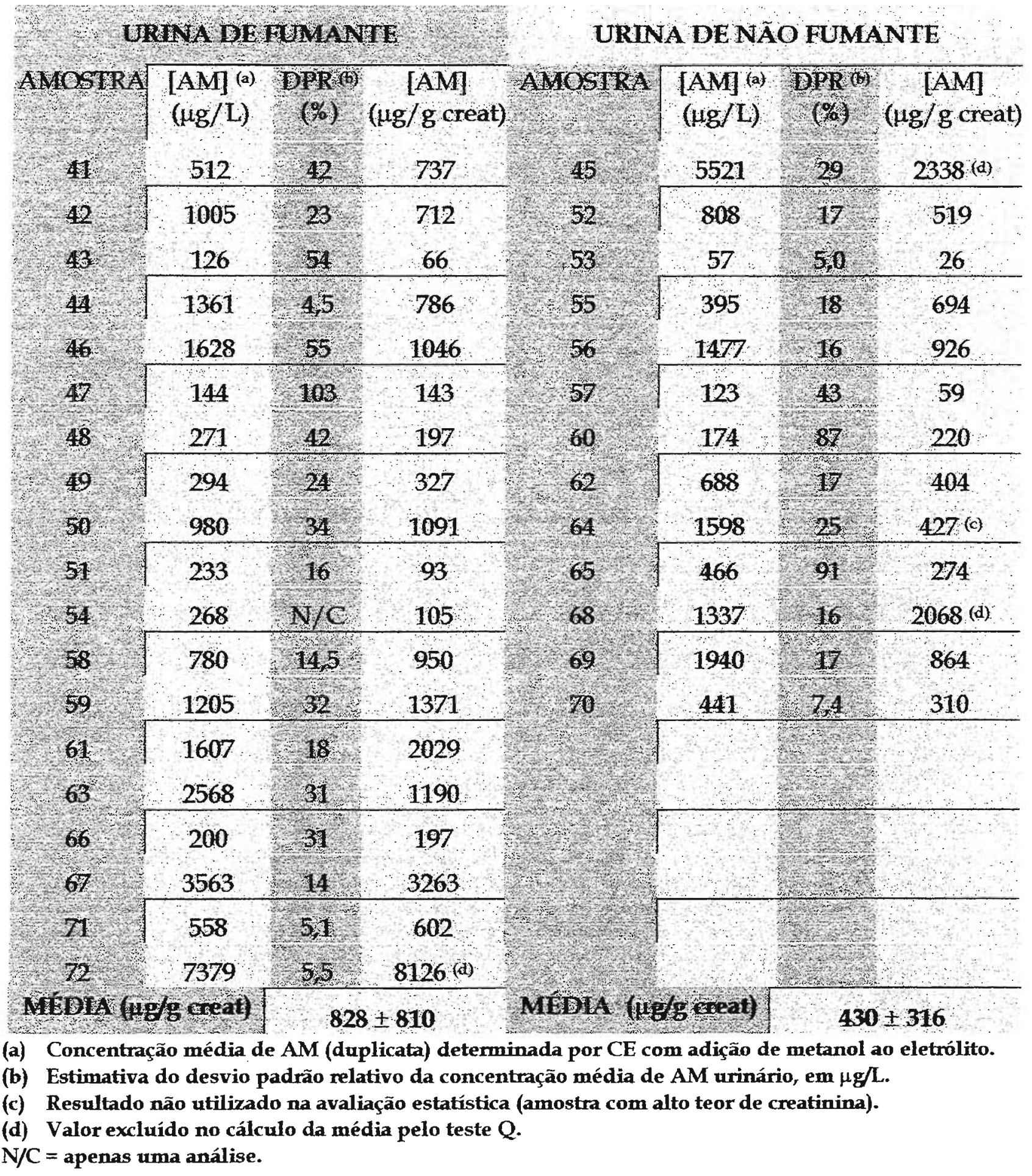


Estas diferenças podem ser atribuídas ao fato das medidas não terem sido realizadas no mesmo dia e nem em dias consecutivos e, como já é conhecida as dificuldades para a reprodução fiel das condições de análise em $C E$, a repetibilidade nas medidas não foi boa. Com o objetivo de obterem melhores resultados, o AM também foi quantificado nestas amostras pelo método da adição de padrão, o qual sofre menor interferência das variações instrumentais.

O método da adição de padrão foi utilizado através da adição de diferentes concentrações de AM padrão às amostras de urina. Um gráfico foi construído a partir da concentração do padrão adicionado contra a área do pico do AM obtida no eletroferograma da amostra de urina. A área do pico do AM na amostra sem a adição de padrão corresponde à concentração zero no gráfico. A melhor reta é traçada e a concentração que corresponde à área zero pela curva é considerada a concentração, em módulo, do AM na amostra. Na Figura 10 é apresentada uma curva analítica para a determinação da concentração de AM em uma amostra de urina pelo método da adição de padrão.

Foram feitas adições de água e AM nas concentrações de 250, 500 e 1000 $\mu \mathrm{g} / \mathrm{L}$ às amostras de urina. A adição de $\mathrm{AM}$ a $1000 \mu \mathrm{g} / \mathrm{L}$ não foi considerada no cálculo de concentração de AM das amostras com concentração de AM inferior à 500 $\mu \mathrm{g} / \mathrm{L}$ e, em 6 amostras de urina com concentração de AM superior à $1200 \mu \mathrm{g} / \mathrm{L}$ também foram feitas adiçōes de AM a $2500 \mu \mathrm{g} / \mathrm{L}$. 


\section{CURVA ANALÍTICA PARA QUANTIFICAÇÃO DE AM POR ADIÇĀO DE PADRÃO}

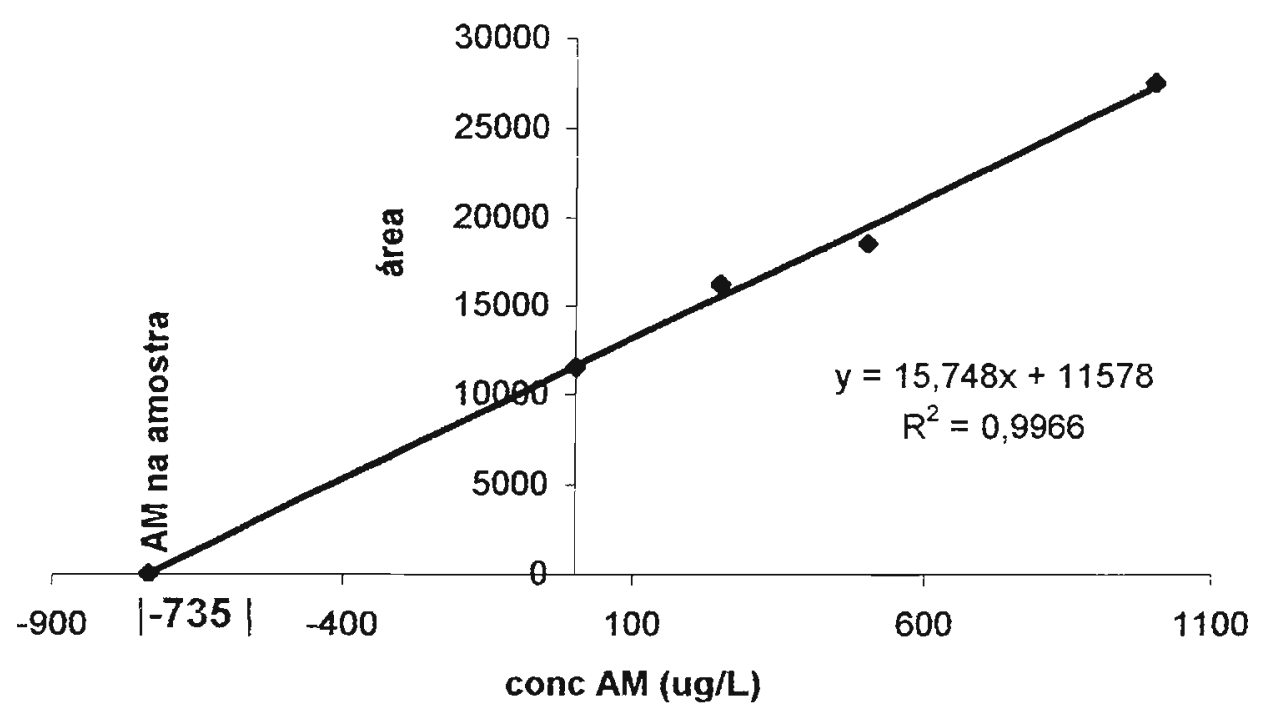

Figura 10 - Curva analítica para a determinação de AM urinário pelo método da adição de padrão (AM adicionado $=0,250,500$ e $1000 \mu \mathrm{g} / \mathrm{L}$ ).

As amostras foram determinadas em duplicata. A primeira replicata foi realizada seqüencialmente para todas as amostras $e_{r}$ só depois foi feita a segunda replicata. Devido à complexidade deste método de quantificação, o qual requer até cinco corridas eletroforéticas para a análise de uma amostra, o tempo decorrido entre a determinação de uma e outra replicata foi de quinze dias.

Os resultados (Tabela XXII) só foram considerados quando o coeficiente de correlação $\left(R^{2}\right)$ da curva analítica foi maior do que 0,9 e a concentração encontrada foi maior do que o LD, o qual representa a concentração correspondente a 3 vezes a estimativa do desvio padrão da intercepção da curva analítica. Devido à estas restrições impostas para a validação de resultados, cerca de $40 \%$ deles, obtidos em replicatas, não foram considerados. 


\section{TABELA XXII - AM urinário quantificado por adição de padrão (a)}

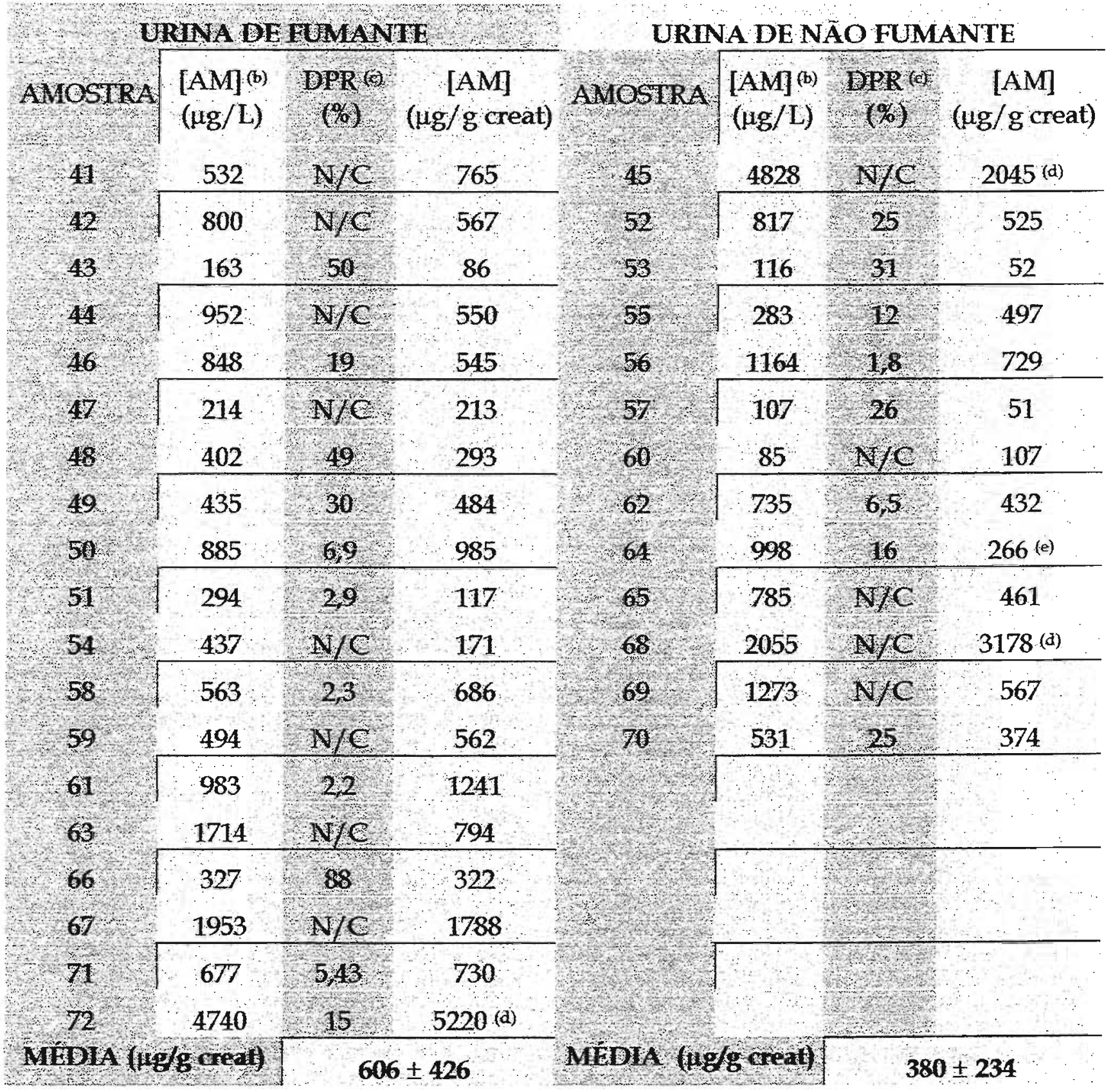

(a) Adições de soluções padrões com 250, 500, 1000 e $2500 \mu \mathrm{g} / \mathrm{L}$ de AM.

(b) Concentração de AM (média de duplicata) deteminada por CE com adição metanol ao eletrólito.

(c) Estimativa do desvio padrão relativo da concentração média de $\mathrm{AM}$ urinário, em $\mu \mathrm{g} / \mathrm{L}$.

(d) Valor excluído no cálculo da média pelo teste $Q$.

(e) Resultado não utilizado na avaliação estatística (amostra com alto teor de creatinina).

$\mathrm{N} / \mathrm{C}=$ apenas uma análise 
A maior causa de rejeição de resultados foi a falta de correlação dos pontos na curva analítica, geralmente devido a um ponto situado muito fora. Uma série de oito análises apresentou desvios nas adições de padrão que foram realizadas no mesmo dia. Este fato pode ter ocorrido devido a algum problema ocasional com o equipamento. $O$ vácuo utilizado para realizar as injeções é uma parte do equipamento muito suscetivel à problemas, pois as vedações às vezes apresentam vazamento nem sempre notado pelo operador. Se o vácuo não estiver perfeitamente ajustado mais ou menos amostra adentraram o capilar prejudicando as determinaçōes quantitativas. Outro problema que pode ter prejudicado a correlação dos pontos na curva analítica foi a dificuldade para analisar as amostras com todas as adições no mesmo dia, apesar dos esforços despendidos neste sentido. As variações nas condições analíticas ocorridas em dias diferentes podem ter interferido nos resultados.

Apesar das dificuldades para a obtenção dos resultados em duplicatas usando-se o método da adição de padrão, quando isto foi possível, as estimativas do desvio padrão foram inferiores àquelas obtidas com o método da calibração externa. Com exceção de um resultado, todas as estimativas de desvio foram inferiores a $50 \%$ sendo o menor igual a $1,8 \%$.

A comparação entre os resultados obtidos pelos dois métodos de quantificação apresentada na tabela XXIII demonstra que os mesmos não foram concordantes, no entanto, não houve tendência para um método apresentar valores sistematicamente maiores do que o outro. $O$ método da calibraçāo externa apresentou alguns resultados concordantes com o método da adição de padrão, como o da amostra 52. Também, resultados bem discrepantes foram obtidos, onde os resultados obtidos por um método de quantificação foram o dobro ou metade dos valores apresentados pelo outro método. 
TABELA XXIII - Comparação entre as concentrações de AM urinário obtidas pelos dois métodos de quantificação utilizados

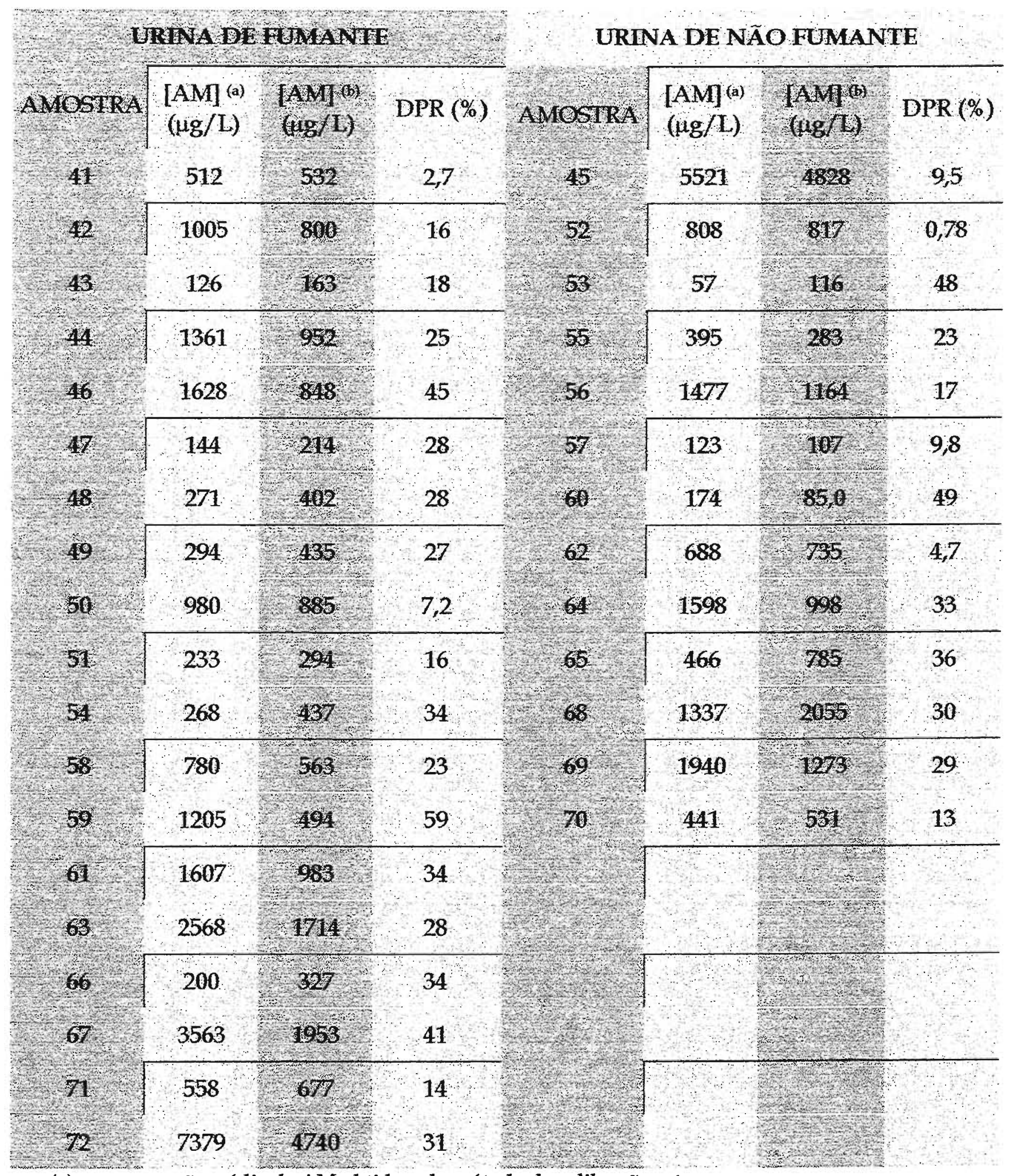

(a) concentração média de AM obtida pelo método da calibração extema

(b) concentração média de AM obtida pelo método da adição de padrão

DPR = Estimativa do desvio padrão relativo 


\subsection{6 - Avaliação das medidas de AM urinário}

Ao comparar os resultados dos dois métodos de quantificação observa-se que alguns valores de concentração média de AM encontrados em amostras de urina, tanto no grupo de fumantes quanto no de nāo fumantes, estão muito acima da média do grupo. As três amostras que apresentaram resultados mais discrepantes foram: 72 (fumante), 45 e 68 (não fumantes). O voluntário da amostra 72, indicou na resposta do questionário, que tomava diariamente 3 medicamentos e, possivelmente algum deles interferiu nas medidas de AM. A pessoa da amostra 45, embora não fumante, exercia a profissão de mecânico de ônibus e pode ter inalado algum tipo de combustível contendo benzeno apresentando amostra com alto teor de AM. No questionário respondido por este voluntário não consta qualquer comentário a respeito, no entanto, cita o convívio intenso com fumantes. Quanto à amostra 68, o voluntário pode ser considerado fumante passivo, ou seja, convive com fumante 6 horas por dia.

\section{3 - Comparação entre as concentrações de AM urinário determinados com e sem uso de metanol}

Apesar de possíveis interferências, a utilização de metanol adicionado ao eletrólito permite uma condição estável, possibilitando a injeção da amostra durante um tempo 20 vezes maior em relação à outra condição. A corrente gerada durante a migração é cerca de 4 vezes menor.

As áreas e as alturas dos picos de AM obtidas de análises de soluções padrões são apresentadas na tabela XXIV para comparação dos resultados analíticos obtidos em ambas as condições. As áreas na condição que emprega o solvente orgânico são cerca de 15\% menores em relação a outra condição, mostrando que apesar da amostra ser introduzida no capilar durante um tempo maior, a condição que utiliza o capilar em " $z$ " ainda produz um sinal maior para o pico do AM. No entanto, a menor sensibilidade não implica em diferença no LD. O LD calculado a partir das curvas analíticas, construídas com os resultados apresentados na tabela $\mathrm{XXIV}$, foi praticamente igual para as áreas, havendo uma diferença para as alturas. $\mathrm{O}$ LD em relação à área para a condição sem solvente orgânico foi $25 \mu \mathrm{g} / \mathrm{L}$ e em relação 
à altura foi $21 \mu \mathrm{g} / \mathrm{L}$, enquanto para a condição com metanol no eletrólito o LD em relação à área foi de $27 \mu \mathrm{g} / \mathrm{L}$ e à altura $59 \mu \mathrm{g} / \mathrm{L}$.

\section{TABELA XXIV - Comparação dos sinais obtidos para o ácido mucônico por eletroforese capilar em diferentes condições de análise}

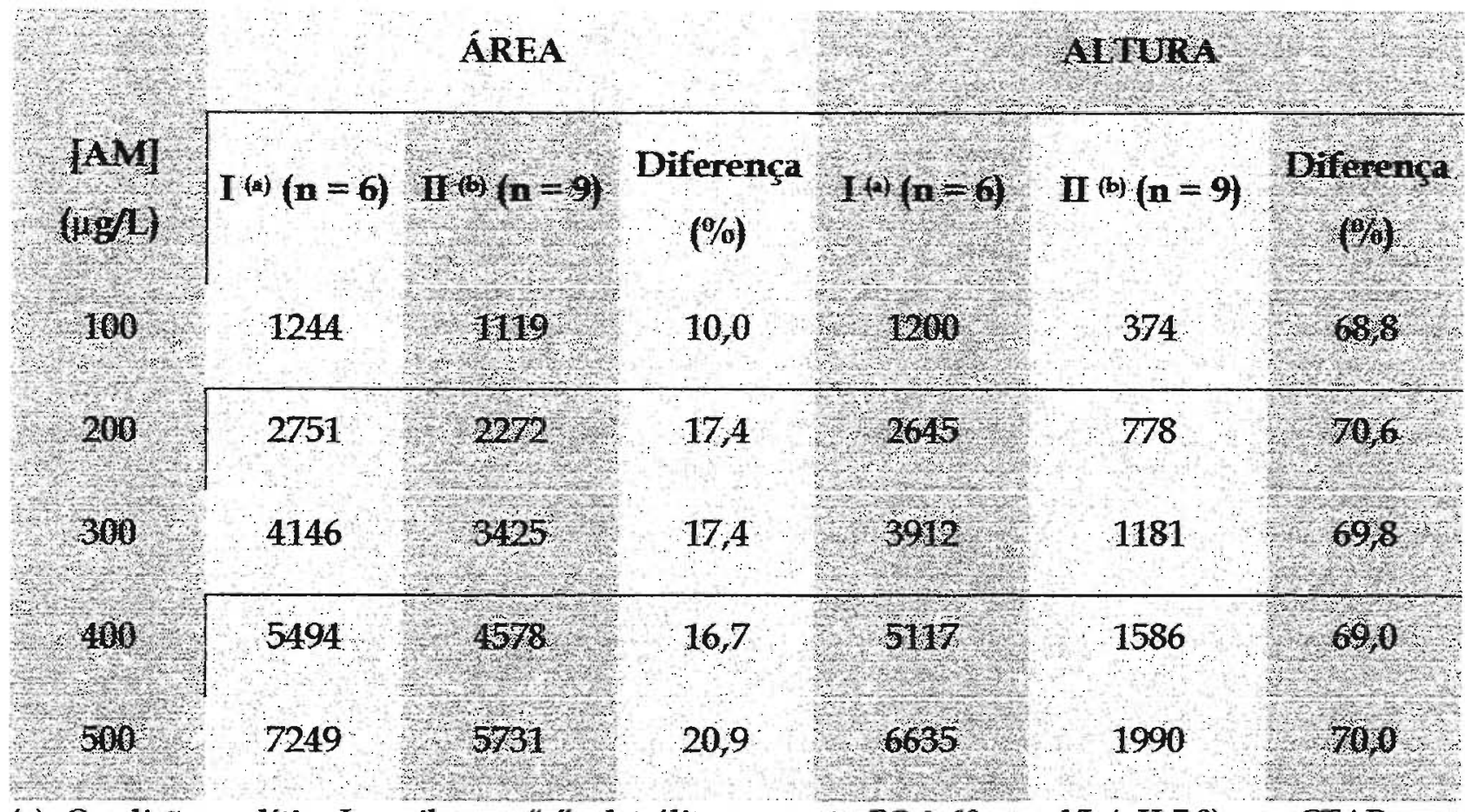

(a) Condição analítica I: capilar em "z"; eletrólito = tampão $\mathrm{PO}_{4}^{3-} 60 \mathrm{mmol} / \mathrm{L}$ (pH 7,0) com CTAB$0,1 \mathrm{mmol} / \mathrm{L}$; inj. $=5$ pol $\mathrm{Hg} / 1 \mathrm{~s}$ e migração $=-30 \mathrm{kV} / 5$ minutos.

(b) Condição analítica II: capilar comum (d.i. $=50 \mu \mathrm{m})$; eletrólito $=$ tampão $\mathrm{PO}_{4}{ }^{3} 120 \mathrm{mmol} / \mathrm{L}(\mathrm{pH}$ $7,0)+\mathrm{CTAB}-0,4 \mathrm{mmol} / \mathrm{L}$ e MeOH-10\%, v/v; inj. $=5$ pol $\mathrm{Hg} / 20$ s e migração $=-20 \mathrm{kV} / 15$ minutos.

A altura na condição com solvente orgânico foi cerca de $70 \%$ menor em relação a outra condição. Este fato, e o alargamento dos picos do AM devido ao maior tempo de retenção dentro do capilar, mostram que houve uma perda na eficiência eletroforética (picos mais largos) com a utilização de metanol.

O tempo maior de migração do $\mathrm{AM}$ na condição que emprega metanol decorre do fato que o metanol, quando adicionado ao eletrólito até uma concentração de $50 \%$ proporciona um aumento na viscosidade do tampão provocando uma diminuição no fluxo eletroosmótico (Baker, 1995). 
Ả comparação entre as duas metodologias analíticas para a separação de AM urinário deveria ser feita com a mesma amostra de urina, mas isto não foi possível devido à degradação da amostra e não disponibilidade do capilar em " $z$ ". Os resultados mostram que a concentração média de AM urinário determinada por CE pela condição que emprega adição de metanol ao eletrólito (Tabela $X X I I)$ é muito maior do que pela condição utilizando o capilar em " $z$ " (Tabela XVIII), principalmente no grupo de não fumantes. Isto pode ser explicado, em parte, porque a mobilidade eletroforética de cada íon no eletrólito é grandemente e diferentemente afetada pelo solvente orgânico, o que significa que a ordem de eluição pode ser completamente alterada (Kenndler, 1993). Neste trabalho, a adição de metanol ao eletrólito deve ter alterado a ordem de eluição dos ânions presentes na urina de maneira que na condição analítica escolhida o AM pode ter migrado com o mesmo tempo de outro(s) ânion(s).

Por outro lado, há uma grande vantagem em utilizar a condição com metanol, o custo da análise é diminuído. A diferença de preço entre os dois tipos de capilares, capilar com cela ótica de alta sensibilidade (capilar em " $\mathrm{Z}$ "; custo = $\$ 1,500.00$ por unidade) e capilar comum (custo $=\$ 15.00$ por metro) torna a análise com capilar comum mais atraente, mesmo porque os capilares são delicados e muito frágeis (Coutrim et al., 1998).

\section{5 - GRUPOS DE FUMANTES E NÃO FUMANTES DIFERENCIADOS PELO AM URINÁRIO}

As concentrações de AM corrigidas pelos teores de creatinina foram a base para classificar as amostras em dois grupos, fumantes e não fumantes. A diferença entre as médias destas concentrações quantificadas pelos dois métodos (Tabelas XXI e XXII) foram estatisticamente significativas com mais de $90 \%$ de probabilidade nos dois grupos, apesar do pequeno número de amostras analisadas (Miller $\mathcal{E}$ Miller, 1993).

Outros trabalhos semelhantes são apresentados na literatura (Melikian et al., 1993; Ong et al., 1994a; Ruppert et al., 1995; Buratti et al., 1996; Ghittori et al., 1996; 
Buratti et al., 1997; Ruppert et al., 1997). Uma comparação entre os resultados da literatura e deste trahalho está na tahela XXV. Os resultados não são concordantes entre si havendo uma variação grande entre eles. No entanto, aqueles que derivaram deste trabalho apresentam características particulares como o número de amostras menor e a concentração média de AM de fumantes significativamente maior que as apresentadas em outros trabalhos. A concentração média de AM de não fumantes obtida pelo método que utiliza a adição de metanol no eletrólito também é bem maior do que as outras (Tabela XXV).

Os fluídos biológicos oriundos de indivíduos com condições de vida semelhantes diferem muito entre si devido as diferenças no metabolismo. Esta é uma das causas da concentração média de AM urinário de não fumantes, obtida por CE sem adição de metanol ao eletrólito, ser nove vezes menor do que a obtida com adição de metanol, para o mesmo grupo. No caso de fumantes, também é observado uma concentração menor de AM. Uma outra causa de concentraçōes elevadas de AM urinário pode ser a coeluição de outros compostos presentes na urina. Esta possibilidade poderia ter sido verificada com um outro sistema de detecção ou um detector UV-visível com diode-array através do qual seria possível obter o espectro do(s) composto(s) durante um tempo de migração definido (Bartczak et al., 1994). 
TABELA XXV - Concentrações de AM na urina de fumantes e não fumantes determinadas em diversos estudos

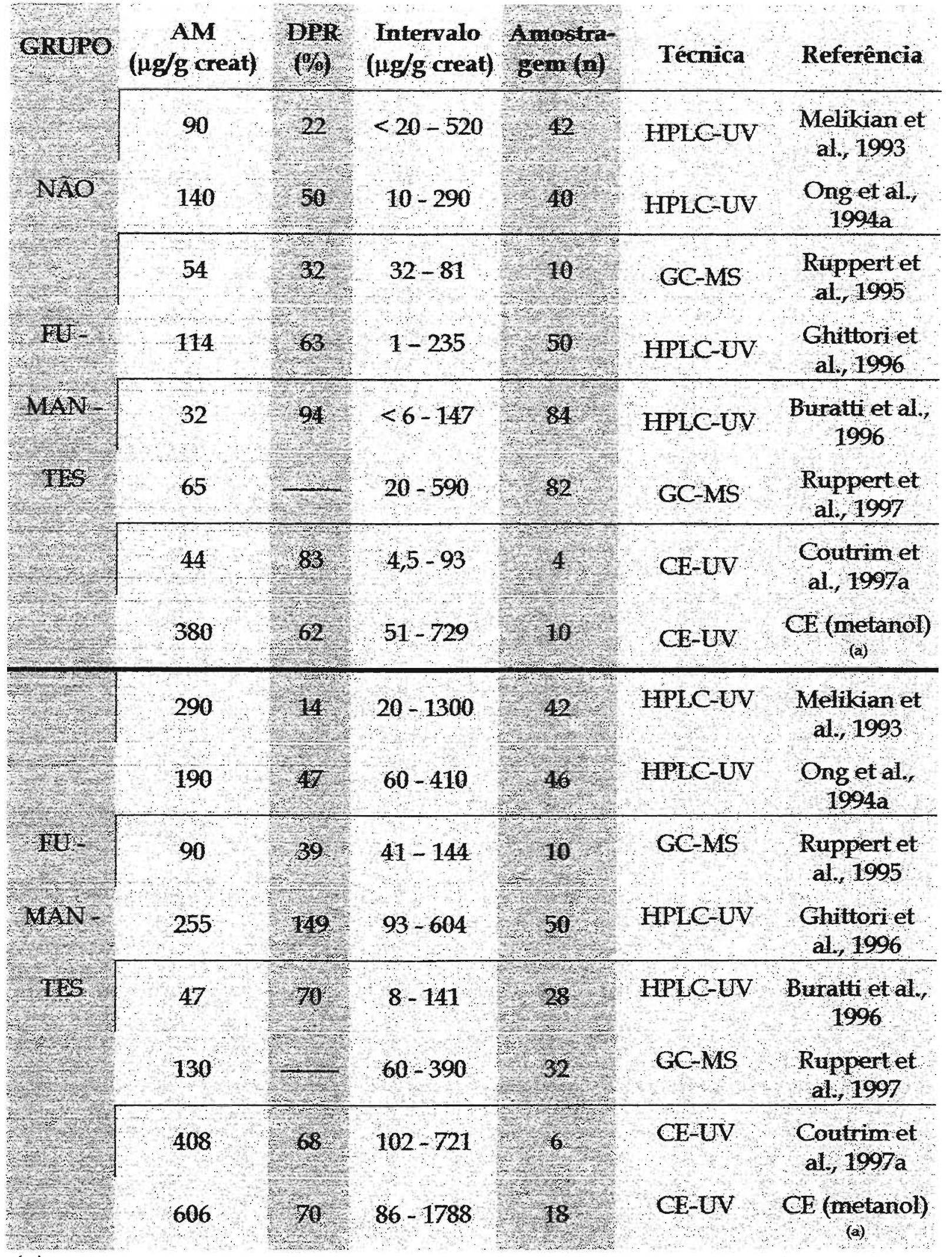

(a) Análise com adição de metanol ao eletrólito e quantificação pelo método da adição de padrão. DPR = Estimativa do desvio padrão relativo 
5.1 - Diferenciação entre não fumantes, fumantes passivos e fumantes pelo número de cigarros através do AM urinário

O AM urinário é uma determinação suficientemente sensível para distinguir estatisticamente grupos de nāo fumantes que convivem com fumantes (fumantes passivos) daqueles que não convivem (Buratti et al., 1996).

Correlaçōes entre o número de cigarros fumados e as concentrações de vários metabólitos de compostos presentes na fumaça do cigarro, inclusive o benzeno, determinados na urina de mais de 300 indivíduos, foram avaliadas e os resultados não foram estatisticamente significativos. O AM também foi avaliado neste estudo, no entanto a utilização dos resultados para comparação com outros estudos ficou prejudicada pelo fato de ter sido utilizada a mediana e não a média das concentrações encontradas (Haufroid et al., 1997).

Comparando as concentrações de AM urinário e o número de cigarros fumados diariamente, Buratti et al. (1997) obtiveram um coeficiente de correlação igual a 0,53 para 26 amostras, enquanto que o coeficiente de correlação obtido por Ghittori et al. (1996) foi igual a 0,74 para 28 amostras.

Devido ao pequeno número de amostras avaliadas, os resultados deste trabalho não apresentaram diferenças estatisticamente significativas entre não fumantes e fumantes passivos, e entre fumantes classificados pelo número de cigarros fumados.

\section{6 - COMPARAÇÃo ENTRE HPLC E CE NA DETERMINAÇÃo DE AM URINÁRIO}

As duas técnicas utilizadas para a determinação de AM urinário utilizam condições analíticas distintas, as quais apresentam vantagens e desvantagens. A técnica de CE apresenta vantagens quanto ao pré-tratamento da amostra, pois requer apenas uma simples filtração, enquanto que a metodologia por HPLC além da filtração utiliza uma extração prévia do AM. Uma corrida por CE é realizada em aproximadamente 15 minutos enquanto que por HPLC o tempo requerido é maior que 30 minutos. O volume de solvente gasto em um corrida cromatográfica é da 
ordem de mL enquanto que em CE é da ordem de $\mu \mathrm{L}$. Em HPLC é injetado $10 \mu \mathrm{L}$ de amostra e em $\mathrm{CE}$ este volume equivale a alguns nL. Por outro lado, uma vantagem da metodologia por HPLCé a maior estabilidade do sistema (Coutrim et al., 1996).

Os resultados da concentração de $\mathrm{AM}$ por $\mathrm{CE}$, quantificados pelo método da calibração externa e adição de padrão, e por HPLC, com e sem eluição por gradiente, estão apresentados na Figura 11 (fumantes) e na Figura 12 (não fumantes). De um modo geral, as concentrações obtidas por CE são maiores do que por HPLC; as amostras analisadas por $\mathrm{CE}$ e quantificadas pelo método da calibração externa apresentam concentrações de AM maiores do que aquelas obtidas por adição de padrão; por outro lado, os resultados por HPLC com eluição isocrática são maiores do que aqueles com gradiente linear.

AM NA URINA DE FUMANTES POR CE E HPLC

CE (Adição de Padrão)

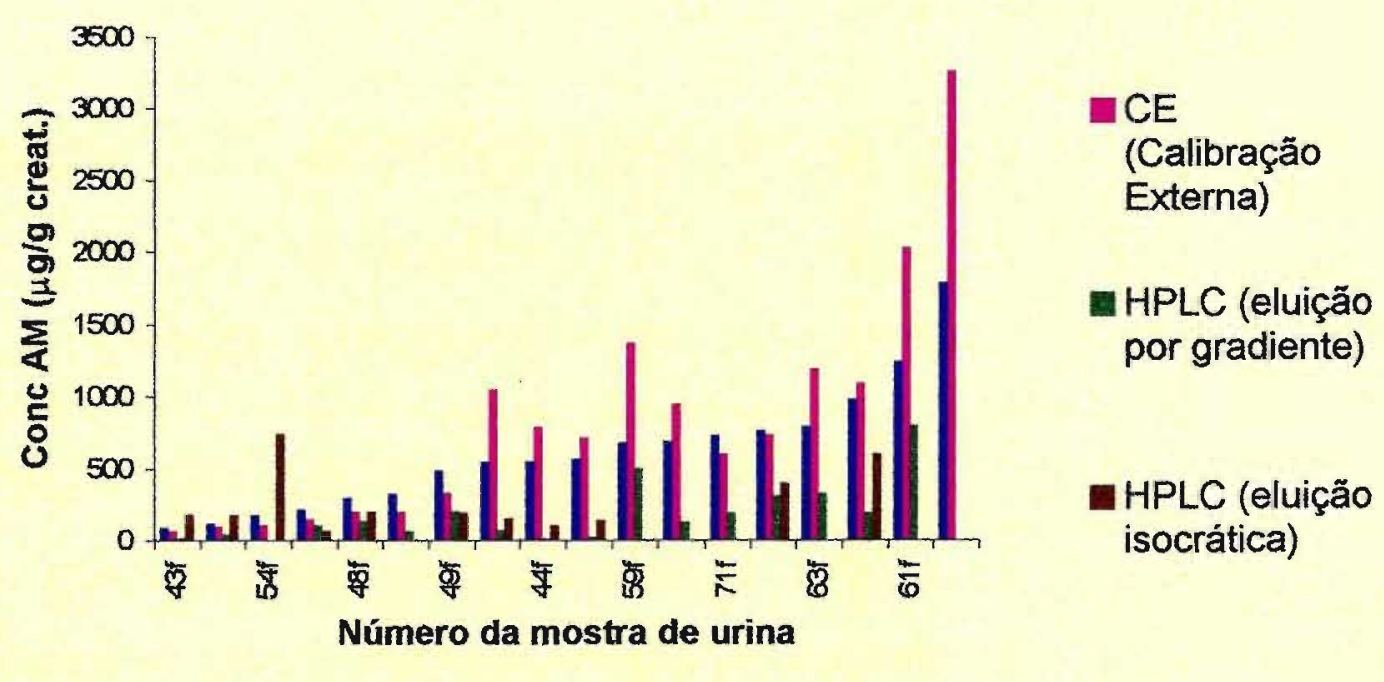

Figura 11 - Concentração de AM em urina de fumantes determinada por quatro métodos diferentes: 1) CE com metanol e quantificado por adição de padrão; 2) CE com metanol e quantificado por calibração externa; 3) HPLC com eluição por gradiente e 4) HPLC com eluição isocrática. 


\section{AM NA. URINA DE NÃO FUMANTES POR CE E HPLC}

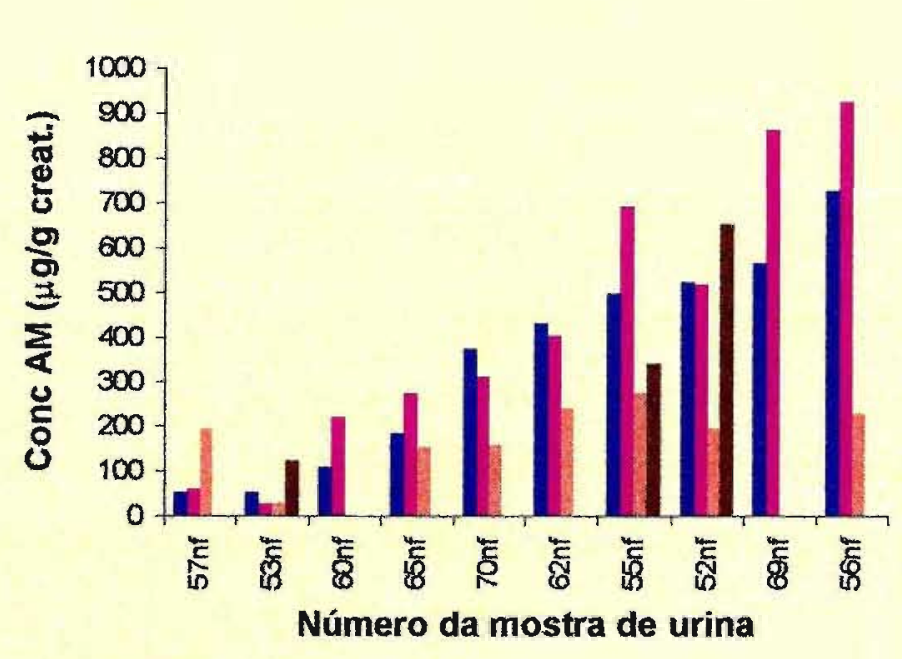

CE (Adição de Padrão)

CE (Calibração Externa)

HPLC (eluição por gradiente)

HPLC (eluição isocrática)

Figura 12 - Concentração de AM em urina de não fumantes determinada por quatro métodos diferentes: 1) CE com metanol e quantificado por adição de padrão; 2) CE com metanol e quantificado por calibração externa; 3) HPLC com eluição por gradiente e 4) HPLC com eluição isocrática.

$O$ perfil dos histogramas correspondentes à concentração de $\mathrm{AM}$ em amostras de urina de fumantes (Figura 11) e não fumantes (Figura 12) determinada por CE e quantificada pela adição de padrão, é muito semelhante ao apresentado por Melikian et al. (1993), incluindo as faixas de concentrações. No entanto, o número de amostras analisadas por Melikian et al. (1993), $n=84$, é bem maior em relação a este trabalho, $n=29$.

Para comparação dos resultados obtidos pelas duas técnicas, oito amostras de urina foram analisadas concomitantemente pelas técnicas de HPLC e CE com adição de metanol ao eletrólito.

Os resultados apresentados na tabela XXVI demonstram que as concentrações de AM urinário obtidas por CE são mais elevadas do aquelas obtidas por HPLC, com exceção da amostra no 50 . Esta tendência da metodologia por HPLC apresentar concentrações mais baixas de AM urinário foi confirmada pela comparação com os resultados de AM obtidos em outro laboratório (no $\mathrm{CESTEH}^{1}$ )

\footnotetext{
${ }^{1}$ CESTEH, Centro de Estudos da Saúde do Trabalhador e Ecologia Humana, é um órgão da ENSPFIOCRUZ, Escola Nacional de Saúde Pública da Fundação Osvaldo Cruz.
} 
em algumas amostras de urina. O laboratório da FIOCRUZ utiliza metodologia descrita na literatura (Ducos et al., 1990). Este estudo interlaboratorial indicou que a metodologia por HPLC utilizada neste trabalho fornece concentrações menores de AM urinário. Este fato associado à possibilidade de coeluição de alguma substância com o AM quando analisado por CE pode justificar a discrepância nos resultados apresentados na Tabela XXVI. Investigações mais detalhadas deveriam ser feitas para entender melhor os resultados encontrados para as duas técnicas estudadas, entretanto deve ser lembrado que CE e HPLC são técnicas complementares. Ainda são necessários alguns estudos para se contornar alguns problemas relacionados à CE. Quando todas as variaveis que envolvem a técnica por CE estiverem controladas a metodologia poderá ser empregada em análise de rotina com grandes vantagens.

\section{TABELA XXVI - Comparação entre as concentrações de AM urinário obtidas por HPLC e por CE}

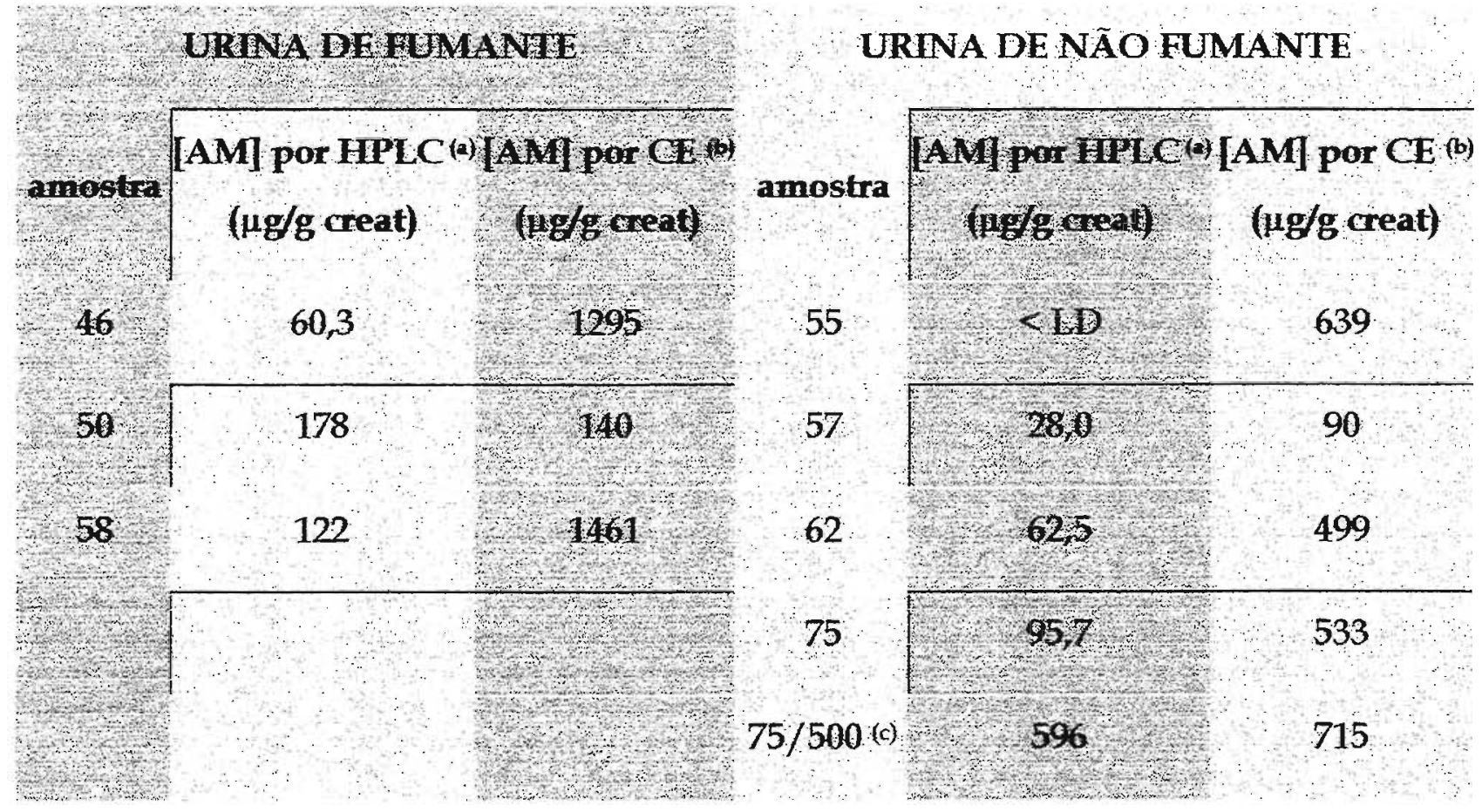

(a) Condição: coluna analítica $=$ Hibar $^{\Theta}$ RT 250-4; fase móvel $=$ metanol/HAc, $1 \%(10: 90)$; vazão $=1$ $\mathrm{mL} / \mathrm{min}$; injeção $=1 \mu \mathrm{L} ;$ deteç̧ão $=260 \mathrm{~nm}$; quantificação = método de calibração extema.

(b) Condição: capilar $=\operatorname{comum}($ d.i. $=50 \mu \mathrm{m}) ;$ eletrólito $=$ fosfato de sódio tampão pH 7,0 a 120 mmol/L + CTAB a 0,4 mmol/L + metanol a 10\%; injeção $=5$ pol de $\mathrm{Hg} / 20$ s; voltagem $=-20 \mathrm{kV}$; deteção $=260 \mathrm{~nm}$; temperatura $=25^{\circ} \mathrm{C}$; quantificação $=$ método de adição de padrão $(250,500$ e $1000 \mu \mathrm{g} / \mathrm{L})$.

(c) Amostra de urina fortificada com $500 \mu \mathrm{g} / \mathrm{L}$ de $\mathrm{AM}$ padrão. 


\section{7 - AVALIAÇÃO DAS CONDIÇŌES ANALíTICAS PARA A}

\section{DETERMINAÇÃO DE AFM EM AMOSTRAS DE URINA HUMANA POR CE}

Poucas informações sobre condições analíticas otimizadas foram obtidas para a determinação de AFM urinário pela técnica de CE-UV.

\section{1 - Avaliação da separação de AFM urinário por CE-UV}

Avaliando soluções padrões de AFM e de AM de mesma concentração, foi observado que o AM absorve cerca de 10 vezes mais do que o AFM a $262 \mathrm{~nm}$ e que a área do pico do AFM é $35 \%$ maior quando detectado a $214 \mathrm{~nm}$ (1-- máximo de absorção) em relação a $262 \mathrm{~nm}$ e $10 \%$ maior em relação a $254 \mathrm{~nm}$ (2:- máximo de absorção). No entanto, o comprimento de onda de $214 \mathrm{~nm}$ se situa em uma região do espectro na qual a maioria dos solventes absorvem.

Diversas condições empregadas para a separação de AM em amostras de urina humana por CE também foram avaliadas para a separação de AFM porém, o AFM não foi separado em nenhuma das condições avaliadas.

A condição que propiciou melhores resultados para a separação do AFM de amostras de urina, sem extração prévia, foi com adição de metanol e de dimetilformamida ao eletrólito, no entanto, não foi possível identificar o AFM na urina à concentrações inferiores a $1 \mathrm{mg} / \mathrm{L}$ e assim esta condição foi abandonada.

Para melhorar a sensibilidade da determinação foi avaliada a extração do AFM da urina em cartuchos de Sep-Pak ${ }^{\text {}}$, conforme procedimento descrito por Einig $\mathcal{E}$ Dehnen (1995). As análises dos extratos não mostraram qualquer melhora na separação do AFM. Este só pode ser identificado nas amostras de urina com adição de $100 \mathrm{mg} / \mathrm{L}$ de AFM padrão.

Um outro procedimento para a extração de AFM da urina utilizando resinas fortemente trocadoras de ânions (SAX) foi avaliado. Nas condições avaliadas, o AFM não se separou de outros compostos extraídos da urina. A verificação da presença do AFM só foi possível em amostras com mais de $10 \mathrm{mg} / \mathrm{L}$ de AFM.

Não foi possivel propor um método para a determinação de AFM urinário porque em todas as condições avaliadas o sinal do AFM só pode ser identificado quando a adição deste à urina foi realizada à altas concentrações. Para que uma 
metodologia possa ser útil para a determinação de AFM urinário com o propósito de uso como indicador biológico ela deve ter sensibilidade para detectá-lo em concentraçōes até $1 \mu \mathrm{g} / \mathrm{L}$, que é o núvel encontrado em populações de indivíduos ocupacionalmente não expostos e não fumantes. Este nível exigido é cerca de 1000 vezes menor que a menor concentração na qual o AFM pode ser identificado neste trabalho. Mesmo se tivesse sido encontrada uma condição na qual o AFM aparecesse completamente separado de outros compostos da urina, pela comparação com o AM através do sinal detectado é possível prever que dificilmente concentrações inferiores a $50 \mu \mathrm{g} / \mathrm{L}$ poderiam ser detectadas, sendo um limite muito alto para os propósitos de utilização como IBE.

Portanto para a determinação de AFM urinário por CE com base nessas investigações é necessário obter um agente fluorescente, através de derivatização, para ser detectado por fluorimetria, pois a detecção por UV-visível sem préconcentração do analito, não tem sensibilidade suficiente para esta determinação. 


\section{CONCLUSÃO}

Apesar do ácido S-fenilmercaptúrico ser um metabólito específico do benzeno e a sua determinação na urina ser indicada pela ACGIH (ACGIH, 1998) para a avaliação da exposição ao benzeno, o AM tem sido mais estudado para esta finalidade, com muitos trabalhos descritos na literatura envolvendo $o$ desenvolvimento de metodologias. Estas metodologias apresentam etapas laboriosas de limpeza da amostra.

A metodologia analítica desenvolvida neste trabalho para a determinação de AM urinário emprega a técnica de eletroforese capilar e apresenta muitas vantagens em relação às outras metodologias existentes: o tempo de análise é muito menor; a etapa de pré-tratamento da amostra se limita à uma simples filtração através de filtro com poros de $0,22 \mu \mathrm{m}$ de diâmetro, evitando manipulação intensiva com a amostra; a automação da técnica permite a análise de dezenas de amostras diariamente; o custo com reagentes é reduzido devido ao pequeno volume utilizado durante a análise.

Foram estabelecidas duas condições para esta determinação, ambas com limite de detecção em torno de $25 \mu \mathrm{g} / \mathrm{L}$. Uma delas emprega um capilar com cela ótica de alta sensibilidade, possibilitando que o sinal do AM possa ser detectado com uma sensibilidade cerca de 10 vezes maior do que no capilar comum. A outra emprega um modificador orgânico adicionado ao eletrólito, que confere maior estabilidade ao sistema.

A grande vantagem da substituição do capilar com cela ótica de alta sensibilidade por um capilar comum, utilizado na condição que emprega metanol, está na redução no custo da análise, em cem vezes.

A aplicação da metodologia desenvolvida em amostras de urina de indivíduos fumantes e não fumantes, utilizando as duas condições analíticas, apresentou sensibilidade suficiente para diferenciar estatisticamente os dois grupos avaliados. 
Apesar do número limitado de amostras, os resultados com a condição que não emprega metanol são semelhantes aos apresentados na literatura, enquanto que a outra condição apresentou concentração média de AM urinário mais elevada. A discrepância foi atribuída à diferenças no metabolismo humano e eventualmente possíveis substâncias coeluindo com o analito.

Neste trabalho, a determinação de $\mathrm{AM}$ urinário por $\mathrm{CE}$ não pode ser comparada com a determinação por HPLC. A técnica cromatográfica exigiu maior investimento de tempo e as condições ótimas de análise do AM não puderam ser estabelecidas.

Apesar de testes exaustivos, nenhuma condição analítica foi obtida para a separação do AFM por CE. 
Seguem algumas sugestões de pesquisas para dar continuidade a este trabalho:

- Comparação das duas condições analíticas para a determinação do AM por CE utilizando as mesmas amostras de urina;

- Avaliação espectrofotoquímica do AM separado por CE utilizando um detector UV-visível com dispositivo diode-array;

- Avaliação do efeito no tempo de migração e no limite de detecção, do uso de solução padrão preparada com o mesmo tampão utilizado no eletrólito para a determinação de $\mathrm{AM}$ por $\mathrm{CE}$;

- Realização de estudo interlaboratorial para comparação da metodologia por CE com uma por HPLC já estabelecida e utilizada rotineiramente;

- Estudo para diferenciar grupos de fumantes passivos e não fumantes como também, de fumantes com quantidades diferentes de cigarros consumidos, através da metodologia desenvolvida neste trabalho;

- Realização de um estudo com acompanhamento epidemiológico, para avaliar a utilização do AM urinário como IBE ocupacional ao benzeno, verificando a correlação entre a concentração ambiental de benzeno e a deste metabólito determinado na urina dos trabalhadores.

- Avaliação de procedimentos de limpeza da amostra para a extração do AFM urinário e derivatização deste com ortoftalaldeído e mercaptoetanol, ou método similar, para separação do derivado por $\mathrm{CE}$ e detecção por fluorescência.

- Desenvolver estudos de pré-concentração do AFM extraído da urina de indivíduos expostos ao benzeno.

- Desenvolver metodologia para a determinação de benzeno urinário utilizando a técnica de SPME (Solid Phase Micro-Extraction) com sensibilidade para avalialo em concentrações inferiores a $50 \mathrm{ng} / \mathrm{L}$. 


\section{REFERÊNCIAS BIBLIOGRÁFICAS}

ACGIH, American Conference of Governmental Industrial Hygienists. 1997: Threshold Limit Values for Chemical Substances and Physical Agents and Biological Exposure Indices. Cincinnati, $\mathrm{OH}$ (1998).

ALESSIO, L.; BERLIN, A.; DELL'ORTO, A.; TOFFOLETO, F.; GHEZZI, I. Reliability of urinary creatinine as a parameter used to adjust values of urinary biological indicators. Int. Arch. Occup. Environ. Health 55: 99-106 (1985).

ALTRIA, K.D. Essential peak area normalization for quantitative impurity content determination by capillary electrophoresis. Chromatographia 35: 177-182 (1993).

ANGERER, J.; HÖRSCH, B. Determination of aromatic hydrocarbons and their metabolites in human blood and urine. J. Chromatogr. 580: 229-255 (1992).

ANGERER, J.; SCHERER, G.; SCHALLER, K.H.; MÜLLER, J. The determination of benzene in human blood as an indicator of environmental exposure to volatile aromatic compounds. Fresenius J. Anal. Chem. 339: 740-742 (1991).

ANGERER, J.; SCHILDBACH, M.; KRÄMER, A. Gas chromatographic method for the simultaneous determination of S-p-toluylmercapturic acid and Sphenylmercapturic acid in human urine. J. Anal. Toxicol. 22: 211-214 (1998).

APOSTOLI, P.; ALESSIO, L. Fattori condizionanti assorbimento e metabolismo del benzene. In: 17 Benzene - Tossicologia, Ambienti di Vita e di Lavoro. (Minoia et al., eds.), p. 17-26, Morgan Edizioni Tecniche, Milano (1995).

ASTIER, A. Chromatographic determination of volatile solvents and their metabolites in urine for monitoring occupational exposure. J. Chromatogr. $\underline{643}$ : 389-398 (1993).

AVELLA, F.; CASALINI, A.; ROLLA, A. Tenore di benzene nelle benzine e sua influenza sulle emissioni degli autoveicoli. In: Il Benzene - Tossicologia, 
Referências Bibliográficas

Ambienti di Vita e di Lavoro. (Minoia et al., eds.), p. 113-124, Morgan Edizioni Tecniche, Milano (1995).

BABA, Y. Analysis of disease-causing genes and DNA-based drugs by capillary electrophoresis. Toward DNA diagnosis and gene therapy for human diseases. J. Chromatogr. B: Biomed. Appl. 687: 271-302 (1996).

BADGER, G. M. Aromatic Character and Aromaticity. Syndics of the Cambridge University Press, Cambridge (1969).

BAKER, D.R. Capillary Electrophoresis. Wiley, New York (1995).

BARALE, R. Genotossicità del benzene. In: I Benzene - Tossicologia, Ambienti di Vita e di Lavoro. (Minoia et al., eds.), p. 41-50, Morgan Edizioni Tecniche, Milano (1995).

BARTCZAK, A.; KLINE, S.A.; YU, R.; WEISEL, C.P.; GOLDSTEIN, B.D.; WITZ,G.; BECHTOLD, W.E. Evaluation of assays for the identification and quantification of muconic acid, a benzene metabolite in human urine. J. Toxicol. Environ. Health 42: 245-258 (1994).

BARTOLUCCI, G.B.; ALESSANDRO, G.; SAIA, B. Evoluzione della patologia professionale da benzene. In: II Benzene - Tossicologia, Ambienti di Vita e di Lavoro. (Minoia et al., eds.), p. 69-80, Morgan Edizioni Tecniche, Milano (1995).

BECHTOLD, W.E.; HENDERSON, R.F. Biomarkers of human exposure to benzene. J. Toxicol. Environ. Health 40: 377-386 (1993).

BECHTOLD, W.E.; LUCIER, G.; BIRNBAUM, L.S.; YTN, S.N.; LI, G.L.; HENDERSON, R.F. Muconic acid determinations in urine as a biological exposure index for workers occupationally exposed to benzene. Am. Ind. Hyg. Assoc. J. 52: $473-478$ (1991).

BLEASDALE, C.; KENNEDY, G.; MacGREGOR, J.O. NIESCHALK, J.; PEARCE, K.; WATSON, W.P.; GOLDING, B.T. Chemistry of muconaldehydes of possible 
relevance to the toxicology of benzene. Environ. Heaith Perspect. 104 (sup. 6): 1201-1209 (1996).

BOOGAARD, P.J.; VAN SITTERT, N.J. Biological monitoring of exposure to benzene a comparison between S-phenylmercapturic acid, trans,trans-muconic acid, and phenol. Occup. Environ. Med. 52: 611-620 (1995).

BOOGAARD, P.J.; VAN STTTERT, N.J. Suitability of S-phenylmercapturic acid and trans,trans-muconic acid as biomarkers for exposure to low concentrations of benzene. Environ. Health Perspect. 104: 1151-1157 (1996).

BRONDEAU. M.T.: DUCOS. P.: GAUDIN, R.: MOREL. G.; BONNET. P.; CEALRRIZ, J. Evaluation of the interaction of benzene and toluene on the urinary excretion of $t, t$-muconic acid in rats. Toxicol. Lett. 61: 311-316 (1992).

BRUGNONE, F.; PERBELLINI, L.; FACCINI, G.B.; PASINI, F.; DANZI, B.; MARANELLI, G.; ROMEO, L.; ROMEO, L.; GOBBI, M.; ZEDDE. A. Benzene in the blood and breath of normal people and occupationally exposed workers. Am. J. Ind. Med. 16: 385-399 (1989).

BRUMLEY, W.C.; BROWNRIGG, C.M. Electrophoretic behavior of aromaticcontaining organic acids and the determination of selected compounds in water and soil by capillary electrophoresis. J. Chromatogr. 646: 377-389 (1993).

BURATTI, M.; FUSTTNONI, S.; COLOMBI,A. Fast liquid chromatographic determination of urinary trans, trans-muconic acid. J. Chromatogr. B: Biomed. Appl. 677: 257-263 (1996).

BURATTI, M.; PELlEGRINO, O.;VALLA, C.; FUSTINONI, S.; COLOMBI, A. Monitoraggio biologico dellésposizione ambientale a benzene in addetti alla vigilanza urbana. Med. Lav. 8: 208-219 (1997).

CANDURA, S.M.; LA PAGLLA, G.; MANZO, L. Metabolismo e meccanismi di tossicità del benzene. In: Il Benzene - Tossicologia, Ambienti di Vita e di Lavoro. (Minoia et al., eds.), p. 3-15, Morgan Edizioni Tecniche, Milano (1995). 


\section{Referências Bibliográficas}

CASADO, A.G.; RODRIGUEZ, L.C.; HERNANDEZ, E.A.; VILCHEZ, J.L. Estimate of gas chromatographics blanks. Application to detection limits evaluation as recommended by IUPAC. J. Chromatogr. A 726: 133-139 (1996).

COCHEO, V. Evoluzione dell'esposizione ambientale a benzene. In: II Benzene Tossicologia, Ambienti di Vita e di Lavoro. (Minoia et al., eds.), p. 81-88, Morgan Edizioni Tecniche, Milano (1995).

COLLINS, C.H.; BRAGA, G.L. Introdução a Métodos Cromatográficos. $1^{\natural}$ ed., Ed. Unicamp, Campinas (1987).

COLLINS, J.J.; IRELAND, B.K.; EASTERDAY, P.A.; NAIR, R.S.; BRAUN, J. Evaluation of limphopenia among workers with low-level benzene exposure and the utility of routine data collection. J. Occup. Environ. Med. 39: 232-237 (1997).

\section{COUTRIM, M.X. Avaliação da separação das 2,4-dinitrofenilhidrazonas (DNFHo)} de aldeídos e cetonas por cromatografia líquida de alta eficiência, p. 49, Campinas (1991). [Dissertação de mestrado, Instituto de Química, UNICAMP].

COUTRIM, M.X.; NAKAMURA, L.A.; COLLINS, C.H. Quantification of 2,4dinitrophenyl-hydrazones of low molecular mass aldehydes and ketones using HPLC. Chromatographia 37: 185-190 (1993).

COUTRIM, M.X.; JAGER, A.V.; DE CARVALHO, L.R.F.; TAVARES, M.F.M. Determination of benzene metabolites by capillary electrophoresis. In: $2^{\text {nd }}$ Annual Latin-American Symposium on Biomedical, Biopharmaceutical, and Industrial Application of Capillary Electrophoresis, Santiago (1996).

COUTRIM, M.X.; JAGER, A.V.; DE CARVALHO, L.R.F.; TAVARES, M.F.M. Capillary electrophoresis determination of urinary muconic acid as a biological marker for benzene in cigarette smoke. J. Capillary Electrophor. 4: 39-45 (1997a).

COUTRIM, M.X.; JAGER, A.V.; DE CARVALHO, L.R.F.; TAVARES, M.F.M. Desenvolvimento de metodologia para a determinação de ácido mucônico na 


\section{Referências Bibliográficas}

urina por eletroforese capilar. In: 20a Reunião Anual da Sociedade Brasileira de Química, Poços de Caldas (1997b). Livro de Resumos, v. 3, p. AB 31, SBQ, São Paulo (1997).

COUTRIM, M.X.; IAGER, A.V.; DE CARVALHO, L.R.F.; TAVARES, M.F.M. New approaches for the capillary electrophoresis determination of benzene metabolites in urine. In: 3nd Annual Latin-American Symposium on Biomedical, Biopharmaceutical, and Industrial Application of Capillary Electrophoresis, Buenos Aires (1997c). Resumos, p. 41, Fundation A.L.A.C., Buenos Aires (1997).

COUTRIM, M.X.; JAGER, A.V.; DE CARVALHO, L.R.F.; TAVARES, M.F.M. Determinação de ácido trans,trans-mucônico por eletroforese capilar em urina de fumantes e não fumantes. In: COLACRO VII - 7th Latin-American Congress on Chromatography and Related Techniques, Águas de São Pedro (1998). Book of Abstracts, p. 365, Acta Eventos, São Carlos (1998).

DAIKER, D.H.; MOSLEN, M.T.; CARR, J.B.; WARD Jr., J.B. Repeated oral benzene exposure alters enzymes involved in benzene metabolism. J. Toxicol. Environ. Health 51: 439-451 (1996).

DE CARVALHO, A.B.; ARCURI, A.S.A.; BEDRIKOW, B.; AUGUSTO, L.G.S.; OLIVEIRA, L.C.C; BONCIANI, M.; KATO, M.; GRAMACHO, M.I.P.; FREITAS, N.B.B.; NOVAES, T.C.P. Benzeno: Subsidio Técnico à Secretaria de Segurança e Saúde no Trabalho. $2^{\text {a }}$ ed., FUNDACENTRO/FUNDUTNESP, São Paulo (1995).

DEVÊVRE, O.; PUTRA, D.P.; BOTTON B. GARBAYE, J. Sensitive and selective method for the separation of organic acids by capillary zone electrophoresis. J. Chromatogr. A 679: 349-357 (1994).

DUCOS, P.; GAUDIN, R.; ROBERT, A.; FRANCIN, J.M.; MAIRE, C. Improvement in HPLC analysis of urinary trans, trans-muconic acid, a promising substitute for phenol in the assessment of benzene exposure. Int. Arch. Occup. Environ. Health 62: 529-534 (1990). 


\section{Referências Bibliográficas}

DUCOS, P.; GAUDIN, R.; BEL, J.; MAIRE, C.; FRANCIN, J.M.; ROBERT, A.; WILD, P. trans,trans-Muconic acid, a reliable biological indicator for the detection of individual benzene exposure down to the ppm level. Int. Arch. Occup. Environ. Health 64: 309-313 (1992).

EINIG, T.; DUNEMANN, L.; DEHNEN, W. Sensitive gas chromatographic method for determination of mercapturic acids in human urine. J. Chromatogr. B: Biomed. Appl. 687: 379-385 (1996).

EINIG, T.; DEHNEN, W. Sensitive determination of benzene metabolite $S$ phenylmercapturic acid in urine by high-performance liquid chromatography with fluorescence detection. J. Chromatogr. A 697: 371-375 (1995).

FIORDI, T.; MUZI, G.; ABBRITTI, G. Inquinamento dell'aria interna e benzene. In: II Benzene - Tossicologia, Ambienti di Vita e di Lavoro. (Minoia et al., eds.), p. 99111, Morgan Edizioni Tecniche, Milano (1995).

FORNI, A. Benzene-induced chromosome aberrations: a follow-up study. Environ. Health Perspect. 104 (sup. 6): 1309-1312 (1996).

GHITTORI, G.; FIORENTINO, M.L.; MAESTRI, L.; CORDIOLI, G.; MMBRIANI, M. Urinary excretion of unmetabolized benzene as an indicator of benzene exposure. J. Toxicol. Environ. Health 38: 233-243 (1993).

GHITTORI, S.; MAESTRI, L.; FIORENTINO, M.L.; IMBRIANI, M. Evaluation of occupational exposure to benzene by urinalysis. Int. Arch. Occup. Health 67: 195200 (1995a).

GHITTORI, G.; FIORENTINO, M.L.; MAESTRI, L.; ZADRA, P.; IMBRIANI, M. Indicatori biologici urinari dell'esposizione a benzene. In: 11 Benzene Tossicologia, Ambienti di Vita e di Lavoro. (Minoia et al., eds.), p. 347-357, Morgan Edizioni Tecniche, Milano (1995b).

GHITTORI, S.; MAESTRI, L.; ROLANDI, L.; LODOLA, L.; FIORENTINO, M.L.; IMBRIANI, M. The determination of trans, trans-muconic acid in urine as an 
indicator of occupational exposure to benzene. Appl. Occup. Environ. Hyg. 11: 187-191 (1996).

GILLI, G.; SCURSATONE, E.; BONO, R. Geographical distribution of benzene in air in northwestern Italy and personal exposure. Environ. Health Perspect. 104 (sup. 6): 1137-1140 (1996).

GOBBA, F.; ROVESTI, S.; BORELLA, P.; VIVOLI, R.; CASELGRANDI, E.; VIVOLI, G. Inter-individual variability of benzene metabolism to trans, trans-muconic acid and its implications in the biological monitoring of occupational exposure. Sci. Total Environ. 199: 41-48 (1997).

GOLDSTEIN, B.D. Introduction: occam's razor is dull. Environ. Health Perspect. $\underline{\text { 82: }}$ 3-6 (1989).

GREENLEE, W.F.; SUN, J.D.; BUS, J.S. A proposed mechanism for benzene toxicity: formation of reactive intermediates for polyphenol metabolites. Toxicol. Appl. Pharmacol. 모: 187-195 (1981).

GROTZ, V.L.; II, S.; KLINE, S.A.; GOLSTEIN, B.D.; WITZ, G. Metabolism of benzene and trans,trans-muconaldehyde in the isolated perfused rat liver. Toxicol. Lett. 70: 281-290 (1994).

GUZMAN, N.A.; GONZALES, C.L.; TREBILCOCK, M.A.; HERNANDEZ， L.; BERCK,C.M.; ADVIS, J.P. The use of capillary electrophoresis in clinical diagnosis. In: Capillary Electrophoresis Technology, p. 643-672 (Guzman, N.A., ed.) Marcel Dekker, Inc., New York (1993).

GUZMAN, N.A., ed. Capillary Electrophoresis Technology. Marcel Dekker, Inc., New York, (1993).

HAJMIRAGHA, H.; EWERS, U. BROCKHAUS, A.; BOETTGER, A. Levels of benzene and other volatile aromatic compounds in the blood of non-smokers and smokers. Int. Arch. Occup. Health 61: 513-518 (1989). 
Referências Bibliográficas

HAUFROID, V.; HOTZ, P.; CARBONNELLE, P.; LAUWERYS, R. Relationships between smoking habits, smoking-associated hematological changes, and urinary benzene metabolites. J. Toxicol. Environ. Health 52: 1-17(1997).

HEIGER, D.N. High performance capillary electrophoresis. Hewlett-Packard Co., Wald bronn (1992). [Publicação no 12-5091-6199E].

HENDERSON, R.F.; SABOURIN, P.J.; BECHTOLD, W.E.; GRIFFITH, W.C; MEDINSKY, M.A.; BIRBAUM, L.S.; LUCIER, G.W. The effect of dose, dose rate, route of administration, and species on tissue and blood levels of benzene

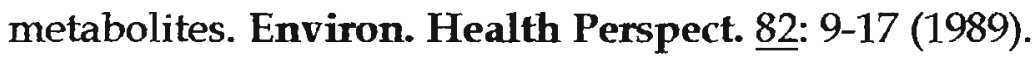

HENDERSON, R.F. Strategies for use of biological markers of exposure. Toxicol. Lett. 379: 379-383 (1995).

HENDERSON, R.F. Species differences in the metabolism of benzene. Environ. Health Perspect. 104 (sup. 6): 1173-1175 (1996).

HINSON, J.A.; FREEMAN, J.P.; POTTER, D.W.; MTTCHUM, R.K.; EVANS, F.E. Mechanism of microsomal metabolism of benzene to phenol. Mol. Pharmacol. 27: 574-577 (1985).

HOYT Jr., A.M.H.; Quantitative analysis with capillary zone electrophoresis. In: Capillary electrophoresis technology, p. 705-714 (Guzman, N.A., ed.), Marcel Dekker, Inc., New York (1993).

INOUE, O.; SEIJE, K.; NAKATSUKA, H.; WATANABE, T.; YIN, S.-N.; LI, G.-L.; CAI, S.-X.; JIN, C.; IKEDA, M. Urinary $t, t$-muconic acid as indicator of exposure to benzene. Br. J. Ind. Med. 뜨: 122-127 (1989a).

INOUE, O.; SEIII, K.; NAKATSUKA, H.; WANTABLE, T.; YIN, S.N.; LI, G.L.; CAI, S.X.; JIN, C; IKEDA, M. Excretion of 1,2,4-Benzenetriol in the urine of workers exposed to benzene. Br. J. Ind. Med. $\underline{46}$ : 559-565 (1989b). 


\section{Roferências Bibliográficas}

IAFFE, M, Über die aufspaltung des benzolrings im organismus. I - Das auftreten von muconsäure im harn nach darreichung von benzol. Hoppe-Seyler's Z. Physiol. Chem. 62: 58-67 (1909).

JANINI, G.M.; ISSAQ, H.J. The buffer in capillary zone electrophoresis. In: Capillary electrophoresis technology, p. 119-160, (Guzman, N.A., ed.), Marcel Dekker, Inc., New York (1993).

JAVELAUD, B.; VIAN, L.; MOLLE, R.; ALLAIN, P.; ALLEMAND, B.; ANDRE, B.; BARBIER, F.; CHURET, A.M.; DUPUIS, J.; GALAND, M.; MILLET, F.; TALMON, J.; TOURON, C.; VAISSIÉRE, D.; VECHAMBRE, D.; VIEULES, M.; VIVER, D. Benzene exposure in car mechanics and road tanker drivers. Int. Arch. Environ. Health 71:277-283 (1998).

JELLUM, E.; DOLLEKAMP, H.; BLESSUM, C. Capillary electrophoresis for clinical problem solving: analysis of urinary diagnostic metabolites and serum proteins. J. Chromatogr. B: Biomed. Appl. 683: 55-65 (1996).

JOHNSON E.S.; LUCIER, G. Perspective on risk assessment impact of recent reports on benzene. Am. J. Ind. Med. 21: 749-757 (1992).

JONGENEELEN, F.J.; DIRVEN, H.A.A.M.; LEIJDEKKERS, C.-M.; HENDERSON, P.T. S-Phenyl-N-acetylcysteine in urine of rats and workers after exposure to benzene. J. Anal. Toxicol. 11: 100-104 (1987).

KARACIC, V.; SKENDER, L.; CUCANCIC, B.-B.; SARE, A.-B. Possible genotoxicity in low level benzene exposure. Am. J. Ind. Med. 27: 379-388 (1995).

KENNDLER, E.; JENNER, P. Isotachophoresis in mixed solvents, consisting of water, methanol and dimethyl sulphoxide. I - The acid-base and migration behavior of substituted benzenecarboxylic acids. J. Chromatogr. $\underline{390}$ : 169-183 (1987).

KENNDLER, E.; JENNER, P. Isotachophoresis in mixed solvents, consisting of water, methanol and dimethyl sulphoxide. III - Influence of the solvent 


\section{Referências Bibliográficas}

composition on the dissociation constants and mobilities of non- and hydroxysubstituted aliphatic carboxylic acids. J. Chromatogr. $\underline{470:}$ 57-68 (1989).

KENNDLER, E. Organic solvents in capillary electrophoresis. In: Capillary electrophoresis technology, p. 161-186 (Guzman, N.A. ed.) Marcel Dekker, Inc., New York, (1993).

KENNEY, B.F. Determination of organic acids in food samples by capillary electrophoresis. J. Chromatogr. 546: 423-430 (1991).

KIVISTÖ, H.; PEKARI, K.; PELTONEN, K.; SVINHUFVUD, J.; VEIDEBAUM, T.; SORSA, M.; AITIO, A. Biological monitoring of exposure to benzene in the production of benzene and in a cokery. Sci. Total Environ. 199: 49-63 (1997).

KOK, P.W.; ONG, C.N. Blood and urinary benzene determined by headspace gas chromatography with photoionization detection: application in biological monitoring of low-level non occupational exposure. Int. Arch. Occup. Environ. Health 66: 195-201 (1994).

KOK, P.W.; ONG, M.K.; WONG, W.K.; AU, K.T.; PHDOON, W.H.; ONG, C.N. Environmental and biological assessment of exposure to benzene in petroleum workers. Environ. Monit. Assess. 44: 425-431 (1997).

KUSELMAN, I.; SHENHAR, A. Design of experiment for the determination of the detection limit in chemical analysis. Anal. Chim. Acta 306: 301-305 (1995).

LARSEN J.C. Levels of pollutants and their metabolites: exposures to organic substances. Toxicology 101: 11-27 (1995).

LAUWERYS, R.R.; BUCHET, J.-P.; ANDRIEN, F. Muconic acid in urine: a reliable indicator of occupational exposure to benzene. Am. J. Ind. Med. 25: 297-300 (1994).

LEE, B.-L.; NEW, A.-L.; KOK, P.-W.; ONG, H.-Y.; SHI, C.-Y.; ONG, C.-N. Urinary trans,trans-muconic acid determined by liquid chromatography: application in biological monitoring of benzene exposure. Clin. Chem. 39: 1788-1792 (1993). 
LINET, M.S.; YIN, S.-N.; TRAVIS, L.B.; LI, C.-Y.; ZHANG, Z.-N.; LI, D.-G.; ROTHMAN, N.; LI. G.-L.; CHOW, W.-H.; DONALDSON, J.; DOSEMECI, M.; WACHOLDER, S.; BLOT, W.J.; HAYES, R.B. Clinical features of hematopoietic malignancies and related disorders among benzene-exposed workers in China. Environ. Health Perspect. 104 (sup. 6): 1353-1364 (1996).

LOCATELLI, C.; MACCARINI, D.; BUTERA, R.; VARANGO, C.; MANZO, L. Tossicologia clinica del benzene negli inicidenti chimici industriali e ambientali. In: 11 Benzene - Tossicologia, Ambienti di Vita e di Lavoro. (Minoia et al., eds.), p. 27-39, Morgan Edizioni Tecniche, Milano (1995).

MAESTRI, L.; BHITTORI, S.; GRIGNANI, E.; FIORENTINO M.L.; IMBRIANI, M. Dosaggio di un metabolita del benzene l'acido S-fenilmercapturico urinario (SPMA), nell'uomo, mediante HPLC. Med. Lav. 84: 55-65 (1993).

MAESTRI, L.; GHITTORI, S.; FIORENTINO, M.L.; IMBRIANI, M. II dosaggio dell'acido trans, trans-muconico urinario a basse concentrazioni. Med. Lav. $\underline{86}$ : 4049 (1995).

MAESTRI, L.; COCCINI, T.; MMBRIANI, M.; GHITTORI, S.; MANZO, L. BIN, L.; PEZZAGNO, G. Effects of sorbic acid ingestion on urinary excretion of trans, transmuconic acid in human volunteers and in rats exposed to low concentration of benzene. Toxicol. Lett. $\underline{88}$ (Supl.1): 43 (1996).

MAESTRI, L.; GHITTORI, S.; IMBRIANI, M. Determination of specific mercapturic acids as an index of exposure to environmental benzene, toluene and styrene. Ind. Health 35: 489-501 (1997).

MARINA, M.L.; TORRE, M. Capillary electrophoresis. Talanta 41: 1411-1433 (1994).

MARSH, D.B.; NUTTALL, K.L. Methylmalonic acid in clinical urine specimens by capillary zone electrophoresis using indirect photometric detection. J. Capillary Electrophor. 2: 63-67 (1995).

MASTRANGELO, G. Modelli di tipo epidemiologico per lo studio della cancerogenesi da benzene in ambiente lavorativo. In: 11 Benzene - Tossicologia, 
Ambienti di Vita e di Lavoro. (Minoia et al., eds.), p. 51-62, Morgan Edizioni Tecniche, Milano (1995).

MEDEIROS, A.M.; BIRD, M.G.; WITZ, G. Potential biomarkers of benzene exposure. T. Toxicol. Environ. Health 51: 519-539 (1997).

MELIKIAN, A.A.; PRAHALAD, A.K.; HOFFMANN, D. Urinarv trans, trans-muconic acid as an indicator of exposure to benzene in cigarette smokers. Cancer Epidemiol. Biomarkers Prev. 2: 47-51 (1993).

MILLER, J.C.; MILLER, J.N. Statistics for Analytical Chemistry. 3a ed., Ellis Horwood, New York (1993).

MONEY, C.D.; GRAY, C.N. Exhaled breath analysis as a measure of workplace exposure to benzene ppm. Ann. Occup. Hyg. 33: 257-262 (1989).

MONNING, C.A.; KENNEDY, R.T. Capillary electrophoresis. Anal. Chem. 66: 280R$314 R(1994)$.

MORING, S.E.; PAIRAIUD, C.; ALBIN, M.; LOCKE, S.; THIBAULT, P.; TINDALL, G.W. Enhancement of UV detection sensitivity for capillary electrophoresis with high-sensitivity optical cell. American Laboratory, Perkin Elmer, (1993). [Technical Bulletin n. 600128]

NILSSON, R.I.; NORDLINDER, R.G.; TAGESSON, C.; WALLES, S.; JÄRVHOLM, B.G. Genotoxic effects in workers exposed to low levels of benzene from gasoline. Am. J. Ind. Med. 30: 317-324 (1996).

NORPOTH, K.; STÜCKER, W.; KREWET, E.; MÜLLER, G. Biomonitoring of benzene exposure by traces analyses of phenylguanine. Int. Arch. Occup. Environ. Health 60: 163-168 (1988).

NORPOTH, K.H.; MÜLLER, G.; SCHELL, C; JORG, E. Phenylguanine found in urine after benzene exposure. Environ. Health Perspect. 104 (sup. 6): 1159-1163 (1996). 
ONG, C.N.; LEE, B.L.; SHI, C.Y.; ONG, H.Y.; LEE, H.P. Elevated levels of benzenerelated compounds in the urine of cigarette smokers. Int. J. Cancer 59: 177-180 (1994).

ONG, C.N.; LEE, B.L. Determination of benzene and its metabolites: Application in biological monitoring of environmental and occupational exposure to benzene. J. Chromatogr. B: Biomed. Appl. 660: 1-22 (1994).

ONG, C.N.; KOK, P.W.; LEE, B.L.; SHI, C.Y.; ONG, H.Y.; CHIA, K.S.; LEE, C.S.; LUO, X.W. Evaluation of biomarkers for occupational exposure to benzene. Occup. Environ. Med. 52: 528-533 (1995).

ONG, C.N.; KOK, P.W.; ONG, C.Y.; SHI, C.Y.; LEE, B.L.; PHOON, W.H.; TAN, K.T. Biomarkers of exposure to low concentrations of benzene: a field assessment. Occup. Environ. Med. 53: 328-333 (1996).

PARKE, D.V.; WILLIAMS, R.T. Studies in detoxication 38. The metabolism of benzene. A) The determination of phenylmercapturic acid in urine. B) Mercapturic acid excretion by rabbits receiving benzene. Biochem. J. $\underline{48}$ : 624-629 (1951).

PARKE, D.V.; WILLIAMS, R.T. Detoxication XLIV. Metabolism of benzene. The muconic acid excretion by rabbits receiving benzene. Biochem. J. 51: 339-348 (1952).

PARKE, D.V. Personal reflections on 50 years of study of benzene toxicology. Environ. Health Perspect. 104 (sup. 6): 1123-1128 (1996).

PEKARI，K.; VAINIOTALO, S.; HEIKKILÄ, P.; PALOTIE, A.; LUOTAMO, M.; RIIHIMÄKI, V. Biological monitoring of occupational exposure to low levels of benzene. Scand. J. Work Environ. Health 18: 317-322 (1992).

PEKARI, K. Biological Monitoring of Benzene, Toluene and Styrene. Helsinki (1994). [Academic Dissertation, Faculty of Natural and Environmental Sciences, University of Kiopio] 


\section{Referências Bibliográficas}

PELLACK-WALKER, P.; BLUMER, J.L. DNA damage in L5178YS cells following exposure to benzene metabolites. Mol. Pharmacol. 30: 42-47 (1986).

PERBELLINI, G.; FACCINI, G.B.; PASINI, F.; CAZZOLI, F.; PISTOIA, S.; ROSELLINI, R.; VALSELCCHI, M.; BRUGNONE, F. Environmental and occupational exposure to benzene by analysis of breath and blood. Br. J. Ind. Med. 45: 345-352 (1988).

PETUCCI, C.J.; KANTES, H.L.; STREIN, T.G.; VEENING, H. Capillary electrophoresis as a clinical tool determination of organic anions in normal and ureic serum using photodiode-array detection. J. Chromatogr. B: Biomed. Appl. 668: 241-251 (1995).

PEZZAGNO, G. Monitoraggio biologico delle popolazioni esposte a benzene. In: II Benzene - Tossicologia, Ambienti di Vita e di Lavoro. (Minoia et al., eds.), p. 125-145, Morgan Edizioni Tecniche, Milano (1995).

POPP, W.; RAUSCHER, D.; MÜLLER, G.; ANGERER, J.; NORPOTH, K. Concentrations of benzene in blood and S-phenylmercapturic and $t, t$-muconic acid in urine in car mechanics. Int. Arch. Occup. Environ. Health 66: 1-6 (1994).

REID, R.H.P. Electrophoretic behavior of a group of organic anions of biochemical interest in a functionally coherent series of buffers. J. Chromatogr. A $\underline{669}$ : 151-183 (1994).

REUTERWALL, C.; ARINGER, L.; ELINDER, C.-G.; RANNUNG, a; LEVIN, J.-O.; JURING, L.; ÖNFELT, A. Assessment of genotoxic exposure in Swedish coke-oven work by different methods of biological monitoring. Scand. J. Work Environ. Health 17: 123-132 (1991).

RIEDEL, K.; RUPPERT, T.; CONZE, C.; SCHERER, G.; ADLKOFER, F. Determination of benzene and alkylated benzenes in ambient and exhaled air by microwave desorption coupled with gas chromatography-mass spectrometry. J. Chromatogr. A 719: 383-389 (1996). 


\section{Referências Bibliográficas}

ROMANO J.; JANDIK, P.; JONES, W.R.; JACKSON, P.E. Optimization of inorganic capillary electrophoresis for the analysis of anionic solutes in real samples. J. Chromatogr. 546: 411-421 (1991).

RUPPERT, T.; SCHERER, G.; TRICKER, A.R.; RAUSCHER, D.; ADLKOFER, F. Determination of urinary trans, trans-muconic acid by gas chromatography-mass spectrometry. J. Chromatogr. B: Biomed. Appl. 666: 71-76 (1995).

RUPPERT, T.; SCHERER, G.; TRICKER, A.R.; ADLKOFER, F. trans,trans-Muconic acid as a biomarker of non-occupational environmental exposure to benzene. Int. Arch. Occup. Environ. Health 69: 247-251 (1997).

SALGADO, P.E.T.; PEZZAGNO, G. Indicadores biológicos de exposição ao benzeno. Rev. Bras. Saúde Ocup. 19: 25-31 (1991).

SALOMON, K.; BURGI, D.S.; HELMER, J.C. Evaluation of fundamental properties of silica capillary used for capillary electrophoresis. J. Chromatogr. 559: 69-80 (1991).

SCHAD, H.; SCHÄFER, F.; WEBER, L.; SEIDEL, H.J. Determination of benzene metabolites in urine of mice by solid-phase extraction and high-performance liquid chromatography. J. Chromatogr. 593: 147-151 (1992).

SCHÄFER, F.; SCHAD, H.; WEBER, L. Determination of phenylmercapturic acid in urine of benzene-exposed BDF-1 mice. J. Chromatogr. 620: 239-242 (1993).

SCHERER, G.; RUPPERT, T.; DAUBE, H.; KOSSIEN, I.; RIEDEL, K.; TRICKER, A.R.; ADLKOFER, F. Contribution of tobacco smoke to environmental benzene exposure in Germany. Environ. Int. 21: $779-789$ (1995).

SCHNEEDE, J.; MOERTENSEN, J.H.; KVALHEIM, G.; UELAND, P.M. Capillary zone electrophoresis with laser-induced fluorescence detection for analysis of methylmalonic acid and other short-chain dicarboxylic acids derivatized with 1pyrenyldiazomethane. J. Chromatogr. A 669: 185-193 (1994). 
Referências Bibliográficas

SCHULTE, P.A.; TALASKA, G. Validity criteria for the use of biological markers of exposure to chemical agents in environmental epidemiology. Toxicology 101: 7388 (1995).

SHIRAO, M.; FURURA, R.; SUZUKI, S.; NAKAZAWA, H.; FUTITA, S.; MARUYAMA, T. Determination of organic acids in urine by capillary zone electrophoresis. J. Chromatogr. A 680: 247-251 (1994).

SMITH, M.T. The mechanism of benzene-induced leukemia: a hypothesis and speculations on the causes of leukemia. Environ. Health Perspect. 104 (sup. 6): 1219-1225 (1996).

SNYDER, R.; HEDLI, C.C. An Overview of benzene metabolism. Environ. Health Perspect. 104 (sup. 6): 1165-1171 (1996).

STOMMEL, P.; MÜLLER, G.; STÜCKER, W.; VERKOYEN, C.; SCHÖBEL, S.; NORPOTH, K. Determination of S-phenylmercapturic acid in the urine - an improvement in the biological monitoring of benzene exposure. Carcinogenesis 10: 279-282 (1989).

STREETER, V.L. Mecânica dos Fluidos. McGraw-Hill do Brasil, São Paulo, p. 242-3 (1974).

TAVARES, M.F.M.; MCGUFFIN, V.L.; Theoretical model of electroosmotic flow for capillary zone electrophoresis. Anal. Chem. 67: 3687-3696 (1995).

TAVARES, M.F.M. Eletroforese capilar: conceitos básicos. Quim. Nova 19: 173-181 (1996).

TAVARES M.F.M.; COLOMBARA R.; MASSAROS. Modified electroosmotic flow by cationic surfactant additives in capillary electrophoresis: an evaluation of electrolyte systems for anion analysis. J. Chromatogr. A 772: 171-178 (1997).

TIMBRELL, J.A.; MTTCHELL, J.R. Toxicity-related changes in benzene metabolism in vivo. Xenobiotica 7: 415-423 (1977). 
Referências Bibliográficas

TUNCA, B.T.; EGELI, Ü. Cytogenetic findings on shoe workers exposed long-term to benzene. Environ. Health Perspect. 104 (sup. 6): 1313-1317 (1996).

TUNEK, A.; PLATT, K.L.; BENTLEY, P.; OESCH F. Microsomal metabolism of benzene to species irreversibly binding to microsomal protein and affects of modifications of this metabolism. Mol. Pharmacol. 14: 920-929 (1978).

TÜRKEL, B.; EGELI, U. Analysis of chromosomal aberrations in shoe workers exposed long term to benzene. Occup. Environ. Med. 51: 50-53 (1994).

VAN SITTERT, N.J.; BOOGAARD, P.J.; BEULINK, G.D. Application of the urinary S-phenylmercapturic acid test as a biomarker for low levels of exposure to benzene in industry. Br. J. Ind. Med. 50: 460-469 (1993).

WAHRENDORF, J. Design of studies for validation of biomarkers of exposure and their effective use in environmental epidemiology. Toxicology 101: $89-92$ (1995).

WALLACE, L.A.; PELLEZZARI, E.D.; HARTWELL, T.D.; SPARACINO, C.M.; SHELDON, L.S.; ZELON, H. Personal exposures, indoor-outdoor relationships, and breath levels of toxic air pollutants measured for 355 persons in New Jersey. Atmos. Environ. 19: 1651-1661 (1985).

WALLACE, L.; PELLIZZARI, E.; HARTWELL, T.D.; PERRITT, R.; ZIEGENFUS, R. Exposure to benzene and other volatile compounds from active and passive smoking. Arch. Environ. Health 42: 272-279 (1987).

WALLACE, L. Environmental exposure to benzene: an update. Environ. Health Perspect. 104 (sup. 6): 1129-1136 (1996).

WÄTZIG, H. Appropriate calibration functions for capillary electrophoresis. IPrecision and sensitivity using peak areas and heights. J. Chromatogr. A $\underline{700}$ : 1-7 (1995).

WEAVER, V.M.; DAVOLI, C.T.; HELLER, P.J.; FTTZWILLIAM, A.; PETERS, H.L.; SUNYER, J.; MURPHY, S.E.; GOLDSTEIN, G.W.; GROOPMAN, J.D. Benzene 


\section{Referências Bibliográficas}

exposure, assessed by urinary trans, trans-muconic acid, in urban children with elevated blood lead levels. Environ. Health Perspect. 104: 318-323 (1996).

WESTER, R.C.; MAIBACH, H.I.; GRUENKE, L.D.; CRAIG, J.C. Benzene levels in ambient air and breath of smokers and nonsmokers in urban and pristine environments. J. Toxicol. Environ. Health 18: 567-573 (1986).

WHO - WORD HEALTH ORGANIZATION. Guiding principles for the use of biological markers in the assessment of human exposure to environmental factors: an integrative approach of epidemiology and toxicology. Toxicology 101:1-10 (1995).

WILDMAN, B.J.; JACKSON, P.E.; JONES, W.R.; ALDEN, P.G. Analysis of anion constituents of urine by inorganic capillary electrophoresis. J. Chromatogr. $\underline{546}$ : 459-466 (1991).

WITZ, G.; KIRLEY, T.A.; MANIARA, W.M.; MYLAVARAPU, V.J.; GOLDSTEIN, B.D. The metabolism of benzene to muconic acid, a potential biological marker of benzene exposure. Adv. Exp. Med. Biol. 283: 613-618 (1991).

WITZ, G.; ZHANG, Z.; GOLDSTEIN, B.D. Reactive ring-opened aldehyde metabolites in benzene hematotoxicity. Environ. Health Perspect. 104 (sup. 6): 1195-1199 (1996).

XU, Y. Capillary Electrophoresis. Anal. Chem. 67: 463R-473R (1995).

YARDLEY-JONES, A.; ANDERSON, D.; PARKE, D.V. The toxicity of benzene and its metabolism and molecular pathology in human risk assessment. Br. J. Ind. Med. 48: 437-444 (1991).

YU, R.; WEISEL, C.P. Measurement of the urinary benzene metabolite trans, transmuconic acid from benzene exposure in humans. J. Toxicol. Environ. Health $\underline{48}$ : 453-477 (1996).

ZARZYCKI, P.K.; KOWALSKI, P.; NOWAKOWSKA, J.; L.A.,PARCZYK, H. Highperformance liquid chromatography and capillary electrophoretic determination 
Referências Bibliográficas

of free nicotinic acid in human plasma and separation of its metabolites by capillary electrophoresis. J. Chromatogr. A 709: 203-208 (1995).

ZHANG, Z.; XIANG, Q.; GLATT, H.; PLATT, K.L.; GOLDSTEIN, B.D.; WITZ, G. Studies on pathways of ring opening of benzene in a fenton system. Free Radical Biol. Med. 18: 411-419 (1995).

ZIELINSKA-PSUJA, B.; ORLOWSKI, J. The influence of various mixtures of inhaled benzene and toluene and xylene on the biological monitoring of exposure. Toxicol. Lett. 78 (Supl.1): 87 (1995). 


\section{INTRODUÇÃO}

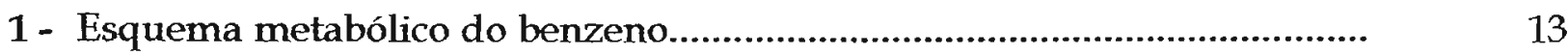

2 - Esquema representativo de um equipamento de eletroforese capilar........ 28

3 - Representação esquemática da migração de espécies aniônicas, cationicas e neutras através do eletrólito dentro do capilar, devido ao fluxo eletroosmótico e mobilidades eletroforéticas.

4 - Esquema do processo de reversão do fluxo eletroosmótico dentro do capilar devido à adição de um surfactante catiônico ao eletrólito.

\section{RESULTADOS E DISCUSSÃO}

1 - Cromatograma de $10 \mu \mathrm{L}$ de uma solução padrão contendo $10 \mu \mathrm{g} / \mathrm{L}$ de AM (coluna analítica Shim-pack CLC-ODS; $\mathrm{MeOH} / \mathrm{Hac}, 1 \%, 10: 90, \mathrm{v} / \mathrm{v}$; vazão $=1 \mathrm{~mL} /$ min e detecção $=260 \mathrm{~nm}$ ).

2 - Curva analítica de soluções padrões de $\mathrm{AM}$ com concentrações entre 1 $\mu \mathrm{g} / \mathrm{L}$ e $1000 \mu \mathrm{g} / \mathrm{L}$, determinadas por HPLC.

3 - Cromatogramas de amostras de urina sem tratamento prévio: $A$ e $B$ urina; C - AM padrão $(1000 \mu \mathrm{g} / \mathrm{L})$. Condições: injeção $=10 \mu \mathrm{L}$; coluna Shim-pack CLC-ODS; fase móvel $=\mathrm{MeOH} / \mathrm{Hac}, 1 \%$; gradiente linear em relação ao metanol $=30 \%$ por $5 \mathrm{~min}$, de $30 \%$ a $70 \%$ em $25 \mathrm{~min}, 70 \%$ por $10 \mathrm{~min}$, de $70 \%$ a $30 \%$ em $20 \mathrm{~min}$; vazão $=1 \mathrm{~mL} / \mathrm{min}$; detecção $=$ $260 \mathrm{~nm}$

4 - Cromatogramas de extratos eluídos de cartuchos com SAX: A - urina de indivíduo não fumante; B - solução padrão de $\mathrm{AM}$ a $500 \mu \mathrm{g} / \mathrm{L} ; \mathrm{C}$ urina de indivíduo não fumante contaminada com $500 \mu \mathrm{g} / \mathrm{L}$ de $\mathrm{AM}$. Condiçôes: volume injetado: $10 \mu \mathrm{L}$; coluna analítica: $\mathrm{Hibar}^{\circledR} \mathrm{RT} 250-4$; fase móvel: $\mathrm{MeOH} / \mathrm{HAc}, 1 \%(10: 90, \mathrm{v} / \mathrm{v})$; vazão: $1 \mathrm{~mL} / \mathrm{min}$; deteç̧ão: $260 \mathrm{~nm}$

5 - Eletroferogramas de solução padrão de $\mathrm{AM} 500 \mu \mathrm{g} / \mathrm{L}$ e de urina de indivíduo não fumante, com e sem adição de $500 \mu \mathrm{g} / \mathrm{L}$ de $\mathrm{AM}$, obtidos com emprego de capilar com cela ótica de alta sensibilidade e eletrólito sem metanol. 
6 - Eletroferogramas de solução padrão de AM $500 \mu \mathrm{g} / \mathrm{L}$ e de urina de individuo fumante, com e sem adição de $500 \mu \mathrm{g} / \mathrm{L}$ de $\mathrm{AM}$, obtidos com emprego de capilar com cela ótica de alta sensibilidade e eletrólito sem metanol.

7 - Eletroferogramas de urina de indivíduo não fumante sem adição de padrão e com adição de AM a 250, 500 e $1000 \mu \mathrm{g} / \mathrm{L}$, obtidos com capilar de súlica comum (caminho ótico $=50 \mu \mathrm{m}$ ) e com adição de metanol ao eletrólito.

8 - Eletroferogramas de urina de indivíduo fumante sem adição de padrão e com adição de AM a 250, 500 e $1000 \mu \mathrm{g} / \mathrm{L}$, obtidos com capilar de sílica comum (caminho ótico $=50 \mu \mathrm{m}$ ) e com adição de metanol ao eletrólito.

9 - Curva analítica para quantificação do AM pelo método da calibração externa ( 9 replicatas).

10 - Curva analítica para a determinação de AM urinário pelo método da adição de Padrão (AM adicionado =0, 250, 500 e $1000 \mu \mathrm{g} / \mathrm{L}$ )

11 - Concentração de AM em urina de fumantes determinada por quatro métodos diferentes: 1) $\mathrm{CE}$ com metanol e quantificado por adição de padrão; 2) CE com metanol e quantificado por calibração externa; 3) HPLC com eluição por gradiente e 4) HPLC com eluição isocrática.

12 - Concentração de AM em urina de não fumantes determinada por quatro métodos diferentes: 1) $\mathrm{CE}$ com metanol e quantificado por adição de padrão; 2) $\mathrm{CE}$ com metanol e quantificado por calibração externa; 3) HPLC com eluição por gradiente e 4) HPLC com eluição isocrática. 


\section{LISTA DE TABELAS}

I - Propriedades físicas do benzeno.

II - Metodologias para a determinação de ácido trans,trans-mucônico urinário

III - Metodologias para a determinação de ácido S-fenilmercaptúrico urinário.

IV - Classificação das amostras de urina por sexo, hábito de fumar, idade e período da coleta.

V - Avaliação da reutilização dos cartuchos SAX pela área e altura do pico do AM em vários tipos de amostras.

VI - Concentração de creatinina na urina de indivíduos fumantes e não fumantes.

VII - Ácido mucônico urinário, em $\mu \mathrm{g} / \mathrm{L}$ de urina, determinado por HPLC com modo isocrático de eluição empregando a coluna Ultrasphere ODS.

VIII - Ácido mucônico na urina de indivíduos fumantes e não fumantes, em $\mu \mathrm{g} / \mathrm{g}$ de creat, determinado por HPLC com eluição isocrática e coluna Ultrasphere ODS.

DX - Ácido mucônico urinário, em $\mu \mathrm{g} / \mathrm{g}$ de creat, determinado por HPLC $^{(a)}$ com eluição isocrática empregando a coluna Hibar RT $^{\circledast} 250-4$.

$X$ - Ácido mucônico urinário, em $\mu \mathrm{g} / \mathrm{g}$ de creat, determinado por HPLC com eluição por gradiente empregando a coluna Ultrasphere ODS.......

XI - Comparação dos resultados de concentração de ácido mucônico urinário determinado por HPLC..

XII - Comparação entre os modos de injeção nas análises de soluções padrões de $\mathrm{AM}$ por $\mathrm{CE}$.

XIII - Comparação entre os modos de injeção eletrocinético e por pressão para a análise de ácido mucônico em soluções padrões por CE.

XIV - Comparação do sinal de AM de soluções padrões injetadas por pressão em 28/08/96, com variações de concentração e tempo de injeção. 
XV - Comparação do sinal de AM de soluções padrões injetadas por pressão em 03/09/96, com variações de concentração e tempo de injeção.

XVI - Repetibilidade do sinal de AM em amostras de urina avaliadas no mesmo dia e em dias diferentes por $C E$.

XVII - Avaliação da diferença entre as concentrações de AM, calculada e determinada por $\mathrm{CE}$ pelo método da calibração externa, em amostras de urina fortificadas com AM.

XVIII - Concentração de AM urinário determinado por $\mathrm{CE}$, sem adição de modificador orgânico ao eletrólito.

XIX - Avaliação da repetibilidade das injeções de urina para a determinação de $A M$ urinário por $C E$, com modificador orgânico.

XX - Avaliação da recuperação de AM urinário quantificado pelo método da adição de padrão.

XXI - AM urinário quantificado por calibração externa

XXII - AM urinário quantificado por adição de padrão

XXIII - Comparação entre as concentrações de AM urinário obtidas pelos dois métodos de quantificação utilizados.

XXIV - Comparação dos sinais obtidos para o ácido mucônico por eletroforese capilar em diferentes condições de análise.

XXV - Concentrações de AM na urina de fumantes e não fumantes determinadas em diversos estudos. 


\section{APÊNDICES}

\section{Apêndice I - DETERMINAÇÃO DO TEOR DE CREATININA EM AMOSTRAS DE URINA}

A creatinina foi determinada nas amostras de urina conforme metodologia analítica adquirida junto à FUNDACENTRO.

O método se baseia na redução do ácido pícrico pela creatinina em meio alcalino, formando o ácido pícrâmico, o qual apresenta uma coloração vermelhoalaranjada, que é medida espectrofotometricamente.

\section{Reagentes}

1. Ácido pícrico $1 \%, \mathrm{p} / \mathrm{v}$ - Cerca de $2 \mathrm{~g}$ de ácido pícrico, $\mathrm{PA}$, pesados com precisão de 0,02 $\mathrm{mg}$, foram dissolvidas em $95 \mathrm{~mL}$ de água deionizada em um balão volumétrico de $200 \mathrm{~mL}$. A solução resultante foi deixada em repouso durante à noite. No outro dia esta solução foi filtrada e o volume do balão foi ajustado com água deionizada.

2. Hidróxido de sódio $10 \%, \mathrm{p} / \mathrm{v}$ - Uma massa em torno de $10 \mathrm{~g}$ de hidróxido de sódio em pastilhas, pesada com precisão de $0,02 \mathrm{mg}$, foi dissolvida em $50 \mathrm{~mL}$ de água deionizada contida em um béquer de $100 \mathrm{~mL}$, o qual estava em banho de gelo. Após resfriamento, a solução foi transferida para um balão volumétrico de $100 \mathrm{~mL}$ e o volume do balão foi ajustado com água deionizada. Esta solução foi armazenada em frasco de polietileno.

3. Picrato alcalino - Um volume igual a $50 \mathrm{~mL}$ da solução de hidróxido de sódio $10 \%, \mathrm{p} / \mathrm{v}$, foi transferido para um balão volumétrico de $250 \mathrm{~mL}$ e o volume do balão foi ajustado com a solução de ácido pícrico 1\%, p/v. Esta solução foi utilizada no mesmo dia da sua preparação.

4. Creatinina, $500 \mathrm{mg} / \mathrm{L}$ - Uma massa aproximadamente igual a $126,30 \mathrm{mg}$ de creatinina-PA foi dissolvida em $50 \mathrm{~mL}$ de solução de ácido clorídrico $0,1 \mathrm{~mol} / \mathrm{L}$, 
contida em um balão volumétrico de $250 \mathrm{~mL}$. Ao balão, contendo a solução, foi adicionado $0,1 \mathrm{~mL}$ de tolueno, $\mathrm{PA}$, como preservante $\mathrm{e}$, o volume do balão foi ajustado com solução de ácido clorídrico $0,1 \mathrm{~mol} / \mathrm{L}$. Esta solução foi armazenada em frasco de vidro e mantida em geladeira.

5. Creatinina, $20 \mathrm{mg} / \mathrm{L}$ - Transferiram-se $20 \mathrm{~mL}$ da solução de creatinina, $500 \mathrm{mg} / \mathrm{L}$, para um balão volumétrico de $500 \mathrm{~mL}$. Ao balão volumétrico foi adicionado $5 \mathrm{~mL}$ de solução de ácido clorídrico $0,1 \mathrm{~mol} / \mathrm{L}$ e 2 gotas de tolueno. $\mathrm{O}$ volume do balão foi ajustado com água deionizada. Esta solução foi utilizada no mesmo dia da sua preparação.

\section{Procedimento}

1. Em um balão volumétrico, $1 \mathrm{~mL}$ de urina foi diluída para $250 \mathrm{~mL}$, com água deionizada.

2. Uma alíquota de $5 \mathrm{~mL}$ da urina diluída foi transferida para um tubo de ensaio. À esta alíquota adicionou-se $2,5 \mathrm{~mL}$ de picrato alcalino.

3. A solução foi agitada e, em seguida, foi colocada em um banho termostatizado a $40^{\circ} \mathrm{C}$, se onde deixou a reação ocorrer até a formação de uma coloração alaranjada,.

4. Preparou-se uma solução, que serviu de branco, paralelamente às amostras, adicionando-se $2,5 \mathrm{~mL}$ de picrato alcalino em $5 \mathrm{~mL}$ de água deionizada.

5. A absorbância das soluções foi medida a $525 \mathrm{~nm}$. As amostras foram medidas logo após a adição dos reagentes.

6. Uma curva analítica foi construída a partir da solução padrão de creatinina, de maneira a se obter soluções com concentrações finais correspondentes a 0,$5 ; 1,0$; 2,$0 ; 3,0 ; 4,0$ e $5,0 \mathrm{mg} / \mathrm{L}$ de urina. 
Apêndice II - QUESTIONÁRIO E FICHA DE CONTROLE DAS AMOSTRAS DE URINA

1 - Questionário entregue aos doadores de amostra

\section{ATENÇÃO}

ESTE QUESTIONÁRIO TEM POR OBJETIVO FORNECER INFORMAÇÕES IMPORTANTES PARA O PROJETO: INDICADORES BIOLÓGICOS DE EXPOSIÇĀO AO BENZENO DETERMNADOS NA URINA (QUÍMICA ANALITTICA - IQ - USP)

As amostras devem ser mantidas em geladeira até o momento da entrega!

\section{(:) AGRADECEMOS A SUA COLABORAÇÃO! :)}

Amostra $n^{\circ}-$

Data da coleta: $1+1$

horário da coleta: : h

Sexo: $\square \mathrm{M} \square \mathrm{F}$ Idade: anos Profissão:

Fumante: $\square$ SIM $\square$ NÃO Consumo médio de cigarros: cigarros / dia

Convive com fumante? $\square$ SIM $\square$ NÃO Quantas horas por dia? horas

Utilizou algum medicamento nas últimas 48 horas? $\square$ SIM $\square$ NÃO Quais?

OBSERVAÇŌES: (Relate aqui experiências de contato direto com o benzeno, atuais ou passadas) 
2- Ficha de controle das amostras

referência:

idade:

anos

amostra número:

data da coleta:

hora da coleta:

sexo: $\square \mathrm{M} \quad \square \mathrm{F} \quad$ não fumante $\square \quad$ fumante passivo $\square \quad$ fumante $\square$ cigarro / dia

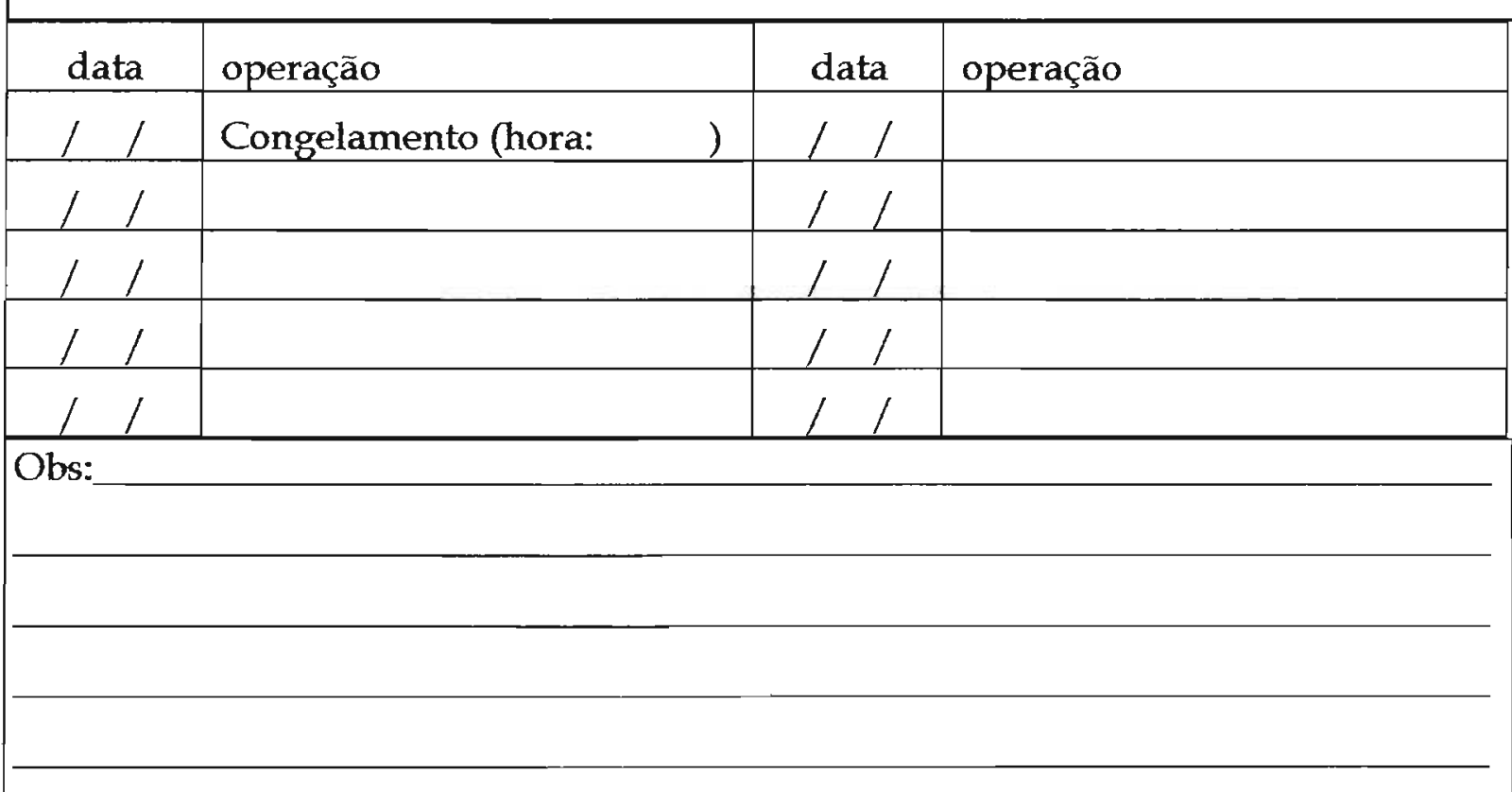

